\title{
Arroyo de los Muertos and Other Prehistoric Terrace Sites Along the Rio Grande, Laredo, Texas
}

\author{
A. Joachim McGraw
}

Follow this and additional works at: https://scholarworks.sfasu.edu/ita

Part of the American Material Culture Commons, Archaeological Anthropology Commons, Environmental Studies Commons, Other American Studies Commons, Other Arts and Humanities Commons, Other History of Art, Architecture, and Archaeology Commons, and the United States History Commons

Tell us how this article helped you.

This Article is brought to you for free and open access by the Center for Regional Heritage Research at SFA ScholarWorks. It has been accepted for inclusion in Index of Texas Archaeology: Open Access Gray Literature from the Lone Star State by an authorized editor of SFA ScholarWorks. For more information, please contact cdsscholarworks@sfasu.edu. 
Arroyo de los Muertos and Other Prehistoric Terrace Sites Along the Rio Grande, Laredo, Texas

\section{Creative Commons License}

\section{(c) (1) \&}

This work is licensed under a Creative Commons Attribution-NonCommercial 4.0 International License 


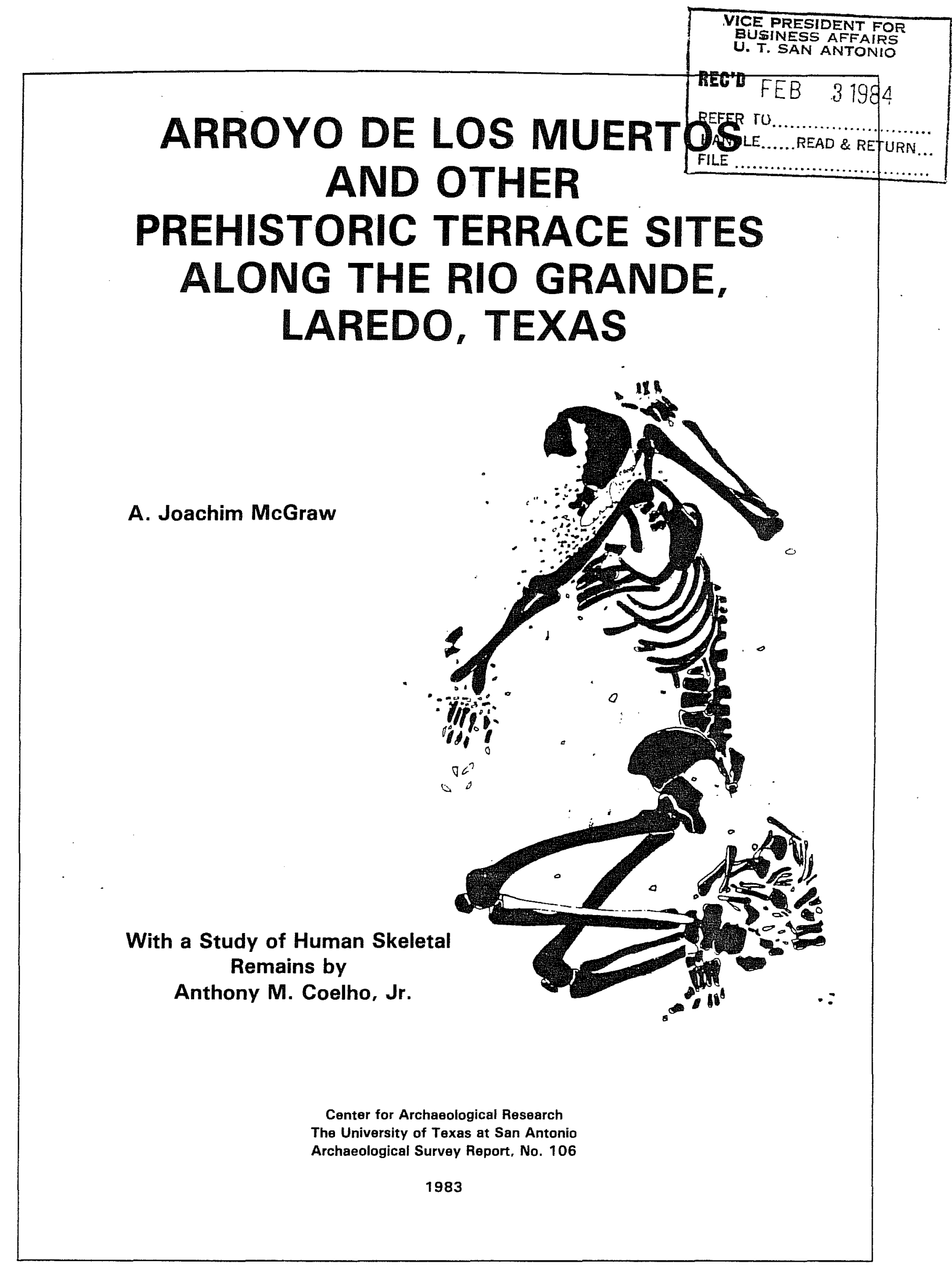





\section{ARROYO DE LOS MUERTOS \\ AND OTHER PREHISTORIC TERRACE SITES ALONG THE RIO GRANDE, LAREDO, TEXAS}

A. Joachim McGraw

With a Study of Human Skeletal Remains

by Anthony M. Coehio, Jr.

Center for Archaeological Research

The University of Texas at San Antonio

Archaeological Survey Report, No. 106 
The following information is provided in accordance with General Rules of Practice and Procedure Chapter 41.11 (Investigation Reports), Texas Antiquities Committee:

1. Type of investigation: Intensive survey and limited testing in the south Laredo area;

2. Project name: Arroyo de los Muertos;

3. County: Webb County, Texas;

4. Principal Investigator: Thomas R. Hester; Co-Principal Investigator: Jack D. Eaton; Field directors: A. Joachim McGraw and Stephen L. Black;

5. Name and location of sponsoring agency: Laredo Water Works, Laredo, Texas;

6. Texas Antiquities Committee Permit No. 230;

Published by: Center for Archaeological Research The University of Texas at San Antonio ${ }^{(1}$ San Antonio, Texas 78285 


\section{ABSTRACT}

During early 1980, personnel from the Center for Archaeological Research, The University of Texas at San Antonio, were involved in intensive survey and limited testing operations at archaeological sites in a proposed pipeline right-of-way along the Rio Grande, Webb County, Texas. Eight terrace sites, located just south of the city of Laredo, were investigated to determine potential eligibility for nomination to the National Register of Historic Places and for selection as State Historical Landmarks. Both historic and prehistoric cultural materials were identified at these sites including the remains of two previously unrecorded prehistoric burials. 


\section{TABLE OF CONTENTS}

ABSTRACT

LIST OF FIGURES

$i j i$

LIST OF TABLES

INTRODUCTION

ARCHAEOLOGICAL BACKGROUND

Previous Research . . . . . . . . . . . . . . . . 3

Chronology ..................... . . 4

Summary ...................... 8

ENVIRONMENTAL SETTING .................. 9

Geology and Geomorphology ................... 9

Biota ..................... 10

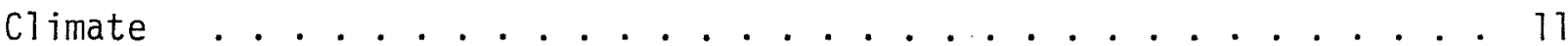

RESEARCH DESIGN AND METHODOLOGY ................ 11

SITE INVESTIGATIONS . . . . . . . . . . . . . . . . . 14

41 WB $12 \ldots \ldots \ldots \ldots$. . . . . . . . . . . . . . . 14

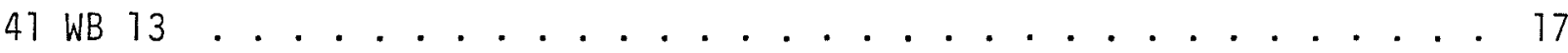

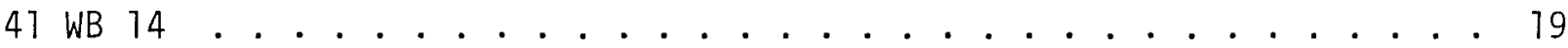

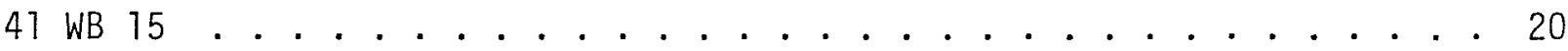

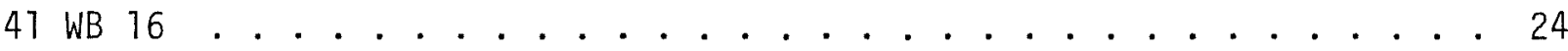

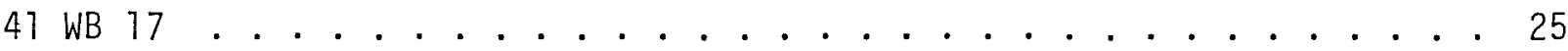

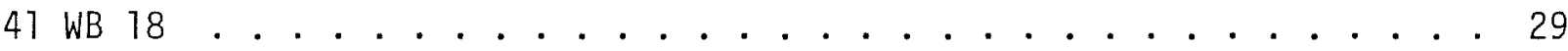

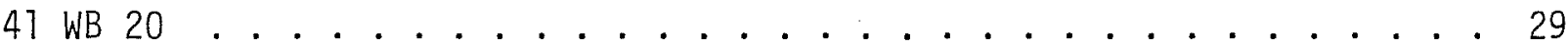

Burial 1................... . . 36

Burial 2................... . . 41

Evaluation of Skeletal Materials (Anthony M. Coelho, Jr.) . . 42

Corridor Area . . . . . . . . . . . . . . . . 45

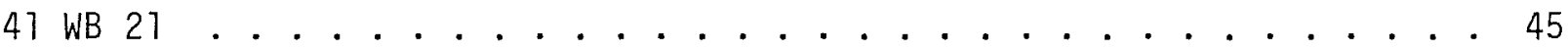

CULTURAL MATERIALS ................... 46

Projectile Points .................. . . 46 46

Bifaces and Unifaces .................. 56

Tools Classified by Identifiable Working Edges . . . . . . . . 71

Lithic Debris . . . . . . . . . . . . . . . . . . 75

Ground Stone Materials . . . . . . . . . . . . . . . 80

Bone and Shel1 Artifacts . . . . . . . . . . . . . . 80

Prehistoric Ceramics . . . . . . . . . . . . . . . 83 
Historic Cultural Materials . . . . . . . . . . . . . . 85

Burned Sandstone Rock Clusters . . . . . . . . . . . . . . 88

SUMMARY OF INVESTIGATIONS .................. . . 91

RECOMMENDATIONS ......................... 94

ACKNOWLEDGMENTS . . . . . . . . . . . . . . . . . 95

REFERENCES CITED ..................... . . 96

\section{LIST OF FIGURES}

1. General Location of the Study Area . . . . . . . . . . . . . . . 2

2. Riparian Environment Along the Rio Grande . . . . . . . . . . 10

3. Testing Methodology for the Laredo Water Works Project . . . . . . 12

4. Location of Backhoe Trenches at 41 WB 12 . . . . . . . . . . 16

5. Location of Backhoe Trenches and Excavation Units at 41 WB 13 . . . . . . . . . . . . . . . 18

6. General Location of Site 41 WB 14 . . . . . . . . . . . . . . 21

7. Location of Backhoe Trenches and Excavation Units at 41 WB 15 . . . . . . . . . . . . . . 22

8. Location of Backhoe Trenches at 41 WB $16 \ldots 25$

9. Location of Backhoe Trenches and Excavation Units

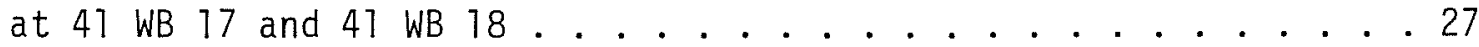

10. Summary of Trench Deposits (calcium carbonate laminae, associated charcoal flecks, and scattered cultural

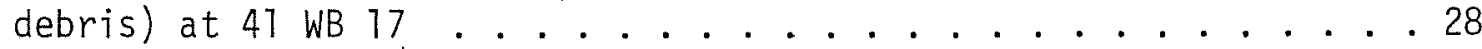

11. Location of Backhoe Trenches and Excavation Units

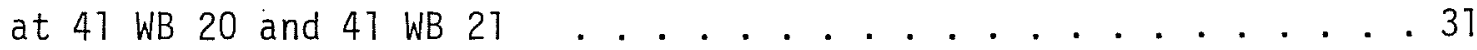

12. Summary of Trench Deposits (scattered cultural

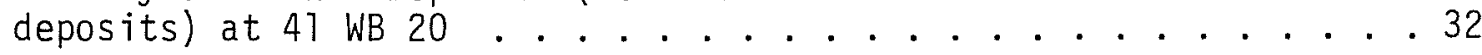

13. Profile of Backhoe Trenches 21 and 22 at 41 WB 20 . . . . . . 33

14. Profile of Backhoe Trenches 23 and 24 at 41 WB 20 . . . . . . . . 34

15. Composite Backhoe Trench Profile (estimated, scattered layers of cultural materials) of 41 WB 20 . . . . . . 35

16. 41 WB 20: Burial 1 . . . . . . . . . . . . . 37

17. 41 WB 20: Sku17 I1lustration ............... 38

18. 41 WB 20: Burial 1, Wrist I17ustration ............ 39

19. 41 WB 20: Burial 1, Infant ............... 40

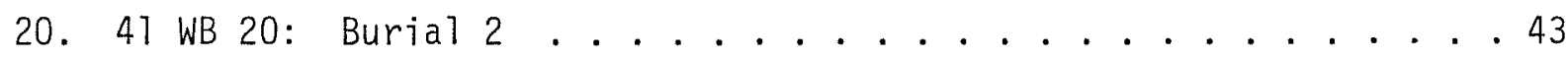


21. Projectile Points ................. . . 50

22. Projectile Points .................... 53

23. 41 WB 15: Proximal Projectile Point Fragments ........ 54

24. Composite Histograms of Morphological Biface Groups . . . . . . 57

25. Biface Groups ......................... 59

26. Biface Groups ....................... 62

27. Biface Groups ...................... 65

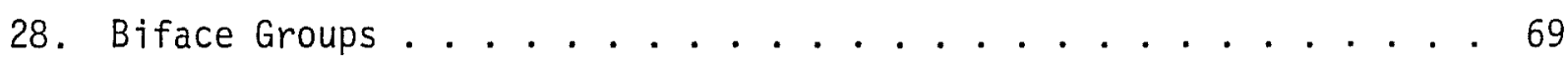

29. Composite Bifaces . . . . . . . . . . . . . . 72

30. Composite Bifaces . . . . . . . . . . . . . 73

31. Distribution of Working Edge Angles, Composite Bifaces . . . . 74

32. Comparison of Morphological Biface Groups

with Working Edge Angles . . . . . . . . . . . . 76

33. Collected Cores . . . . . . . . . . . . . . . 78

34. Ground Stone Materials . . . . . . . . . . . . . . 81

35. She11 Artifacts from Buria1 1, 41 WB $20 \ldots \ldots$. . . . . 82

36. Prehistoric Ceramic Sherds . . . . . . . . . . . . 84

37. Collected Historic Materials . . . . . . . . . . . . . 87

38. Total Count of Burned Rock Materials, by Site and Cluster . . . . 89

39. Total Weight of Burned Rock Materials, by Cluster . . . . . . . 90 


\section{LIST OF TABLES}

1. Summary of Subsurface Operations/Testing ........... 15

2. Projectile Point Morphology . . . . . . . . . . . . . . . 47

3. Provenience of Complete Projectile Points . . . . . . . . . . . . 48

4. Biface Morphological Groups . . . . . . . . . . . . . . 58

5. Provenience of Group 1, Form 1 Specimens. . . . . . . . . . . 61

6. Provenience of Group 1, Form 2 Specimens. . . . . . . . . . . . . 61

7. Provenience of Group 2, Form 1 Specimens. . . . . . . . . . . . . 61

8. Provenience of Group 2, Form 2 Specimens. . . . . . . . . . . . 67

9. Provenience and Comments, Group 3, Form 2 Specimens . . . . . . . . . 63

10. Provenience and Comments, Group 3, Form 3 Specimens . . . . . . . . . 66

11. Provenience and Comments, Group 4, Form 1 Specimens . . . . . . . . . 67

12. Provenience and Comments, Group 4, Form 2 Specimens . . . . . . . 68

13. Summary of Biface Provenience . . . . . . . . . . . . . . . . . . 70

14. Provenience and Comments, Group 4, Form 4 Specimens . . . . . . . . . 71

15. Core Characteristics ... . . . . . . . . . . 77

16. Distribution of Lithic Debris from Hand-Excavated Units . . . . . . . 79

17. Ground Stone Provenience and Description. . . . . . . . . . . . . 80 



\section{INTRODUCTION}

During February through March 1980, the Center for Archaeological Research, The University of Texas at San Antonio (CAR-UTSA), conducted intensive survey and limited testing operations at eight prehistoric and historic occupation sites in the south Laredo area, Webb County, Texas. Under contract with the City of Laredo (1etter dated January 14, 1980, from A. A. Perez, General Manager, Laredo Water Works), CAR personnel evaluated the significance of the sites and assessed the potential impact to these cultural remains by a proposed sewer pipeline and wastewater treatment facility. All work was accomplished under the requirements set forth in the National. Historic Preservation Act of 1966, as amended, and the assessment of individual site significance was based upon potential nomination to the National Register of Historic Places as well as State Historical Landmarks. The investigations were carried out under Texas Antiquities Committee Permit No. 230. Dr. Thomas R. Hester, Director, CAR-UTSA, was the Principal Investigator, and Jack D. Eaton, Associate Director, was Co-Principal Investigator of the project. The field work was carried out under the overal1 supervision of Grant D. Ha 77, Acting Assistant Director of the CAR-UTSA. The field crew directed by Stephen L. Black and A. Joachim McGraw, consisted of Tom Miller, Cecil Peel, and Curtis Dusek.

The investigated archaeological sites, located on upper terraces of the Rio Grande (Fig. 1), were first identified by D. Fox and H. Whitsett (1979), archaeologists for the Texas Department of Water Resources (TDWR), during a preliminary survey in 1979. The sites were generally characterized by extensive zones of occupation sometimes a kilometer or more in length. Survey activity was primarily conducted along a proposed pipeline route and at the ca. 20 -hectare (50-acre) location of the future plant site. Survey results indicated that soil deposits in most areas exceeded five meters, and cultural deposits more than a meter in depth were noted in arroyo walls. Fox and Whitsett (1979) decided that several of the sites were potentially eligible for the National Register of Historic Places and might meet the requirements for State Historical Landmark status.

A total of seven known and two previously unidentified sites was studied during the course of the current investigations. Primary concerns of the testing operation were (1) to accurately appraise the surface and subsurface cultural remains at these sites; and (2) to formulate specific recommendations for any future mitigation.

Because of the extremely large occupation areas, mechanical excavation techniques, employing the use of a backhoe furnished by the Laredo Water Works, were utilized to obtain subsurface cultural data. The application of backhoe trenching greatly facilitated the timely and successful completion of the field work.

During the course of the field work at the proposed location of the wastewater treatment plant, two separate prehistoric burials were unexpectedly encountered. The burial finds are significant because of the scarcity of prehistoric mortuary remains along the Rio Grande and the general lack of cultural knowledge of aboriginal groups in south Texas. Detailed descriptions of the burials, artifact collections, and discussions of the prehistoric sites are presented in the following pages. 
This page has been

redacted because it

contains restricted

information. 


\section{ARCHAEOLOGICAL BACKGROUND}

The prehistory of southern Texas (Hester 1975a) is poorly defined, and specific information on the wide-ranging cultural diversity within the region is often lacking. This report will briefly summarize past research and will discuss the accepted (but still somewhat tentative) chronological sequence as it is understood today.

\section{Previous Research}

Archaeological research of the southern Texas region is a recent phenomenon that has its roots in the early 20th century. A. Anderson, a civil engineer from Brownsville, Texas, first investigated prehistoric remains in Cameron County and northern Tamaulipas, Mexico. His work from 1908-1940 helped define the coastal-related Brownsville cultural complex (focus) of the Rio Grande delta area (Anderson 1932). Work continued in the delta, but it was not until 1947 that MacNeish presented the first major publication that discussed various archaeological components of northeastern Mexico and far southern Texas. MacNeish $(1947: 1,2)$ described four cultural complexes: Abasolo, Repelo, Los Angeles, and Diablo. The Abasolo complex, widespread in Tamaulipas, extended northwestward into Texas and was considered to stratigraphically overlie the Repelo complex and underlie the Brownsville focus.

Contemporaneous with MacNeish's work, J. C. Kelley (1947:104) suggested a "Monte Aspect of the Balcones Phase." Kelley's definition included the Repelo and Abasolo complexes presented by MacNeish. Further regional comparisons were a 7 so attemped by T. N. CampbelT (1947) and A. T. Jackson (1940).

Research during 1930-1950 continued to define the region's socio-geographical prehistoric cultural affinities, al though the actual descriptions were often based on materials from poor or surface contexts (Mallouf, Baskin, and Killen 1977).

The first major project involving survey, testing, and excavation was initiated during the Falcon Reservoir project in Zapata and Starr Counties (Krieger and Hughes 1950; Aveleyra 1951; Hartle and Stephenson 1951; Cason 1952; Jelks 1952, 1953). Krieger and Hughes (1950:24) suggested that cultural remains over a long temporal span reflected cultural continuity, with very little change for thousands of years.

Suhm, Krieger, and Jelks (1954) provided the first widely accepted terminology for cultural groups and chronological associations. The southern Texas region was subdivided into the Coastal area and the Southwest division. Suhm, Krieger, and Jelks' (1954) observations during this time were supplemented by MacNeish's (1958) work in far northern Tamaulipas where Archaic components and five moreor-less contemporaneous cultural complexes were defined: the Catán, Panuco, Las Flores, Barril, and Brownsville. 
In 1971, J. Parker Nunley (1971) reevaluated the Archaic stage within the (southwest Texas) Falcon Reservoir area and suggested a diversified entity. Other work in the early 1970s included Brown (1972), Hester (1976), Prewitt (1974), Hall and Grombacher (1974), Nunley and Hester (1975), and Hester (1975b).

More recently, archaeological work in southern Texas has been spurred by federal cultural resources guidelines and by the expansion of contract archaeology. A few of the studies in recent years include Lynn, Fox, and O'Malley (1977), Ha 11, Black, and Graves (1982), Hester (1971, 1972a, 1972b, 1972c, 1975a, 1975b, $1975 \mathrm{C}, 1977)$, and Ma1louf (1975). Archaeological research with in and surrounding Webb County includes Shiner (1969), Ha11 (1973), Peavy (1971), Bass and Hester (1975), Ivey, Med1in, and Eaton (1977), Ma11ouf, Baskin, and Killen (1977), Fox and Uecker (1978), and Fox and Whitsett (1979). For a more detailed and comprehensive discussion of southern Texas archaeology, the reader is referred to Mallouf, Baskin, and Killen (1977) and Hester (1980).

\section{Chronology}

Suhm (1960) divided the prehistory of south Texas into four distinct periods: the Paleo-Indian, the Archaic, the Late Prehistoric, and the Historic. The earliest of these, the Paleo-Indian period, is part of a much wider cultural tradition that occurred throughout much of North America ca. 9200-6000 B.C. Associated with big-game hunting and gathering, Paleo-Indian projectile points are usually represented in the southern Plains by Clovis, Folsom, Plainview, Golondrina, and Angostura dart points. Paleo-Indian manifestations in south Texas are relatively rare, but such a component may be located at the La Perdida site in Starr County (Weir 1956:59-78; Newton 1968).

Hester (1976, 1981) defines two cultural adaptations for south Texas: a maritime and a savannah adaptation. A maritime adaptation is found along the south Texas coast, where archaeological evidence indicates less frequent group movement than farther inland and involves a subsistence regime based largely on coastal resources with possibly occasional use of nearby prairie resources. A savannah adaptation reflects the utilization of the interior grasslands and riparian zones. The considerable diversity and broader dispersal of archaeological remains in these areas suggests that, because of localized adaptations to areas of "high resource density" and "low resource density, "prehistoric groups occupying the interior were more mobile (Hester 1981). Floodplain living sites acted as base camps for hunting and foraging into terrace and upland areas. The savannah subsistence regime was probably dominated by white-tailed deer and also included rabbit, turtle, turkey, fish, freshwater mussel, and snail. Ethnohistoric accounts of historic Indians suggest that plant foods were also a highly important resource (Hester 1976).

The prehistoric chronological sequence for the south Texas region in this report follows the periods described by Hester (1980) and Story (1980): Paleo-Indian, Archaic, and Late Prehistoric. 
Prehistoric Background

Paleo-Indian Period (approximately 9000-6000 B.C.)

The early Paleo-Indian period in south Texas may be represented by two major cultural traditions which reflect the adjustments of early humans to differing environmental conditions within the region (Hester 1980). The Plains-related tradition is represented by scattered finds of Clovis and Folsom-fluted points. There is also evidence of the Small Projectile Point tradition of northeastern Mexico, which may have influenced development in south Texas (Hester 1980:134136). Later in the Paleo-Indian period, numerous lanceolate and stemmed dart. points including Plainview, Golondrina, Angostura, Meserve, Milnesand, Lerma, and Scottsblu66 (Weir 1956; Hester 1968, 1969) occur. Clear Fork gouges may also have originated at this time (Hester 1976).

Broad-spectrum hunting and gathering of post-Pleistocene plants and animals were apparently practiced (Hester 1981). Subsistence and settlement patterns of these early peoples are thought to have centered at first around such biotic resources as the bison and deer or antelope; but eventually the emphas is on hunting lessened, and the orientation was largely toward food collecting (Hester 1980:142).

Archaic Period (ca. 6000 B.C.-A.D. 1000 or later)

With the increase of human populations and the advent of a drier, warmer environment due to the Altithermal in the western United States, prehistoric 1 ifestyles in south Texas changed (Hester 1980:146). Little is known about the transition from the Paleo-Indian period to the Archaic, also known as the PreArchaic by Hester (1980) and others, but within 1000 years the hunting and gathering lifestyle was considerably refined. Specific technologies for hunting and seasonal scheduling for plant gathering developed; the size of the group and its movements around the area were more closely controlled by this subsistence regime. Preferred campsites were often reused over milienia (Hester 1980).

Hester (1976) suggests that the Archaic cultural sequence in south Texas may parallel the Nogales, Repelo, Abasolo, and Catan complexes defined for northeastern Mexico by MacNeish (1958). The Archaic period is characterized by the use of similar tool forms for thousands of years, i.e., the atlatl, or spearthrower; various dart points including Abasolo, Catán, Matamoros, Desmuke, Carrizo, Langtry, Frio, and Ensor; the Clear Fork tool; choppers; side and end scrapers including the Nueces scraper; manos and metates; and hammerstones. Sharp-edged flint flakes were also used for various cutting tasks. Wooden tools were probably used as well (Hester 1980).

The Olmos triangular biface, which is common along Los 01 mos Creek in Duval County, may have originated late in the Archaic. Shafer and Hester (1971) suggest that these tools may have functioned as scrapers. The bit of the tool is usually resharpened, and burins are usually present on the corners of the bit. Olmos bifaces are concentrated in a band about 70 to 80 miles wide from western Kleberg County to central Webb County (Shafer and Hester 1971). 
Late Prehistoric Period (ca. A.D. 1000 to European contact)

The Late Prehistoric includes significant technological changes with the introduction of the bow and arrow and widespread use of ceramics. The period is well represented along the coast. The Rockport complex on the central and south central Texas coast is characterized by various stemmed arrow points, asphaltumpainted sandy paste ceramics, and a core blade technology (Campbe11 1960; Hester and Shafer 1975). The Brownsville complex in the Rio Grande delta area includes a shell-working industry, triangular arrow points, possible ceramics, trade contact with northern Mexico, and cemetery sites (MacNeish 1947, 1958; Hester 1969). No complexes have been defined for the interior, although Perdiz, Scallorn, and Fresno points, as well as bone-tempered plainware pottery, are common (Hester and Hill 1971). The cultural inventory also includes clifoton points and small side-notched specimens, crude ovate to triangular bifaces, end scrapers, flake perforators, laterally retouched blades, bone awls, manos, grooved stones, bone beads, and stone pipes (Hester 1976; Lynn, Fox, and O'Ma1ley 1977).

Late Prehistoric sites tend to be oval rather than linear as in the Archaic (Hester and Hil7 1975:7). They are usually concentrated on or near the present channels of large creeks and rivers or abandoned channels. Occupation sites are generally found close to riparian zones, while hunting sites are located on terraces and plains. Large amounts of lithic debris, hearths, and ash pits are common. Abundant faunal remains show an emphas is on small game such as rabbits and other rodents, as well as antelope, deer, and bison (Lynn, Fox, and 0'Malley 1977:41).

Historical Background

Historic Indian Groups

During the 16th century, most of southern Texas and northern Mexico was inhabited by smal1 seminomadic bands whose territorial ranges were directly related to their primary subsistence activity (Lynn, Fox, and 0'Malley 1977:27-28). These linguistically related groups are known as the coahuiltecos, and our knowledge of them stems largely from accounts of early Spanish travelers in the area, such as Cabeza de Vaca.

Shipwrecked with his men on the Texas coast in 1528, Cabeza de Vaca is generally believed to have traveled from the lower Guadalupe River southwestward to the Rio Grande and into the mountains of northern Mexico. Campbell and Campbell (1981) support his probable route as passing through prickly pear concentrations in the general vicinity of Alice, Texas, and possibly including portions of eastern Duval County. In his narrative, Cabeza de Vaca names 11 inland Coahuilteco groups (the Acubados, Anegados, Atayos, Avavares, Coayos, Comos, Cutalchuches, Maliacones, Mariames, Susolas, and Yguazes) who usually lived between the lower Guadalupe and lower Nueces Rivers, but moved southwest each summer to the prickly pear collecting grounds (Campbel1 and Campbe11 1981:10). Only the Mariames and Avavares are described in any detail by the Spanish explorer. 
The Mariames, among whom Cabeza de Vaca lived for about 18 months during 1533 and 1534, spent approximately nine months of each year in the area of the lower Guadalupe River near its junction with the San Antonio River. Here they gathered pecans, roots, and other plant foods. Fish, small rodents, and snakes were also important sources of food, and special hunting trips were occasionally made for deer (which evidently were not abundant in that area). Vegetation in the open prairie was often burned to control the animals' movement (Campbell and Campbel1 1981). Bison, although not mentioned by Cabeza de Vaca as a food source, provided the skins for robes, footgear, and shields (Campbell and Campbel1 1981:16-18). Stone tools, inferred by Cabeza de Vaca's descriptions; include flint flakes, knives, and scrapers, as well as digging sticks, nets, mortars, and pestles. Bows were apparently received through trade with the Avavares, when the Mariames were in the prickly pear collecting area (Campbell and Campbe11 1981:19). No mention is made of pottery (ibid.).

During the summer months, the Mariames traveled 30-40 leagues (126 to $167 \mathrm{~km}$ ) to the southwest to gather the ripe prickly pear tuna (fruit). Prickly pear fruits usually ripen in late May or early June to late August. The fruit and its juice were often consumed as picked, but Cabeza de Vaca records that the fruits were also dried in the sun for consumption during the return journey. Cabeza de Vaca also states that ceremonial activities, which went on in the winter months despite food shortages, reached a peak during the months spent in the tuna collecting grounds. An intoxicating beverage (made from the tuna?) may have been a part of the groups' dancing and feasting (Campbel1 and Campbel1 $1981: 21)$.

Cabeza de Vaca also spent about eight months (1534-1535) with the Avavares. He indicates that the winter range of this group was either in or adjacent to the summer prickly pear area, and their movements were less seasonal than that of the Mariames. According to Campbel1 and Campbel1 (1981:24), they were probably located on both sides of the Nueces River in parts of Duval, Jim Wel1s, and San Patricio Counties. Cabeza de Vaca says that these people wore little or no clothing and constructed temporary shelters of bent poles covered with mats similar to those used by the Mariames. They relied more heavily on deer as a food resource than did the Mariames and, in addition, consumed prickly pear, Texas ebony, and various roots. Cabeza de Vaca mentions that they sometimes searched for late ripening prickly pear fruits long after other groups had left the area (Campbell and Campbe11 1981:24). One other Coahui1teco group, the Venado (Spanish for "deer"), is said to have been present in the south Texas area in the 1700s (Campbel1 1976).

The Ccahuiltecan groups, pressured by the encroachment of the Apaches from the west, eventually succumbed to Spanish missionization (Lynn, Fox, and 0'Malley 1977). The precise fate of the Mariames and Avavares is uncertain, but the Venado were among several groups for which Mission San Juan Capistrano was established in San Antonio in 1731 (Campbe11 1976). By 1800, the Coahui1tecans were virtually extinct as a cultural entity due to disease, intermarriage with the Mexican population, and warfare. 
Spanish and Mexican Influence

Spanish interest in the area north of the Rio Grande was early, but not until the mid-1700s was a move made toward colonization in the area. In 1746, Don José de Escandón was named governor of the province of Nuevo Santander, which included present-day northern Mexico and southern Texas (Mallouf, Baskin, and Killen 1977). The northern boundary of the province was originally recognized as the San Antonio and Medina Rivers, but was later changed to the Nueces River. After an initial survey of the area, Escandón proposed only two settlements north of the Rio Grande, but neither materialized. Then, in 1750, the Rancho de Leon was established on the north bank of the Rio Grande across from present-day Guerrero. Several other ranches near the Rio Grande followed (ibid.).

During the 1800s, the area between the Rio Grande and the Nueces River became known as Llanos de las Mestiñas or Mustang Plain (Mallouf, Baskin, and Killen 1977). Before colonization, it was inhabited by raiding bands of Indians, Mexican bandits, and mustangers. In addition, poor soils, extremely dry weather, and disease greatly detracted from colonizing efforts. After the founding of the Republic of Mexico in 1821, colonists were encouraged to move into the area. Increased Indian raiding during the Texas Revolution caused many of the Mexican ranchers to return south of the Rio Grande, thus allowing the Republic of Texas to strengthen its claim in the area (Mallouf, Baskin, and Killen 1977). The lands between the Nueces River and the Rio Grande continued to be disputed for a number of years. In fact, the Mexican Congress persisted in its claim that the Nueces River was Mexico's northern boundary until the close of the Mexican-American War in 1848 (Dobie 1929).

Summary

Paleo-Indian materials and campsites are infrequently identified in southern Texas and, this has been a major shortcoming in our present understanding of regional Paleo-Indian cultures. Paleo-Indian materials range in age from ca. 9200-6000 B.C., and current evidence suggests elements of two distinct cultural traditions which may have influenced prehistoric activities in southern Texas.

The Archaic is represented by cultural materials that range in date from ca. 5000 B.C. to A.D. 1000 . Evidence suggests that this widespread (continental) cultural pattern was characterized by diversified hunting and gathering subsistence patterns adapted to local environment. Divided into Early, Middle, and Late subperiods, Archaic occupations are represented by a wide variety of dart point types and other 7ithic tools. Hester (1975a) has suggested that a distinctive Pre-Archaic period (ca. 6800-3500 B.C.) may have occurred as a transitional phase between the Paleo-Indian and Early Archaic stages.

The Late Prehistoric period (ca. A.D. 900-1000 to European contact) evidenced important technological changes in prehistoric lifeways. Bone-tempered ceramics and new lithic forms based on the introduction of the bow and arrow are reflected in the archaeological record. 
The Historic period of south Texas archaeology is represented by intrusions of Plains Indians such as the Apache and Comanche and by the arrival of Anglo-European settlers.

In summary, the cultural history of southern Texas is broadly defined, and major problems still exist in the lack of extensive and controlled investigations within most of the study area. The questions of cultural heterogeneity and inadequate definitions have combined to limit the understanding of the region's prehistory.

\section{ENVIRONMENTAL SETTING}

A brief description of the natural resources and physical characteristics of the study area is necessary for a better understanding of the prehistory of the Rio Grande area; the environmental factors that influenced early inhabitants of the region were a critical factor in the adaptation, subsistence, and survival processes. For further environimental information on the southern Texas region, the reader is referred to Thornbury (1965), Johnson (1931), Chambers (1946), BTair (1950), and Bryant (1970).

\section{Geology and Geomorphology}

Much of southern Texas, including the study area, may be defined as the Rio Grande Plain region. The Rio Grande Plain encompasses most of the area of southern Texas between San Antonio and Brownsville. Basically a lowland, the Rio Grande Plain has a varied topography because of the distinctive subareas within the region. A more dissected relief is noted in the western and southwestern areas, where short, rapid streams, draining into the Rio Grande, have cut up the terrain (Fig. 2).

Generally, the Rio Grande Plain is underlain by poorly consolidated sediments that date from Cretaceous to recent periods (Shimer 1972:7). During the Late Tertiary, the sea withdrew toward its present coastline and exposed these deposits, including Upper Eocene and Lower Miocene formations containing large volumes of volcanic ash and Late Pliocene formations of gravel, sand, and silt. Erosion has lowered much of the land surface, leaving a few hills capped with Quaternary age ancient stream gravels, sand, and silt (Creel et al. 1979). Late Tertiary age Uvalde Gravels exist in the study area and include such siliceous stone materials as chert, jasper, and quartzite. The locations of Uvalde Gravels on slopes and hilltops may have provided a major source of lithic raw material for prehistoric peoples (Betancourt 1977).

Soils within the study area consist of nearly level to undulating alluvial silty sands and soils characterized by at least 30\% clay of vertisol nature. Major soil associations include Catarina, Monte11, and Jimenez and are described as cracking (dry) clayey soil, loamy, and shallow to moderately deep over indurated caliche (Godfrey and McKee 1973).

Soils within the prehistoric site areas are of the Lagloria series (formerly classed in the Alluvial Great Soil Group): coarse, silty, mixed, river-associated 


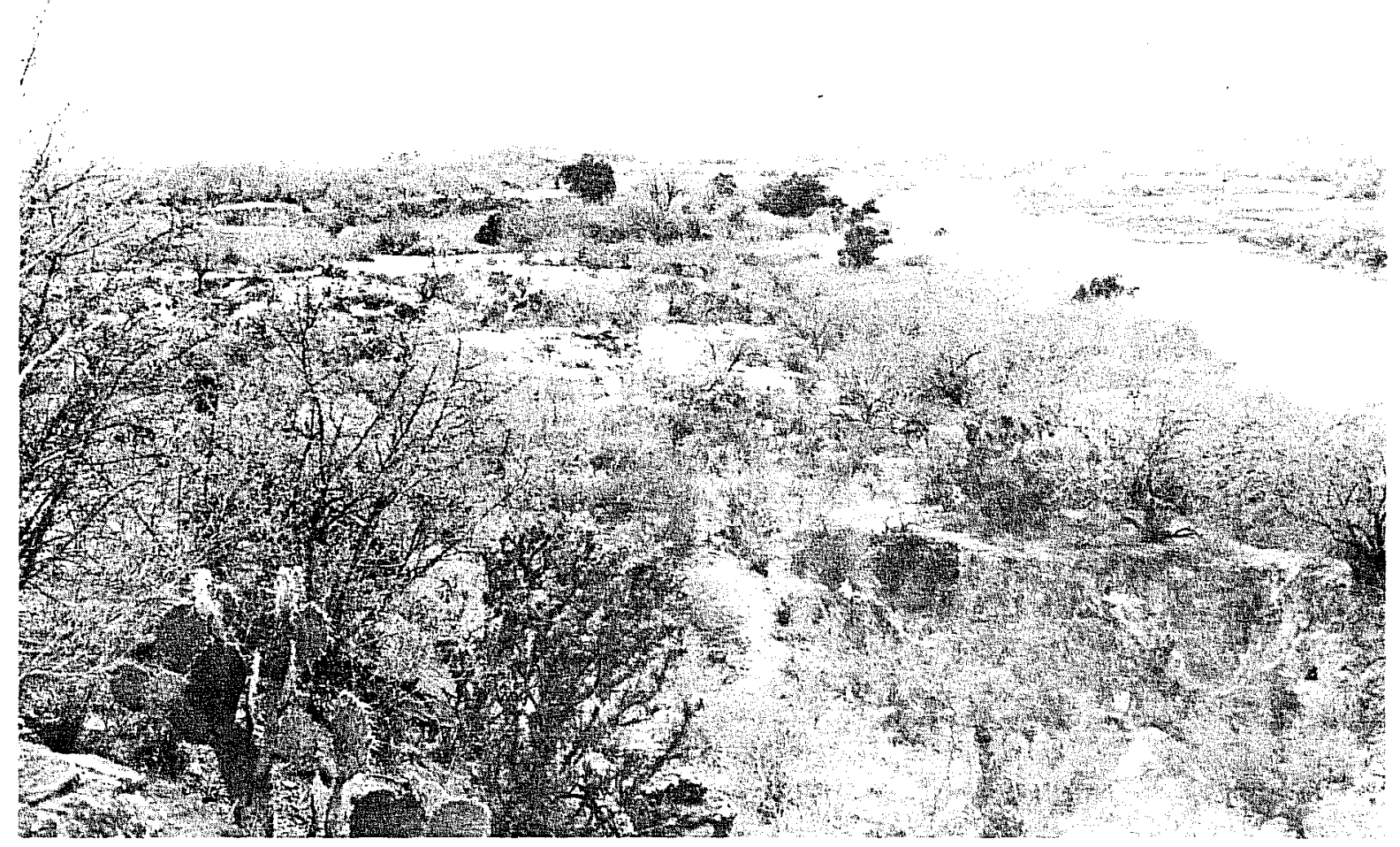

Figure 2. Riparian Environment Alang the Rio Grande.

materials of hypothermic origins. Soils are light brownish gray, calcareous, silty loam. The A Horizon has weak structure and includes films and threads of calcium carbonate with little change to a depth of ca. two meters. Lagloria soils have gradients of usually less than one percent. These soils no longer receive sediments from stream overflows except in rare cyclonic storms. Just east of the sites, soils of the Copita series are deposited. Copita soils are composed of fine, sandy, calcareous loam and overlie weakly to strongly cemented sandstone (R. Sanders and W. Gabriel, Soil Conservation Service [SCS], personal communication). In the context of this report, the Copita series differs from the Lagloria series most importantly by the differences in native vegetation (Nunley 1971:20) that they support (see Biota).

\section{Biota}

The flora and fauna of the south Texas region have generally been classed into the Tamaulipan Biotic Province by Blair (1950:102-105). Dominant vegetation is composed of thorn brush, and its density is directly related to the availability of moisture. Plant species include Mimosa and Acacia, granjeno (Celtis pallida), mesquite (Prosopis juliffora), Tignum vitae (Porliera angustifolia), tasaji110 (opuntia leptocaulis), prickly pear (Opuntia lindheimeri), Condalia, and Castela (B1air 1950:103). 
Larger trees, such as live oak, pecan, elm, cottonwood, and cypress, are common along river floodplains. Upland vegetation is generally dominated by grama, buffalo grass, mesquite grasses, and mesquite. Upland shrubs include guayacan or soapbush, blackbrush, huisache, black persimmon, whitebrush, yucca, sangre de drago, prickly pear, lotebush, and other cacti. Vegetation in the immediate vicinity of the study area includes such native grasses as trichloris, tanglehead, cottontop, bristlegrass, lovegrass, tridens-hooded windmillgrass, and pink pappusgrass. Woody vegetation includes large mesquite trees, spiny hackberry, Texas ebony, guayacan, and blackbrush (R. Sanders and W. Gabrie], SCS, personal communication).

Richardson (1980) suggests that the great increase in cattle and sheep ranching during historic and modern times caused major changes in the distribution of flora and fauna. Because of reduced fuel on the prairie and control by settlers, prairie fires, once a common occurrence, became less frequent. The chaparral of southern Texas became a thorn forest of mesquite brush, as did the central and southern Gulf Coast region of Texas.

Blair (1950) suggests that the vertebrate fauna of the Tamaulipan Biotic Province is composed of "Neotropical" species and of some of the neighboring Texan- and Kansan-related biotic province fauna. Sixty-one mammal species, 36 snake species, 19 species of lizards, three urodele species, two species of land tortoise, and nine anuran species (frogs and toads) have been reported.

For further information on the biota of the region, the reader is referred to Blair (1950) and Holdsworth (1972).

\section{Climate}

The Rio Grande Plain area is a semiarid lowland characterized by a mild climate and a long growing season. Thornwaite (1948) has described the present climate as thermal and semiarid. Others suggest that the interior region has a mesothermal steppe climate with a dry season in the winter, while the coastal margins have occasional tropical or desert years and multiseasonal precipitation. Mean annual precipitation in Webb County ranges from ca. 17-27 inches; mean annual temperature is $\mathrm{ca} .74^{\circ} \mathrm{F}$.

\section{RESEARCH DESIGN AND METHODOLOGY}

Research strategy for intensive survey and limited mechanical and hand testing during the Laredo Water Works project was based upon a systematic investigative process designed to maximize data collection efforts. The object of the Phase II testing operation was threefold: (1). to define more accurately cultural. resources within the path of future modifications; (2) to assess the historical and cultural potential of these resources; and (3) to recommend further mitigation or no further work (Fig. 3).

To accomplish the study, several primary objectives were formulated: (1) the recognition of inter- and intrasite patterns; (2) an accurate estimate of the 


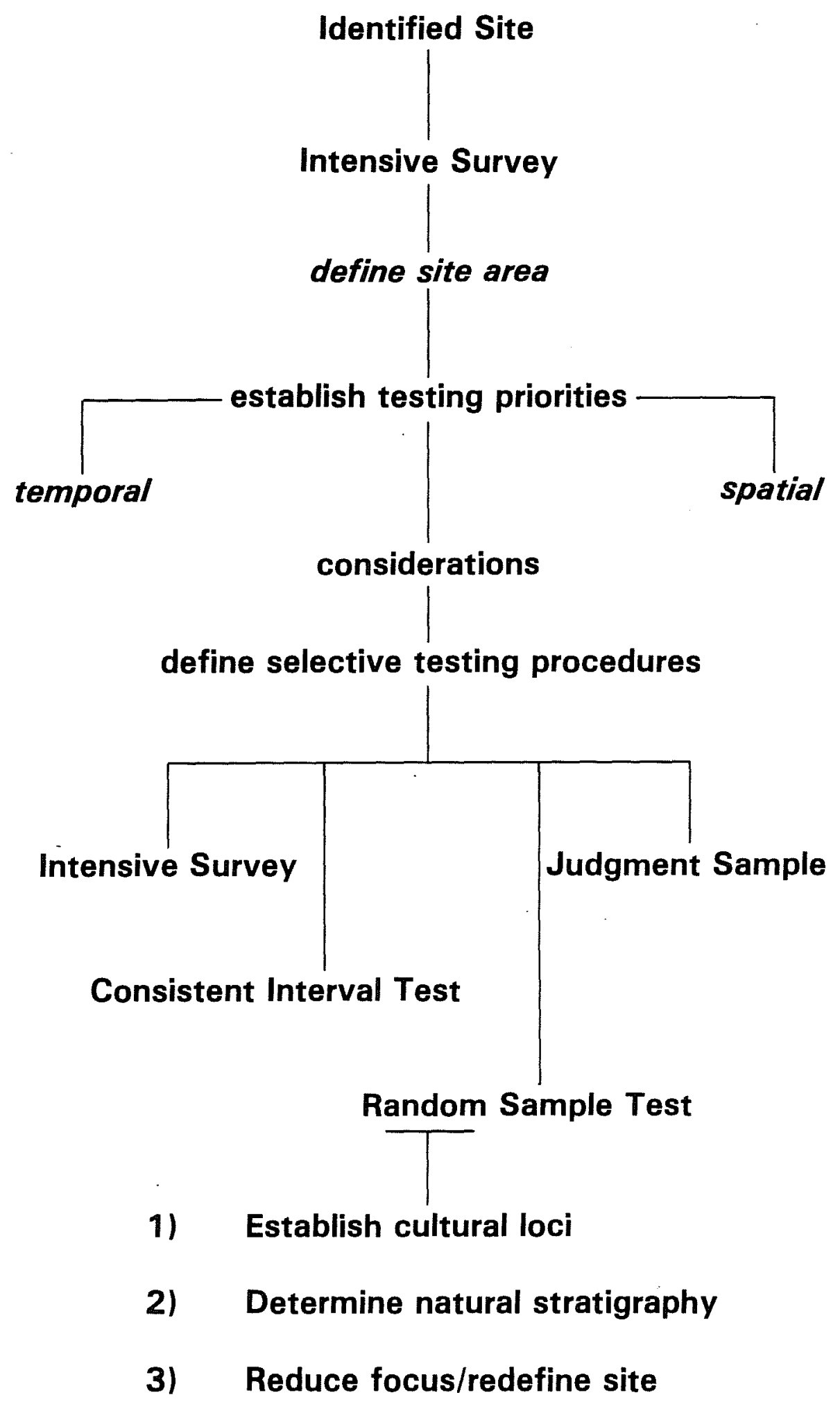

Figure 3. Testing Methodology for the Laredo water works Project. 
horizontal and vertical distribution of cultural resources; and (3) the identification of important environmental elements that may interrelate to past occupation and subsistence activities.

Site testing was preceded by intensive surveys to locate features, artifact concentrations, and site limits. After a determination of surface conditions, each site was reconsidered in the light of technical and material priorities such as mechanical limitations, project scheduling, etc. For each site, a selective testing procedure was established by a careful review of four elements: (1) intensive survey; (2) the application of judgment sampling; (3) consistent interval testing; and (4) random sampling site testing. While all of these were considered, only intensive survey and consistent interval testing were chosen as feasible designs, based on the extensive site areas and the time available. Consistent interval testing by mechanical excavation was based upon inspections that had previously revealed few or no surface artifact concentrations. Dependent upon site dimensions and available field time, a backhoe excavated a series of approximately equidistant backhoe trenches to reveal subsurface boundaries and limits of cultural deposits. As subsurface concentrations were noted, a smaller series of intervaled trenches was excavated to define the actual limits of these features. For most site areas, consistently intervaled trenching was complemented by judgment sampling on the part of the field team, in addition, particular areas of topographic relief or interest were often trenched to test for cultural materials.

The trenching interval was flexible and quite dependent upon site size, accessibility, and time constraints. Generally, at each locality where the trenching was employed, spacing varied from between 20 to 60 meters. The extremely large site areas made total site testing impractical, and testing was concentrated along and around the proposed pipeline route and plant site, as defined on the plan maps furnished. Interval testing worked best in relatively level areas with light to moderate brush and worked less well in areas of poor accessibility and dense brush. In the latter cases, mechanical interval testing was supplemented by intensive survey and hand-excavated units. For further discussion of the practicality of sampling techniques, the reader is referred to Jelks (1975:23-24) and Redman (1974).

After a determination of cultural 10ci, artifact deposits were noted in relation to natural. stratigraphy, and the focus of the testing was redirected either toward further delineation of cultural deposits or toward continuation of overall site testing (Fig. 3).

Data on newly discovered sites were recorded on standard site survey forms used by the CAR-UTSA, and provenience of all collected materials was recorded on field forms and collection bags. Matrix samples were taken at several feature locations and were later analyzed for content using chemical flotation techniques. Al1 field notes, laboratory analyses, and other pertinent data are currently on file at the CAR-UTSA. 


\section{SITE INVESTIGATIONS}

Seven recorded sites, 41 WB 12, 41 WB 13, 41 WB 14, 41 WB 15, 41 WB 16, 41 WB 17, 41 WB 18, and two previously unidentified sites, 41 WB 20 and 41 WB 21 , were investigated. The last two are buried sites discovered by backhoe trenching in the vicinity of the proposed plant site location. All nine sites are located on upper river terraces along the eastern margins of the Rio Grande. Alluvial, fine-grained, sandy soil deposits at the sites were more than two meters in depth, and the sites were often overgrown with thorn brush.

The location of 41 WB 15 was unique in that it was situated adjacent to and on the margins of an extensively eroded, large sandstone outcropping. The site is located atop a steep rise, well over $100 \mathrm{~m}$ above the river channel, and afforded the most attractive lookout point among the surveyed areas.

Field operations progressed smoothly with the generous cooperation of the Laredo Water Works under the direction of A. A. Perez. High winds and dust often created miniature sandstorms within the backhoe trenches, an unexpected hazard. Another incident of field work occurred when two project members inadvertently began excavating a test unit in the direct line of duck hunters from across the Rio Grande (neither ducks nor archaeologists were hit).

Detailed descriptions of individual sites are presented in the following pages. Table 1 summarizes the type and extent of subsurface excavations.

\section{WB 12}

Location: Site 41 WB 12 is located along the slopes of an upper river terrace ca. $1.3 \mathrm{~km}$ west of U.S. Highway 83 and ca. $2.7 \mathrm{~km}$ south of Saltillo Street, Laredo (Fig. 4).

Dimensions: The prehistoric site area extends ca. $0.7 \mathrm{~km}$ north to south and ca. $200 \mathrm{~m}$ east to west.

Type of Site: Light occupation (multifunctional), possibly multicomponent.

Distance from Nearest Water Source: ca. 200 meters.

Elevation: (as per USGS topographic map, 1:24,000 scale) 380-400 feet above mean sea level (ms 1 ).

Site Condition: Partially cleared. Areas not cleared are covered by tall grasses and scrub brush. Subsurface deposits on most of the site are critically damaged. Margins are heavily eroded.

Investigations: Fox and Whitsett (1979) observed a thin scatter of prehistoric chipped stone and mussel she 17 fragments exposed in eroded and otherwise disturbed areas. Mid-to-7ate 19th-century and early 20th-century artifacts were observed across the surface of the site. 
TABLE 1. SUMMARY OF SUBSURFACE OPERATIONS/TESTING

\begin{tabular}{lcccc} 
Site & $\begin{array}{c}\text { Mechanical } \\
\text { (Backhoe Trenching)* }\end{array}$ & $\begin{array}{c}\text { Hand } \\
\text { Excavations }\end{array}$ & $\begin{array}{c}\text { Unit } \\
\text { Size }\end{array}$ & Depth \\
\hline 41 WB 12 & 13 & none & -- & \\
41 WB 13 & 7 & Test Unit 1 & $2 \mathrm{~m}^{2}$ & $0-50 \mathrm{~cm}$ \\
& & Test Unit 2 & $2 \mathrm{~m}^{2}$ & $0-50 \mathrm{~cm}$ \\
& & 1 Shove1 Test & $50 \mathrm{~cm}^{2}$ & $0-50 \mathrm{~cm}$
\end{tabular}

41 WB $14 \quad$---Intensive survey (due to poor accessibility and very limited site area)

\begin{tabular}{|c|c|c|c|c|}
\hline 41 WB 15 & 14 & Test Unit 1 & $2 \mathrm{~m}^{2}$ & $0-50$ \\
\hline \multicolumn{2}{|l|}{ Rockshelters } & 2 Shovel Tests & $50 \mathrm{~cm}^{2}$ & $0-75$ \\
\hline 41 WB 16 & 4 & none & & \\
\hline \multirow[t]{4}{*}{41 WB 17} & 14 & Test Unit 1 & $2 m^{2}$ & $0-60$ \\
\hline & & Test Unit $1 A$ & $1 \times 2 \mathrm{~m}$ & $0-60$ \\
\hline & & Test Unit 2 & $2 \mathrm{~m}^{2}$ & $0-60$ \\
\hline & & Test Unit 3 & $1.5 \times 0.75 \mathrm{~m}$ & $0-60$ \\
\hline 41 WB 18 & 4 & none & & \\
\hline \multirow[t]{2}{*}{41 WB 20 and 21} & 25 & Test Unit 1 & $1 \times 2 \mathrm{~m}$ & $0-80$ \\
\hline & & Test Unit 2 & $2 \mathrm{~m}^{2}$ & $0-80$ \\
\hline
\end{tabular}

* Number of trenches. 
This page has been

redacted because it

contains restricted

information. 
Testing operations by CAR personnel utilizing a backhoe, revealed few prehistoric cultural materials, either in the subsurface or on the surface. Only scattered flakes were exposed on the extensively eroded western site boundaries. Further backhoe trenches were excavated in or along the pipeline route at the site. Subsurface structure throughout the site consisted of loose, light brown, homogeneous, silty sands to depths of over three meters. A shallow recent topsoil. was noted in most areas to a depth of ca. $12 \mathrm{~cm}$. Backhoe Trenches 4, 5, and 6 all uncovered a thin layer of cultural materials ca. 10-15 cm thick at an approximate depth of $150 \mathrm{~cm}$ below the surface. Burned sandstone, charcoal flecks, mussel shell fragments, Rabdotus shel1s, and 1 ithic debris comprised the cultural remains. Backhoe Trenches 7 and 8 revealed a similar layer at $120-125 \mathrm{~cm}$. A thin layer of charcoal and slightly discolored soil was found in Backhoe Trench 10 at $\mathrm{ca} .150 \mathrm{~cm}$ below the surface.

Backhoe trenching at the site took the form of $6 \times 2 \times 3-m$ (length, width, and depth) trenches and revealed meager cultural deposits to the floor of the excavations (ca. $3 \mathrm{~m}$ ). No evidence of historical occupations was noted. Modern surface refuse may have been the result of long-term, casual dumping. No prehistoric chronologically diagnostic artifacts were recovered from the site. No further work is recommended in this area.

\section{WB 13}

Location: The site occupies the upper eastern terraces along the Rio Grande ca. $950 \mathrm{~m}$ west of U.S. Highway 83 and $2.1 \mathrm{~km}$ south of Saltillo Street (Figs. 1, 5). Deep arroyos separate 41 WB 13 from 41 WB 12 to the south and 41 WB 14 to the north.

Dimensions: ca. $1 \mathrm{~km}$ north to south and $0.2 \mathrm{~km}$ east to west.

Type of Site: Light to moderate multifunctional (multicomponent?) activity zone.

Distance from Nearest Water Source: less than $200 \mathrm{~m}$.

Elevation: $390-400$ feet ms 1 .

Site Condition: A modern farming complex now occupies portions of the prehistoric activity area, and an apparently recent (20th-century) sandstone-1ined acequia runs from a pumping station to the northern site margins. Vegetation is uncleared in some portions and is dominated by moderate to dense mesquite and smaller thornbush.

Investigations: Fox and Whitsett (1979) recovered a sma11, expanding stemmed (Ensor-like) dart point from the surface near the southern end of the site and suggested possible buried components within the locality.

The dense vegetation and eroded topography of 41 WB 13 made backhoe trenching difficult. Nonetheless, a total of seven trenches was excavated (Fig. 5). The central site area had been extensively damaged by the modern farm complex; 
This page has been

redacted because it

contains restricted

information. 
only the extreme northern and southern margins remained relatively undisturbed. Intensive survey revealed mussel shell concentrations along both the northern and southern site boundaries adjacent to large arroyos. Three backhoe trenches were excavated in the southern location, revealing evidence of buried deposits. Backhoe Trench 1 revealed only light and scattered charcoal flecks to depths of three meters, but Backhoe Trench 2 profiles showed at least two distinct cultural activity zones. Backhoe Trench 1, at a depth of $38-50 \mathrm{~cm}$ below the surface, and Backhoe Trench 2, at 200-210 cm, were both characterized by burned sandstone, charcoal flecks, and mussel she 11 fragments in compacted soil matrices. Little apparent color change was noted between the cultural levels and the homogeneous, sterile sands.

A smaller cluster of mussel shell fragments eroding from the nearby surface also suggested a possible third and much more recent site component.

Backhoe Trench 3 reflected evidences of a lower activity zone at ca. $140-220 \mathrm{~cm}$, with a thin scatter of charcoal flecks throughout this level. Backhoe Trench 4 showed charcoal mottling in the wall profiles, with occasional Rabdotus and burned sandstone occurring to the floor of the trench ( $3.5 \mathrm{~m}$ below the surface).

On the basis of materials recovered from trenching in the southern portion of the site, two separate $2-\mathrm{m}^{2}$ units were hand excavated directly in the proposed pipeline route. Test Unit 1, located five meters east of Backhoe Trench 1 , was dug to a depth of $50 \mathrm{~cm}$ below the surface. All earth was screened through 1/8inch wire mesh. Few cultural materials were collected. Level $4(40-50 \mathrm{~cm})$ revealed only 13 small chips and flakes of chert.

Test Unit 2, excavated adjacent to Backhoe Trench 2, uncovered a small beveled triangular point and associated cultural debris at $32 \mathrm{~cm}$. Further excavations eventually revealed a small circular burned sandstone cluster ca. $44 \mathrm{~cm}$ in diameter, located at a depth of $35 \mathrm{~cm}$ below the surface. Matrix samples were collected from the interior of the basin-shaped feature, and excavations continued to $50 \mathrm{~cm}$. No other features and very few pieces of $1 \mathrm{ithic}$ debris were noted.

Bàckhoe Trenches 5, 6, and 7 in the northern section of the site revealed very thin layers of mixed charcoal flecks and mussel shell fragments but no other subsurface deposits. A surface concentration of 1 ithic tools was discovered around the arroyo margins in the extreme northern section of the site. A careful inspection of the arroyo walls revealed eroding sandstone hearths exposed along the walls, ca. one to two meters below the surface. Although stone chips and burned rock clusters were noted along the arroyo walls, the extensive erosional activity precludes any major buried deposits. The modern modifications at 41 WB 13, combined with the lack of subsurface materials discovered during testing, indicate that no further. work is warranted at this location.

41 WB 14

Location: Site 41 WB 14 consists of an isolated, eroded terrace remnant in the midst of an otherwise low-lying arroyo floor. The remnant, located just north 
of 41 WB 13, thrusts well over $10 \mathrm{~m}$ above the surrounding topography. The site is located ca. $700 \mathrm{~m}$ west of U.S. Highway 83 and $1.4 \mathrm{~km}$ south of Saltillo Street in Laredo (Fig. 6).

Dimensions: ca. $1350 \mathrm{~m}^{2}$.

Type of Site: Possibly a hunting-overlook site and/or very light occupation site.

Distance from Nearest Water Source: ca. $40 \mathrm{~m}$. A sma 11 creek in the arroyo floor runs toward the Rio Grande (ca. 200-300 m distant).

Elevation: $360-380$ feet ms 1 .

Site Condition: The site is extremely eroded, but a very 1 imited area remains intact. Fox and Whitsett (1979) observed mussel shell fragments and chipped stone eroding from the upper portions of the site. A small, serrated arrow point fragment was also recovered by them.

Investigations: The inaccessibility of the terrace remnant made any efforts at backhoe trenching infeasible. The terrace remnant was instead intensively surveyed, with hand excavations considered as an alternative to mechanical means if significant deposits were observed. After a careful examination of the steep eastern and western slopes and the small crest (1ess than two meters wide), no cultural evidence was discovered. Several widely scattered mussel she11 fragments were observed on the lower eroding slopes of the remnant, but none were noted in situ. Thin threads of calcium (described by Fox and Whitsett [1979] as 1aminea) were discovered in some walls of the terrace remnant. While these threads are generally associated with cultural deposits, by themselves they reflect only thin zones of soil leaching possibly caused by prolonged exposure to surface elements (Glen Evans, personal communication). A $50-\mathrm{cm}^{2}$ shovel test was dug along the crest of the remnant to a depth of $50 \mathrm{~cm}$. No artifacts were noted, and the unit was considered sterile. Because of the extremely disturbed condition of the site (caused by natural erosion) and the lack of cultural materials, no further work is recommended at 41 WB 14.

41 WB 15

Location: Site 41 WB 15 is located on and also adjacent to the property owned by the Sacred Heart Children's Home. The site is situated on an elevated sandstone bluff above the Rio Grande ca. $300 \mathrm{~m}$ west of U.S. Highway 83 and ca. $1 \mathrm{~km}$ south of Saltillo Street in Laredo (Fig. 7).

Dimensions: The site is an example of an extensive multifunctional occupation zone well over $0.5 \mathrm{~km}$ in length. Distinct loci of material distributions are still discernible in the northern and southern areas. The central portion is now disturbed by a large citrus orchard, building complex, and water tank. The site extends east to west at least $250 \mathrm{~m}$. 
This page has been

redacted because it

contains restricted

information. 
This page has been

redacted because it

contains restricted

information. 
Type of Site: Multifunctional, multicomponent.

Distance from Nearest Water Source: $100-250 \mathrm{~m}$ to the Rio Grande.

Elevation: $400-420$ feet ms 1 .

Site Condition: Portions are extremely eroded, disturbed, or damaged.

Investigations: Intensive survey identified two major artifact concentrations at the northern and southern site margins. The northern locus was discovered on the eastern slopes of the upper river terrace, just north of the modern building complex. Lithic debris, several biface fragments, and fire-reddened sandstone were observed in an open, plowed field; no bone was noted.

Another prehistoric activity locus was discovered along the edges of a deep arroyo. Cultural materials included a sand-tempered prehistoric ceramic sherd (see Cultural Materials section), a Perdiz (?) arrow point, and an Abasolo, Catán, Refugio, Shumla, Early Triangular, and other unclassified dart points and fragments. Several ground stone fragments were collected. Sma17, eroded burned rock clusters were noted along the arroyo walls. Backhoe trenching just north of the central area revealed somewhat disturbed, but apparently continuing, subsurface deposits that underlie most of the bluff. Trenching indicated that the subsurface in the vicinity of the central area is most disturbed, while the northern and southern margins of the bluff are least disturbed.

A total of 14 backhoe trenches, two $50-\mathrm{cm}^{2}$ shovel tests, and one $2-\mathrm{m}^{2}$ unit was excavated in selected areas of the site. Trenches throughout the site and along the estimated pipeline route revealed very little cultural depth. Thin cultural layers composed of scattered lithic debris and charcoal flecks were observed in all trenches to depths of less than $40 \mathrm{~cm}$ below the surface. A very thin calcareous soil contact line suggesting an old eroded surface (Glen Evans, personal communication) was identified in many of the trenches at ca. $120 \mathrm{~cm}$ below the surface, but no cultural materials were associated with this surface.

The extensive amount of surface materials warranted further mitigation. Consequently, additional backhoe trenches near to but outside the actual pipeline corridor were excavated. It was hoped that this supplemental testing would contribute more information and would more accurately describe the nature of both buried and surface cultural deposits. These latter backhoe trenches revealed very little soil and cultural deposits beyond the (eastward) margins of the arroyo. A deteriorated sandstone bedrock was uncovered less than a meter below the surface in these areas.

A $2-\mathrm{m}^{2}$ hand-excavated test unit was also opened in the southern section of the site to sample the exact subsurface extent and distribution of the site's components. Excavated to $50 \mathrm{~cm}$, the unit produced a total of 3558 fragments of lithic debris, primarily small tertiary flakes and decorticate chips in the upper $30 \mathrm{~cm}$. Below $30 \mathrm{~cm}$ lithic debris and associated mussel shell fragments became almost nonexistent. No extensive layers of charcoal (as observed at other tested sites) were noted at 41 WB 15. 
In addition to subsurface testing, other activities at the site included a careful examination of two small sandstone rockshelters near the top of the steep sandstone bluff. Each shelter was ca. seven meters wide, ca. five meters high at the maximum point, and ca. five meters deep. The deteriorated sandstone materials appeared to spall easily, and a great deal of fractured sandstone was scattered in and around the shelter.

Possibly of Eocene origins (Glen Evans, personal communication), the shelters were tested by two $50-\mathrm{cm}^{2}$ shovel tests to a depth of $75 \mathrm{~cm}$. No artifacts were recovered within, adjacent to, or below the rockshelters.

The extensive occupation zone as a whole appears concentrated around the arroyo and bluff margins, except for the northern cultural locus which is curiously situated much farther eastward. Although the central site area was not tested because of the modern building complex, it is presumed that the locality of the modern structures overlies aboriginal deposits. Cultural depositions are concentrated in the upper $30 \mathrm{~cm}$ of soil, and much of this soil deposit appears eroded and/or deflated. A long span of Archaic to Late Prehistoric activity is represented, as evidenced by the variety of distinctive projectile point styles collected from the surface. Grinding slab fragments were observed throughout the site as well as large amounts of mussel shell fragments. The latter suggest mussels may have been a major subsistence resource. The panoramic view of the river channel and environs may have contributed to making this locality a preferred occupation site during prehistoric times.

The extensive disturbance of the site, combined with intensive investigations at undisturbed localities, suggests that the site is not of National Register quality. Further mitigation along this portion of the pipeline route is not necessary.

\section{WB 16}

Location: Site $41 \mathrm{WB} 16$ is situated on the property of radio station KLAR in Laredo, Texas, ca. $0.5 \mathrm{~km}$ north of $41 \mathrm{WB}$ 15. The terrace site is ca. $100 \mathrm{~m}$ west of U.S. Highway 83 and 200 m east of the Rio Grande. The sandstone bluff margins of 41 WB 15 form the southern boundaries of the site. Extensive erosional gullies and modern earthmoving activities separate it from 41 WB 17 to the north (Fig. 8).

Dimensions: A light surface scatter of materials was noted across the ca. $400 \times$ $200 \mathrm{~m}$ upper terrace. Cultural debris was observed eastward from the extensively eroded slopes to the highway.

Type of Site: Light occupation and/or multifunctional. Components unknown and/or unidentified.

Distance from Nearest Water Source: ca. $200 \mathrm{~m}$ to the Rio Grande.

Elevation: $370-400$ feet $\mathrm{msl}$.

Site Condition: Extensively eroded. 


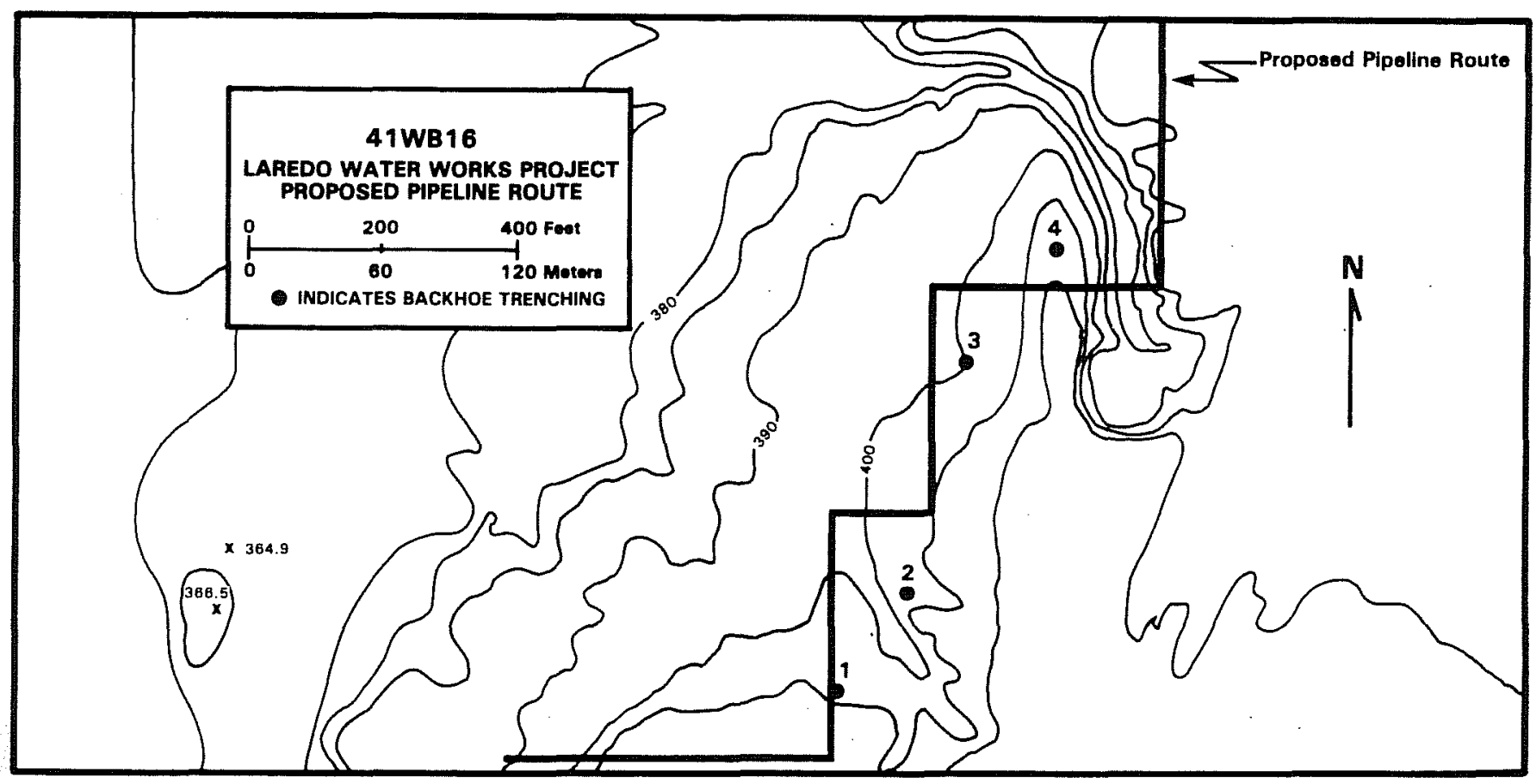

Figure 8. Location of Backhoe Trenches at 41 WB 16.

Investigations: Past work by Fox and Whitsett (1979) identified late 19th- and early 20th-century refuse scattered across much of the site. Site conditions and the impact of modern clearing and erosion could not be further assessed without subsurface testing.

Intensive survey, complemented by four backhoe trenches, suggested that this area had only been lightly occupied in prehistoric times. Only occasional firereddened sandstone rocks or $7 i$ thic debris fragments were observed. Backhoe trenching revealed a thin level of Rabdotus snail and burned sandstone ca. $1.25 \mathrm{~m}$ below the surface in an otherwise culturally sterile Backhoe Trench 1 (Fig. 8). Burned sandstone rock and a few mussel shell fragments were noted at $30-45 \mathrm{~cm}$ below the surface in Backhoe Trenches 2 and 3. No other significant deposits were observed. Several biface fragments were collected from the surface of 41 WB 16 (see Cultural Materials section). One is similar to the Nueces scraper type defined by Hester, White, and White (1969). No historical materials or features were discovered.

The lack of significant cultural deposits and the extensive erosion indicates that no further work is necessary at 41 WB 16.

\section{WB 17}

Location: The site is located on a high secondary terrace along the east bank of the Rio Grande. U.S. Highway 83 and its intersection with Saltillo Street 
in Laredo, form the eastern site boundary. A deep arroyo overgrown with tall brush separates the locality from 41 WB 18 to the north (Fig. 9).

Dimensions: Site 41 WB 17 is a linear activity zone at least $400 \mathrm{~m}$ in length. The total estimated cultural area is in excess of $450 \mathrm{~m}$.

Type of Site: Multifunctional (multicomponent?). Light to moderate occupation and/or activities.

Distance from Nearest Water Source: ca. $50 \mathrm{~m}$ to intermittent source (arroyo); distance to Rio Grande ca. $250 \mathrm{~m}$.

Elevation: ca. 400 feet msl.

Site Condition: Past investigations by Fox and Whitsett (1979) suggested that a large part of the site had previously been cleared. The vegetation now consists of tall grasses and young mesquite in the northern section. Prehistoric lithic debris, burned sandstone, and mussel shell fragments were observed along slopes in disturbed areas. A knoll at the northern portion of the site revealed mid-to-late 19th-century household materials. Possible sandstone structura? remains were observed by Fox and Whitsett (1979), although the historic component appeared to be badly disturbed.

Investigations: An intensive survey of 41 WB 17 revealed few prehistoric diagnostic artifacts. Three Abasolo projectile points were collected from the surface. No subsurface historic remains were encountered. Fourteen backhoe trenches, two 2-m $\mathrm{m}^{2}$ units (Test Units 1 and 2), and a $1.5 \times 0.75-\mathrm{m}$ unit (Test Unit 3) were excavated at the site.

Trenching revealed few significant subsurface deposits. Notes on trench deposits are summarized in Figure 10. Cultural materials were limited to a very smal1 collection of 1 ithic debris, charcoal, and occasional burned sandstone fragments. The few cultural remains observed in trench profiles thinned toward the northern portion of the site, but the surface lithic scatter increased.

A burned, fire-fractured sandstone rock feature was discovered in the north wall of Backhoe Trench 2, and a 2-m² unit was excavated adjacent to the trench to expose this feature. To fully uncover the subsurface materials, the $2-\mathrm{m}^{2}$ unit was expanded an additional one by two meters. An isolated, but intact hearthlike feature, was uncovered at a depth of $44-50 \mathrm{~cm}$ below the surface. Consisting of a very compact cluster of rocks, the feature measured $58 \times 36 \mathrm{~cm}$ along its major axis. Materials from the cluster consisted of burned, fire-reddened sandstone with friable chunks measuring $\mathrm{ca} .8-16 \mathrm{~cm}$ in length. Fill surrounding the sandstone was charcoal-ash stained with flecks and small chunks of charcoal. Most of the charcoal was observed directly under the rocks. Very few lithic materials were recovered.

A second $2-\mathrm{m}^{2}$ unit was excavated over a burned sandstone surface scatter ca. $15 \mathrm{~m}$ northeast of Test Unit 1. This unit was excavated to a depth of $50 \mathrm{~cm}$. An Abasolo-like projectile point was recovered at $2.8 \mathrm{~cm}$. A charcoal stain ca. $30 \mathrm{~cm}$ in diameter was also noted at $48 \mathrm{~cm}$ below the surface. The quantity of lithic debris recovered from this unit suggests that this level at a depth of $30-50 \mathrm{~cm}$ may be related to cultural zones identified in nearby backhoe trenches. 
This page has been

redacted because it

contains restricted

information. 


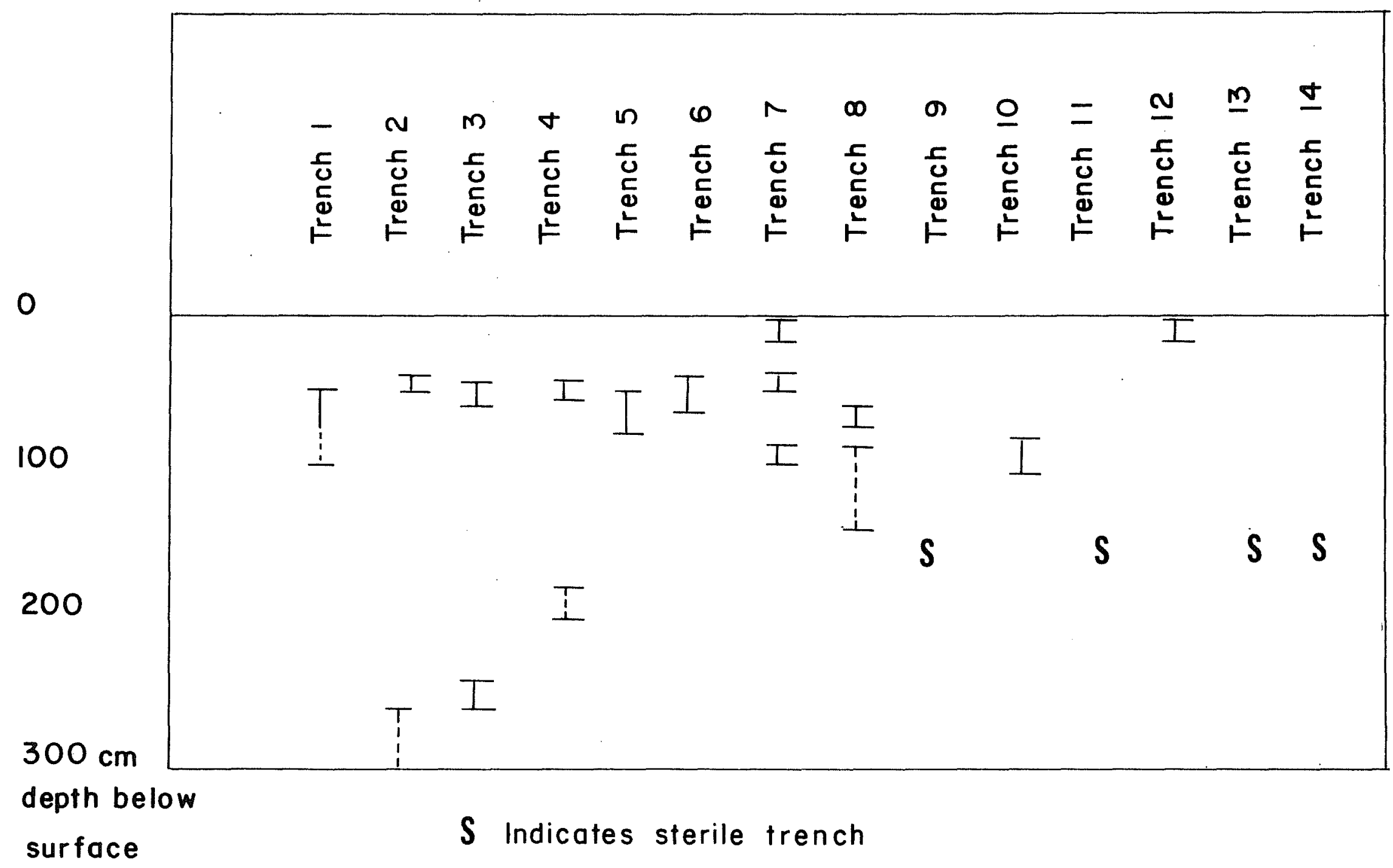

Figure 10. Summary of Trench Deposits (calcium carbonate laminae, associated charcoal flecks, and scattered cultural debris) at 41 WB 17. 
A third test unit $(1.5 \times 0.75 \mathrm{~m})$ was excavated along the arroyo wall at the northern site margins. A large charcoal concentration, measuring $75 \times 70 \mathrm{~cm}$, was discovered eroding from the arroyo wall at a depth of $75 \mathrm{~cm}$. Excavations to $85 \mathrm{~cm}$ below the surface revealed a solid charcoal and ash feature $82 \times 45 \times$ $7 \mathrm{~cm}$. Large chunks of charcoal in and around the feature imply the fire was deliberately stopped before complete incineration took place. Several corroded metal fragments were collected: one buckle, a bit of wire, and two metal grommets(?). Many small bones, including fish vertebrae and scales, were found around the feature. No other diagnostic materials were collected.

No significant features were discovered at 41 WB 17 , either by intensive survey efforts or subsurface testing. No further work is recommended at this site.

\section{WB 18}

Location: Site 41 WB 18 is situated on an eastern, upper terrace of the Rio Grande. A deep arroyo near the end of the Meadow Acres housing subdivision of Laredo forms the northern boundary. Another arroyo separates 41 WB 18 from 41 WB 17 to the south (Fig. 9).

Dimensions: ca. $200 \times 250 \mathrm{~m}$ maximum.

Type of Site: Light occupation.

Distance from Nearest Water Source: ca. $300 \mathrm{~m}$ (arroyos may have once included intermittent stream systems).

Elevation: 400 feet ms 1 .

Site Condition: Except for the western margins, the site is considerably altered by modern landfills.

Investigations: Intensive survey revealed a light scatter of burned sandstone rock, lithic debris, and deer skeletal material (D. Fox, personal communication) eroding from the arroyo walls at the site. Subsequent backhoe trenching revealed modern fill to depths of almost three meters in Backhoe Trenches 1 and 3 . The fil1, characterized by a scattering of modern refuse, such as bottle caps, glass, and metal fragments, was composed of layers of discolored, unconsolidated sands. Deposition of these materials presumably occurred as part of a sma17, modern, landfill. Backhoe Trench 2 was culturally sterile except for a burned sandstone fragment at $25 \mathrm{~cm}$ below the surface. Backhoe Trench 4, near the western site margins, revealed three thin layers of charcoal flecks at depths of $70 \mathrm{~cm}, 80-$ $90 \mathrm{~cm}$, and $110 \mathrm{~cm}$. No other materials were observed, al though one small ground stone fragment was surface collected. Because of the extensive damage to the area, no further work is recommended at this site.

\section{WB 20}

Location: The location is ca. $75 \mathrm{~m}$ north of the deep arroyo just south of the proposed sewage treatment plant and less than $20 \mathrm{~m}$ from the treatment plant's 
western boundary (Fig. 11). Prehistoric cultural remains extend northward, parallel to and outside the plant's western boundaries as defined on completed plan maps. Dimensions of the site are tentative since the site consists entirely of buried deposits (see below).

Dimensions: The actual dimensions are difficult to determine, but may extend as far as $90 \mathrm{~m}$ north to south and $50 \mathrm{~m}$ east to west. Based on profiles in adjacent backhoe trenches, the site is a minimum of $50 \mathrm{~m}$ in length.

Type of Site: Multicomponent (unidentified), multifunctional site with only thin cultural deposits characterizing most of the site.

Distance from Nearest Water Source: ca. 275-300 m.

Elevation: $370-400$ feet ms 1 .

Investigations: A total of 25 backhoe trenches was excavated in the proposed plant site area. Early trenching revealed little throughout the locality, although the southeast corner of the plant boundary (Fig. 11) contained a 1ight lithic scatter (see discussion of site 41 WB 21).

Because of the proposed modification in the plant site area, the locality was thoroughly investigated. Although most of the site area contained very thin and scattered archaeological deposits of only minimal relative significance, there were several distinct charcoal-flecked lenses revealed in Backhoe Trench 4. Additional trenching (Figs. 12, 13, and 14) to investigate these lenses revealed a buried, multizoned cultural deposit that was eventually recorded as 41 WB 20.

Several clearly defined prehistoric activity levels were identified, including an upper component noted in Backhoe Trenches 4, 21, 22, 23, and 24 at ca. 50$70 \mathrm{~cm}$. Six other separate and distinct levels of charcoal flecks, mussel she 11 fragments, burned sandstone rock, and some lithic debris were noted in these series of trenches (Fig. 15).

The chronological relationships of these levels are unidentified because of the paucity of diagnostic artifacts and other cultural materials. Each level appears only as a light to moderate reflection of activity, with the exception of Component $V$ in Backhoe Trench 21. A massive layer of charcoal-stained soil was noted along the entire seven-meter trench profile at a depth of ca. 135$170 \mathrm{~cm}$. While charcoal layers had been a common occurrence throughout the project operations, the unusual size of this feature demanded further exploration.

It must be noted that the upper cultural component levels of Backhoe Trenches $4,21,22,23$, and 24 lie immediately adjacent to and marginally within the plant site boundaries. It was decided to continue investigations at this locality because the proposed construction would destroy all cultural remains in the area, and a definable and practical assessment was required for all cultural materials within the immediate vicinity of the construction location. 
This page has been

redacted because it

contains restricted

information. 


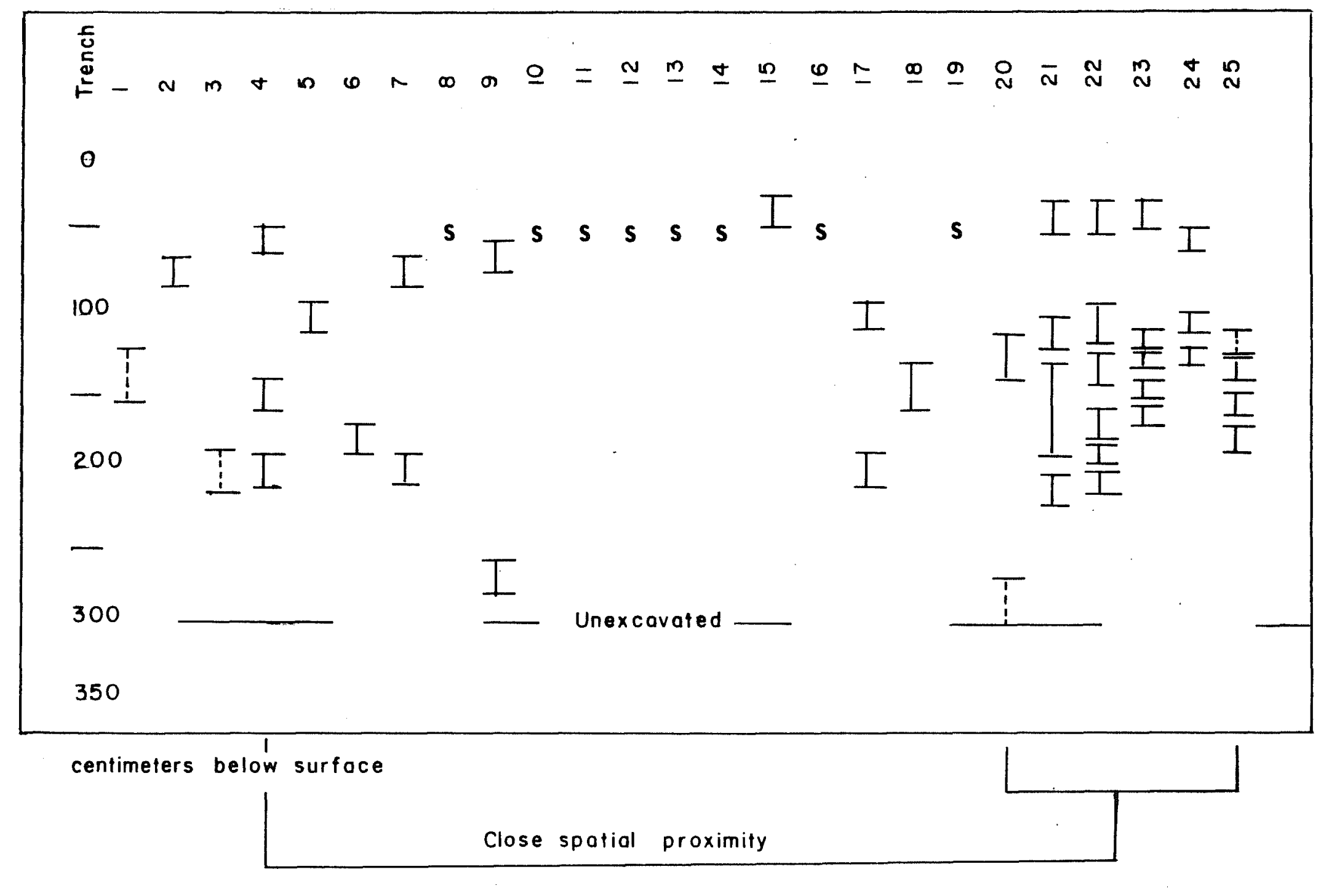

$S$ indicates sterile trench

Figure 12. Summary of Trench Deposits (scattered cultural deposits) at 41 WB 20. 


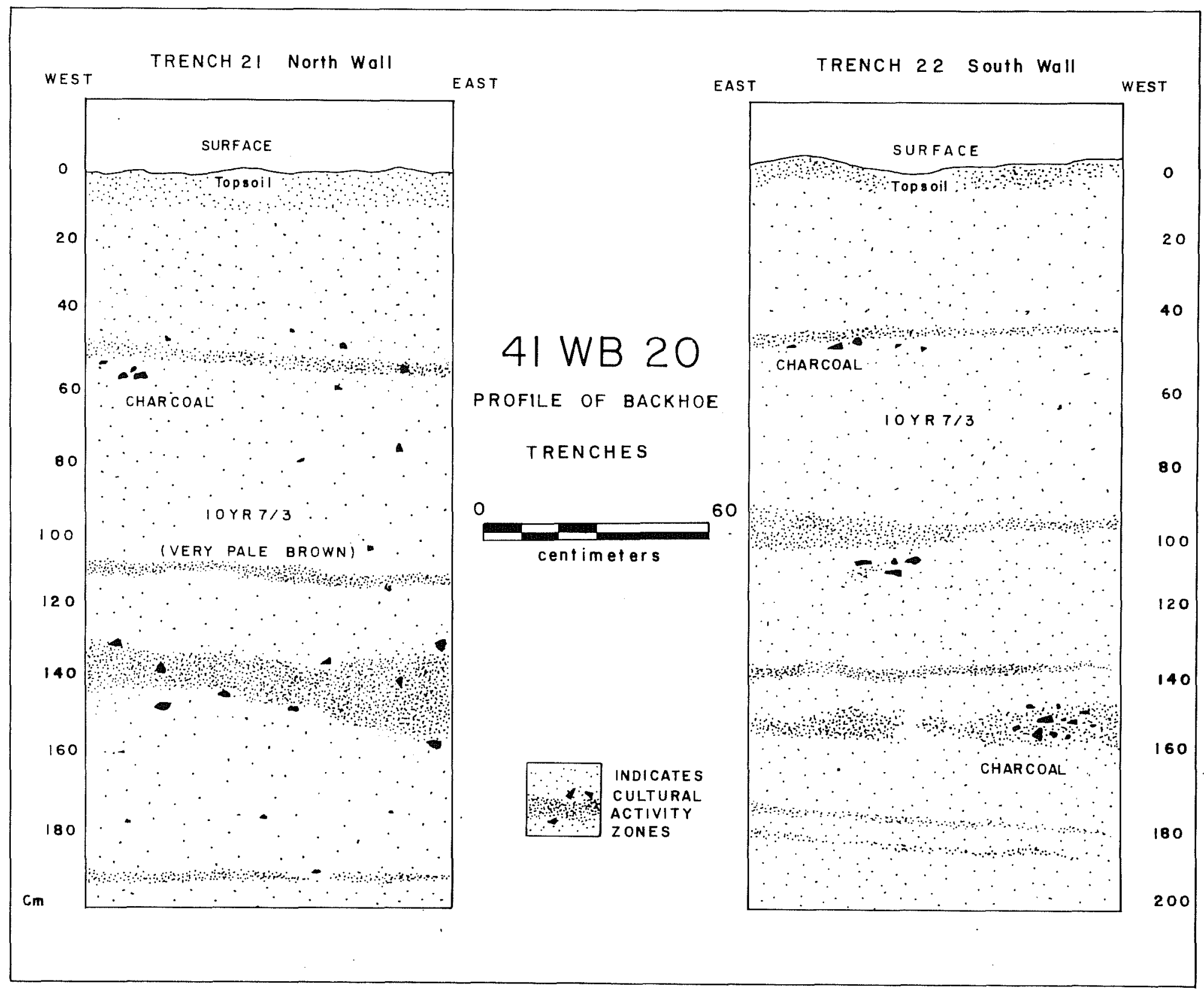

Figure 13. Profile of Backhoe Trenches 21 and 22 at 41 WB 20 . 


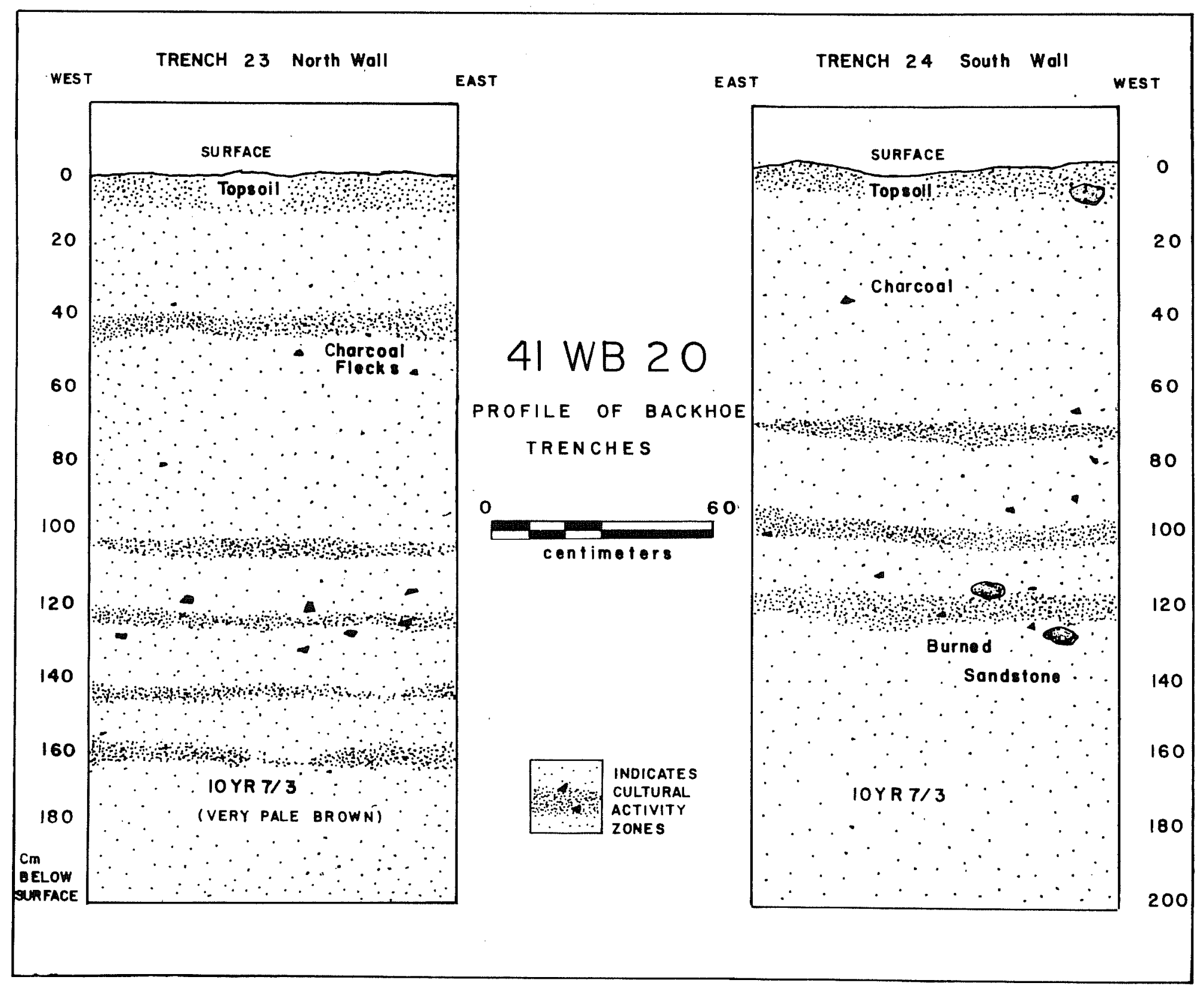

Figure 14. Profile of Backhoe Trenches 23 and 24 at 41 WB 20 . 
Conferences with Howard Gaddis, consulting engineer for the Laredo Water Works pipeline project, also confirmed an outlet corridor (unknown size at present) that would run from the western site boundaries to the Rio Grande. These factors required that further testing be conducted in the areas of subsurface cultural deposits in the immediate vicinity of Backhoe Trench 21. Since many of these cultural components were known to be below one meter from the surface, it was more profitable to backhoe excavate a $12-\mathrm{m}^{2}$ area adjacent to the south wal1 of Backhoe Trench 21 to an approximate depth of $80-100 \mathrm{~cm}$. A 2-m² unit was then hand excavated from this depth.

\section{Burial 1}

During the cleaning of loose fill from the backhoe excavated square, a large bone fragment was discovered in the southwest corner at ca. $70 \mathrm{~cm}$ below the surface. After careful troweling, several small bone beads were uncovered, and then it became apparent that portions of a prehistoric human burial lay just beyond the southwest corners of the pit.

The entire overburden earlier removed by the backhoe was painstakingly screened through 1/8-inch wire mesh for additional bone fragments and artifacts, however, only a few additional bone beads were collected. A $2-\mathrm{m}^{2}$ unit was demarcated on the original surface above the burial, and the field crew began hand excavations of the interment. During the removal of the overburden, a large, darkened soil area was noted $\mathrm{ca} .40 \mathrm{~cm}$ below the surface. It was speculated that this was the upper level of a buried pit. At ca. $70 \mathrm{~cm}$, however, the outlines disappeared. The associations, if any, of this buried pit to the burial below are unclear.

The vertical limits of the grave outline were not clearly established because of homogenous soil conditions, but the upper limits were defined at a depth of ca. $60 \mathrm{~cm}$. The burial pit appeared to intrude into several lower cultural levels (characterized by compacted soils) that contained occasional charcoal and mussel fragments.

The skeletal materials were of an adult in a semiflexed position with the femora at ca. $90^{\circ}$ and $45^{\circ}$ angles to the spine (Fig. 16). The skeleton was oriented east to west, with the sku1l facing north. Average depth of the bones below the surface was $78 \mathrm{~cm}$. Minimal posthumus shifting of bone was noted; the left rib cage was collapsed. Objects associated with the adult consisted of many smal1, tubular bird bone beads (possibly of a waterfowl) perhaps belonging to a necklace of several strands (Fig. 17). Two mussel shell pendants were associated with the necklace. A cluster of bone beads, surely once a bracelet, was found in the area of the left wrist. Grave fill was similar to surrounding soils and was distinguished only by a slightly darker color change and somewhat looser relative compaction. The vertical limits of the grave outline were not clearly established because of homogeneous soil conditions, but the outlines were clearly established at a depth of $60 \mathrm{~cm}$. The burial pit appeared to intrude into seven lower levels of compacted soils that contained occasional charcoal or mussel fragments. No other unusual burial characteristics were noted, except that the right arm was twisted behind the body (Fig. 18).

When Burial 1 was completely exposed, highly fragmented pieces of a small infant skeleton were uncovered at the feet of the adult (Fig. 19). The infant bones 


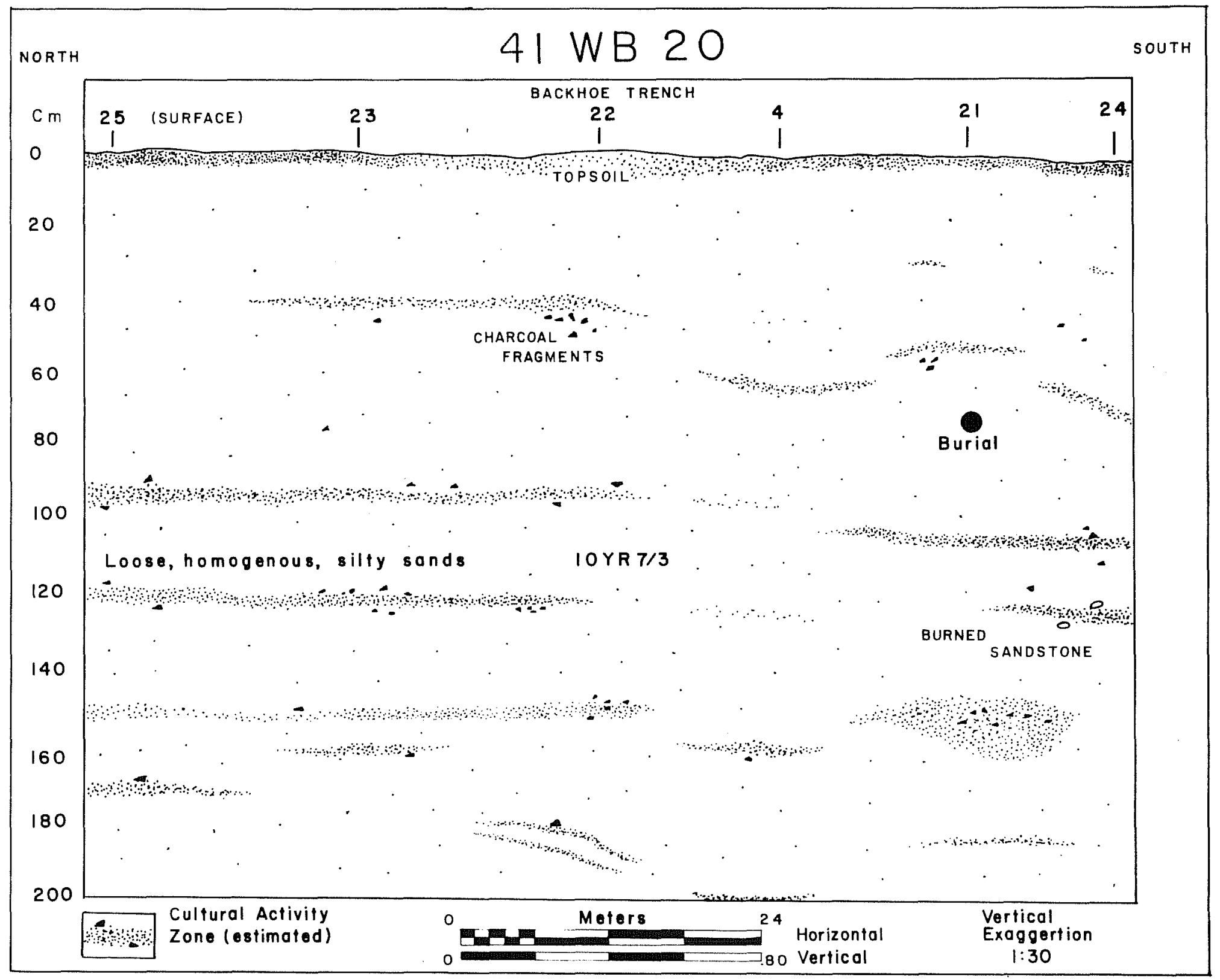

Figure 15. Composite Backhoe Trench Profile lestimated, scattered layers of cultural materials) of 41 WB 20. 


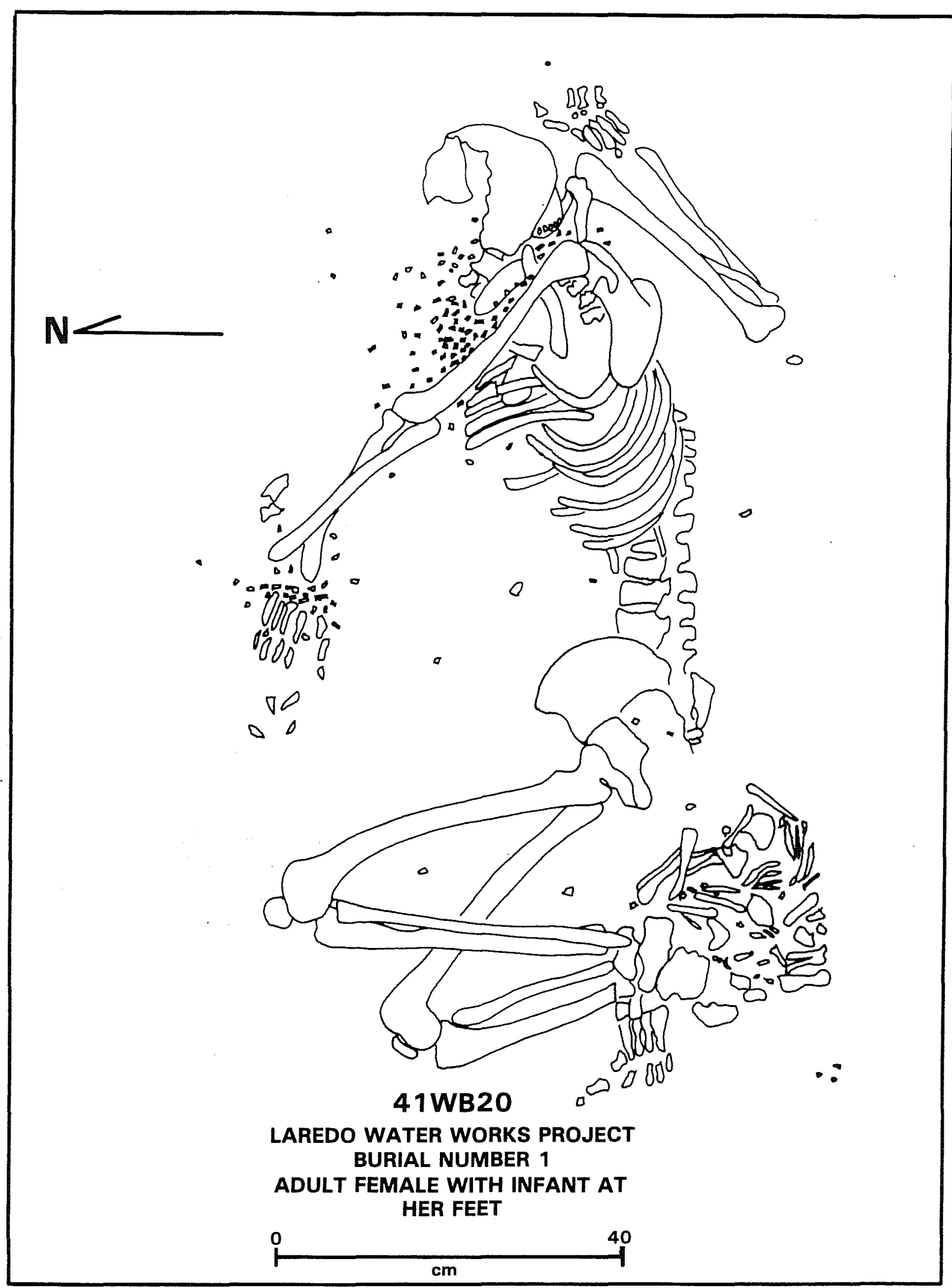

Figure 16. 41 WB 20: Burial 1. 


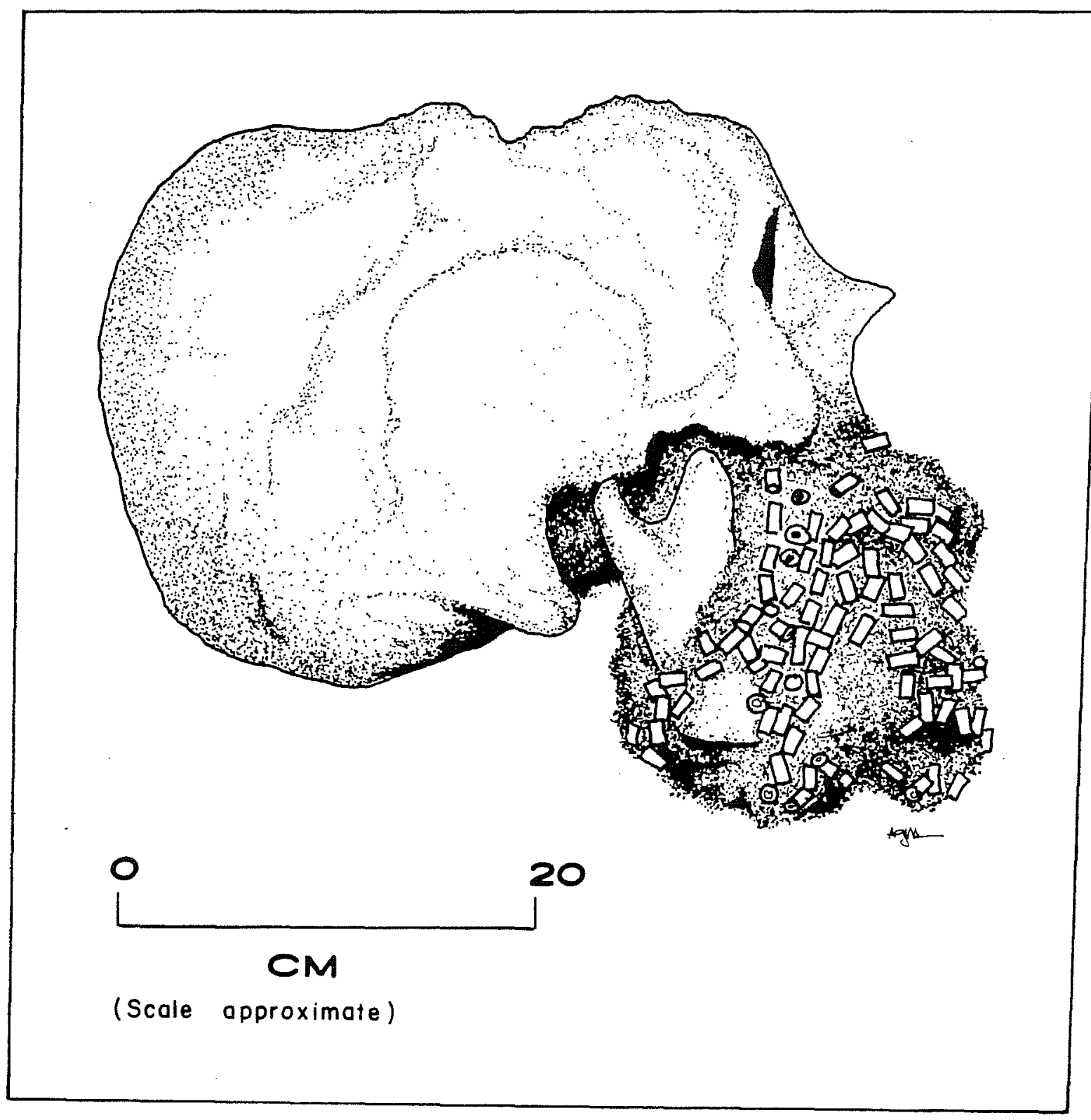

Figure 17. 41 WB 20: Skull Illustration. 


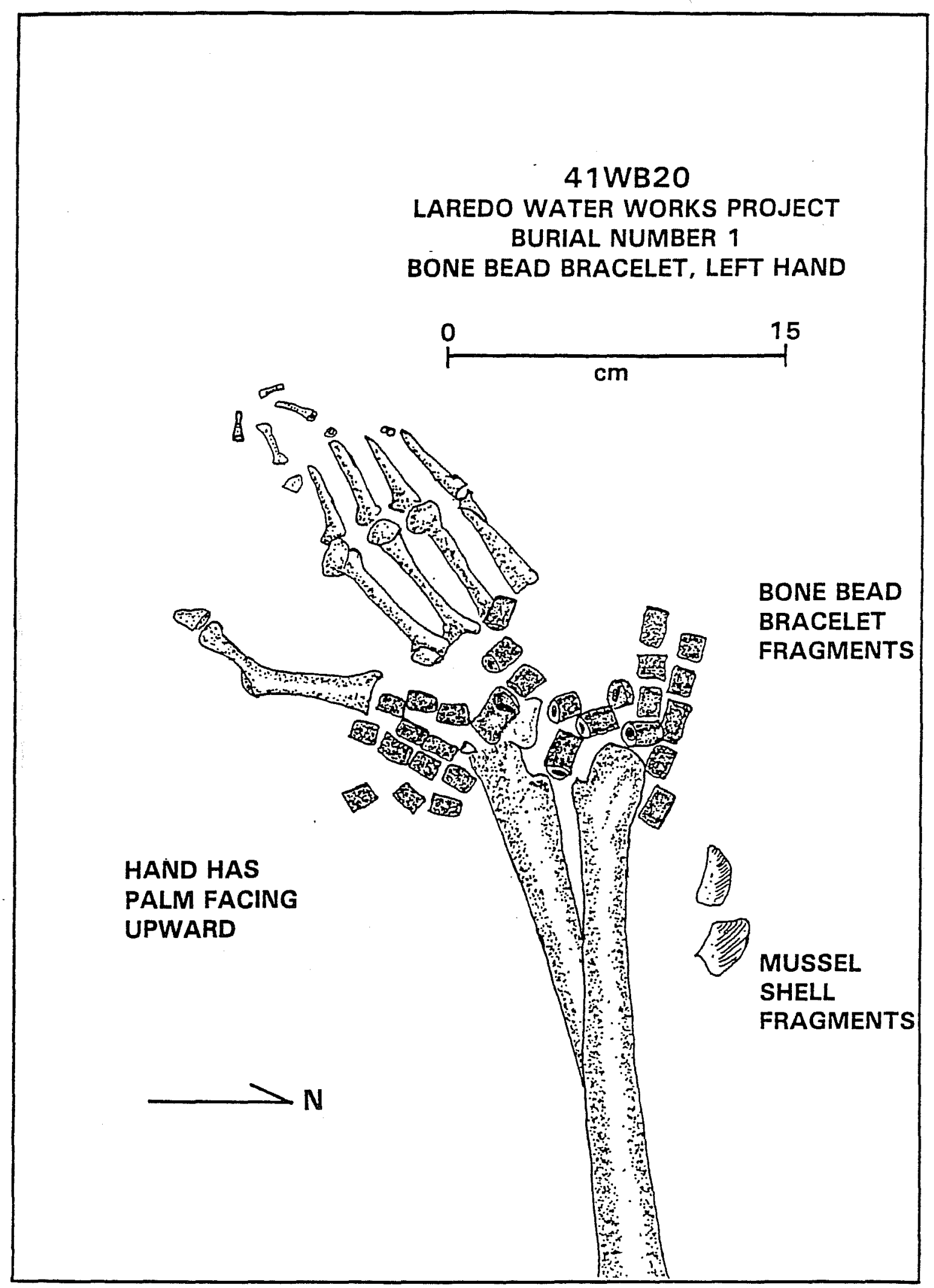

Figure 18. 41 WB 20: Burial 1, Wrist Illustration. 


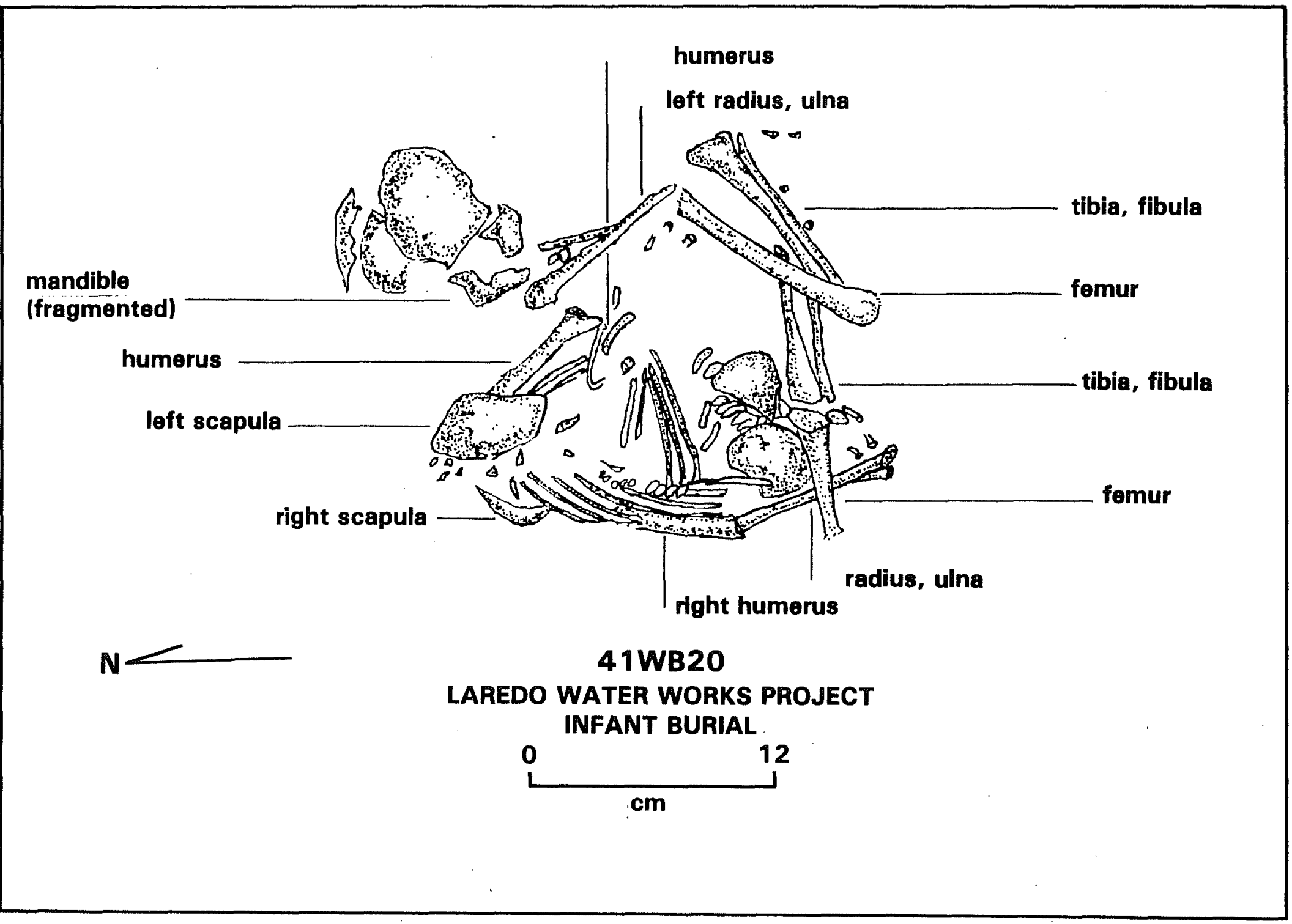

Figure 19. 41 WB 20: Burial 1, Infant. 
were unusually fragile, and the entire infant skeleton was removed as a block for later laboratory cleaning. Because of the relationship of the infant skeleton to that of the adult and the unusual deterioration of portions of the adult pelvic area, field estimates suggested that the adult was a female who had died in, or shortly after, childbirth.

During final removal of the surrounding grave fill, a small clump of earth containing many small black seeds was noted in apparent association with the adult burial. Janet Stock, a researcher at Texas A\&M University specializing in paleo-floral identification, suggests that these numerous seeds are of the Compositae family. Compositae is a diverse and widespread category which, in the past, has been defined by botanists as a "difficult" group because of the complexity of its members and inadequate study. Compositae includes daisies, asters, sunflowers, tarweeds, and less common weeds.

The smal1 matrix sample containing the seeds suggests two circumstances:

(1) the seeds are the result of a disturbance, such as a rodent burrow, and are not associated with the burial; or (2) the seeds are associated with the interment and may have been a burial offering. The latter postulation is of interest since it implies a death during the seed season of this flora, presumably late summer or early fall.

A summary of data relevant to Burial 1 is presented below:

1. Burial 1 was located $70-80 \mathrm{~cm}$ below the surface, in a semiflexed position, oriented east to west (facing north), on the upper terrace of the Rio Grande.

2. No chronologically diagnostic material occurred with the interment.

3. The unusual deterioration of portions of the pelvic area in the adult female (as compared to an otherwise exceptionally well-preserved skeleton) and the presence of an infant suggest that the adult female may have died during or shortly after childbirth.

4. The presence of a small clump of Compositae seeds with Burial 1 may be an indication of seasonality (late summer-fall), although only a very general and tentative one.

5. The stratigraphic depth of Burial 1, which overlies and intrudes into several lower cultural zones of charcoal and mussel shel1 fragments, suggests the burial may be of a more recent, possibly Late Prehistoric association.

6. The lack of coastal grave goods and the appearance of river mussel shell ornaments imply that this burial was associated with an inland group of prehistoric hunters and gatherers.

\section{Burial 2}

Following the discovery of Burial 1, the site area was reassessed as to the possibility of multiple burials within the locality. The large number of subsurface examinations in the form of backhoe trenches indicated that if more burials were nearby, they would be located away from the proposed plant site. One area that had not been previously examined was a deep arroyo ca. $70 \mathrm{~m}$ south of the plant boundaries. It was suspected that if additional burials occurred they would most likely be exposed along the arroyo walls. 
Subsequent examinations discovered a second burial within the arroyo at a depth of $129 \mathrm{~cm}$ below the surface. Erosion and weathering had deteriorated and partially destroyed much of the skeleton, including portions of the skull, left hand, legs, and right arm (Fig. 20). After careful excavation, including sifting of eroded materials on the floor of the arroyo, the skeleton of a male was found to be tightly flexed, lying on its back, and oriented east to west, facing south. No burial goods were associated with the interment. No pit was identified with the burial, although several large charcoal fragments and burned sandstone rocks were uncovered beneath and around the burial. . The interment appears to have been placed over the remains of a small fire that may have preceded or perhaps been associated with the burial.

A careful examination of the arroyo walls surrounding Burial 2 revealed several mussel shell concentrations at varying depths. A small, triangular, cornernotched projectile point (Edgewood-like) was exposed in the arroyo wall at a depth of $115 \mathrm{~cm}$. Within $15 \mathrm{~cm}$ of the point and on the same level were several clay fired nodules and an undecorated ceramic sherd. Rabdotus, several cores, charcoal flecks, burned rock, and mussel shell fragments were also noted at various arroyo locations and depths.

Based on investigations to date, it cannot be determined whether other burials exist around Burial 1 and the partially eroded Burial 2. A primary reason for this uncertainty is that both burials were discovered beyond the margins of the future plant site, an area which originally had a much lower testing priority than the plant site itself. Without further subsurface testing along the arroyo and upper terrace margins, one can only speculate upon the possibility of other burials. The interior southwest corner of the plan area adjacent to the interment locations has been tested by a number of backhoe trenches, and field observations suggest that neither cultural materials nor prehistoric activities (as reflected by wall profiles) have occurred here.

Two significant observations were noted during the burial excavations. The presence of large charcoal fragments and several scattered burned sandstone rocks in and around Burial 2 may indicate the remains of a previous small burned rock cluster, much older in age than the burial, or may indicate that the small burned rock cluster was part of a burial ritual, al though no record of such activities is recorded in ethnohistorical accounts known to the present author.

Stratigraphic location suggests that the local topography (with a slope of less than three percent) over the 75-m interval between Burials 1 and 2 may indicate that Burial 1 is associated with a Late Prehistoric cultural group. Burial 1 appears relatively close to the surface and intrudes on several older cultural zones. Burial 2 may be an eroded Middle to Late Archaic phenomenon. The Edgewood-like point and ceramics from the arroyo walls were located at ca. $115 \mathrm{~cm}$ below the surface, and Burial 2 (at $129 \mathrm{~cm}$ ) appears to be stratigraphically older. These assumptions are speculative, since minimal artifactual material was found with the burials.

Evaluation of Skeletal Materials (Anthony M. Coelho, Jr., Ph.D.)

Following the cleaning, cataloging, and preliminary analys is of skeletal materials, Dr. Anthony M. Coelho, Jr., (physical anthropologist for the 


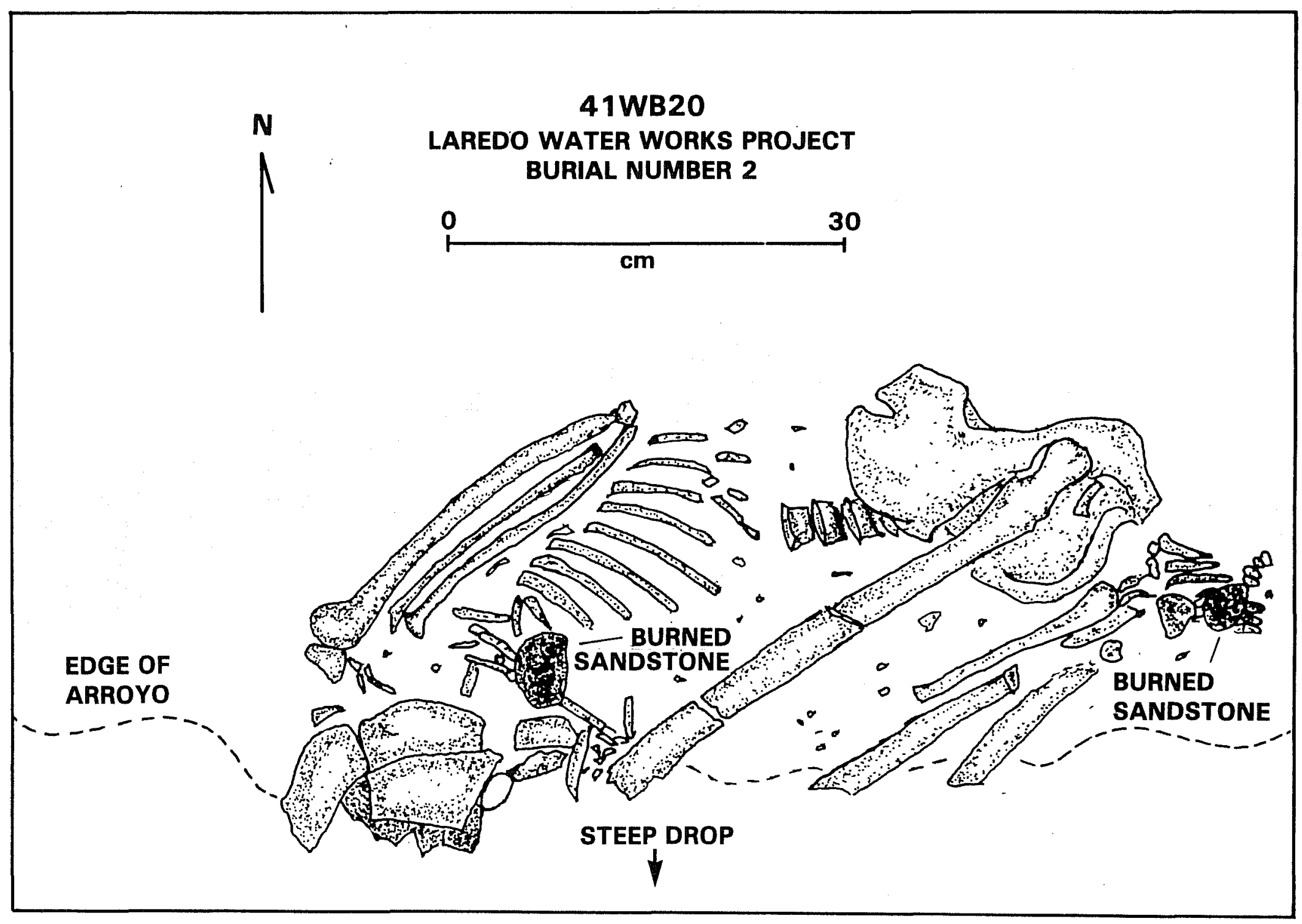

Figure 20. 41 WB 20: Burial 2.

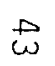


Southwest Foundation for Research and Education, San Antonio), was consulted for an expert review of the materials. Dr. Coelho's comments, which follow, are both succinct and informative.

Burial 1 consists of the partial skeleton of an adult female. A11 centers of ossification were closed, and there were no sites of epiphyseal union indicating recent fusion. There are minimal amounts of arthritic distortion present, but the bones are still relatively robust and do not suggest the development of extensive osteoporosis. I suggest that the individual was about 30 years of age at the time of her death. The innominate of the individual has some minor scarring in the pre-auricular groove in the posteromedial portion of the bone indicating that she was multiparous. Thus if the infant who was found in the same burial was her offspring then it was not her first offspring. There were no gross pathologies visible on the portions of the pelvis that were examined. The lack of the pubis precluded a more definitive estimate of age and parity of the individual. The partial cranium also exhibits no gross pathologies, but it does exhibit closure of the sutures and a general robusticity indicative of a young adult. The dentition appears complete on the left side. The right mandible and maxilla are still enclosed in the original dirt matrix and were not examined. Dental wear is apparent on all of the teeth. Molar 3 has the least amount of wear. Molar 1 and molar 2 and the canines seem to have the most wear, with the premolars and incisors also exhibiting wear. Stature estimates indicate that the individual was between 155 and $161 \mathrm{~cm}$ tall. The infant found in Burial 1 was a fragmented skeleton. The infant was less than six months old at the time of death. It is possible that the infant was a newborn who was relatively large. This would not be uncommon in a multiparous mother. It is, however, also possible that the infant was several months old at the time of death. Age estimates on the basis of long bones indicate that this infant was on the upper end of the newborn to six month old range of age and limb size. No pathologies appear in the infant's skeleton.

Burial 2 consisted of a partial skeleton of an older adult male. A11 centers of ossification are closed, and there are no epiphyseal union sites indicating recent fusion. The skeleton exhibits a reduction of muscular activity and onset of osteoporosis. The skeletal material lacks the general robusticity of bone material found in the smaller but younger Burial 1. I estimate the individual male in Burial 2 to be more than 45 years of age. No gross pathologies were present in the skeletal materials examined. The male had lost several of his teeth prior to his death. A11 three of the left mandibular molar teeth were removed, and the mandible had healed. The male had also lost teeth from the right and left maxilla. However, these losses had not healed for as long a period as the lower teeth. Although the male is much older than the female, his teeth do not give the impression of proportionally greater wear. Stature estimates indicate that the male was between 165 and $169 \mathrm{~cm}$ tall. 


\section{Corridor Area}

Following the discovery of prehistoric burials and the likelihood of extensive buried deposits directly adjacent to the proposed plant site area, the future location of an outlet corridor from the plant site to the Rio Grande took on special importance. It became critical that the eventual location of this outlet corridor not adversely affect any as yet undiscovered buried components near 41 WB 20. This corridor area was previously identified to the project archaeologists by Howard Gaddis, consulting engineer. He suggested that the maximum extent of this corridor would run from the northwest corner of the property boundary along the western limits of the site to a point ca. 300 feet south.

Ten $2 \times 6 \times 3 \mathrm{~m}$ (width, length, and depth) backhoe trenches were systematically excavated in this corridor to determine if significant cultural materials were buried in the path of future modifications. Mechanical excavations revealed loose, homogeneous, silty sands in excess of three meters in depth. Only very light scatters of charcoal flecks were noted in trenches along the upper terrace; in other areas, cultural deposits were nonexistent. Deposits in trenches along the upper terrace are light and scattered and are assumed to represent the margins of a buried cultural activity zone much more extensive in the southern portions of the plant site area and adjacent localities.

Based on comparison with previously excavated trenches, field records, and laboratory analyses, no further testing is recommended within the defined corridor area.

No further work is recommended at 41 WB 20. While cultural deposits may remain buried beneath the surface, present plans for construction will not disturb any known cultural components. The only area of mitigation beyond the plant site boundaries, the outlet corridor, has been sufficiently tested to discount the possibility of other buried components.

41 WB 21

Location: In the eastern margins of the proposed plant site area (Fig. 11).

Dimensions: The very light scatter of lithic materials and negligible subsurface deposits make the site boundaries difficult to determine. Tentative estimate of site dimensions is $\mathrm{ca} .150 \times 100 \mathrm{~m}$.

Type of Site: Light activity, Tithic workshop site.

Distance from Nearest Water Source: ca. 400-500 m west.

Elevation: 400 feet ms 1 .

Site Condition: Surface of the site has been cleared; possibly root plowed.

Investigations: Following the discovery of several chert flakes and other scattered lithic debris, the area was intensively surveyed and tested by trenching. No surface features or subsurface deposits were noted. The site is believed to consist of a very light surface scatter of artifacts and may exist as the 
very fringe of a larger site farther south and east of the study area or as a casual workshop area of a quarry site containing Uvalde Gravels. Since no diagnostic artifacts were found and very few cultural materials noted, no further work is recommended at this locality.

\section{CULTURAL MATERIÁLS}

Intensive survey and subsurface testing recovered a number of both prehistorical and historical artifacts, and these will be briefly described below. Subsections will include specific material types. The description of cultural materials presents only the results of a preliminary analysis, and it must be recognized that certain artifact categories, particularly those of lithic tool types, are tentative and may be further redefined. Provenience of many of the artifacts is from surface collections, and associations with various cultural components are tenuous.

Because of the present-day approach to south Texas archaeology and the lack of extensive cultural studies, an arbitrary descriptive classification system of materials has certain advantages over a functional typological system: (1) it is less time-consuming than the more tedious wear and/or utilization studies inherent in functional classification; (2) it contains a reproducible format for later comparative studies; (3) it contains elements which can be easily interpreted by a wide variety of readers and researchers; and (4) it can be argued that objective and detailed artifact descriptions and groupings are a prerequisite to more complex functional studies. Unfortunately, descriptive systems also contain several shortcomings: (1) they do little to actually define the artifact in its original cultural context; (2) the descriptive classification system is completely arbitrary and dependent upon the judgment and knowledge of the researcher; and (3) the classification scheme does not ordinarily account for spatial, temporal, and various cultural distinctions.

Because of time limitations, the extent of cultural materials, and contractual goals, a descriptive classification systems was considered adequate to describe the artifact collection.

\section{Projectile Points}

A wide variety of dart points, arrow points, and fragments were collected from the investigated sites. The majority of these are from surface collections (unless otherwise noted) and represent culturally distinct projectile point types. Dart point types were classified by morphology and compared with Suhm and Jelks (1962). Morphological groups and forms are defined in Table 2. The descriptions of the artifacts are separated into individual site collections. A summary of point types, frequencies, and collection areas is presented in Table 3 .

Abbreviations used for artifact measurements are $L$ : length; W: width; $T$ : thickness; and WT: weight. Length, width, and thickness are measured in centimeters; weight is measured in grams. 
TABLE 2. PROJECTILE POINT MORPHOLOGY

GROUP 1. Triangular Blade, Non-Stemmed FORM 1. Rounded edges, convex base FORM 2. Diminutive, convex base FORM 3. Narrow blade, convex base FORM 4. Equilateral

FORM 5. Narrow blade, straight base

GROUP 2. Contracting Stem, Triangular BTade FORM 1. Large FORM 2. Diminutive

GROUP 3. Expanding Stem, Triangular Blade FORM 1. Straight base, squared shoulders FORM 2. Straight base, angled shoulders FORM 3. Straight base, unsymmetrical lateral blade edges

GROUP 4. Expanding Stem, Lanceolate Blade 
TABLE 3. PROVENIENCE OF COMPLETE PROJECTILE POINTS

\begin{tabular}{|c|c|c|c|c|c|}
\hline \multirow[b]{2}{*}{$\begin{array}{l}\text { Complete } \\
\text { Projectile Points }\end{array}$} & \multicolumn{5}{|c|}{ Site } \\
\hline & 41 WB 13 & $\begin{array}{l}41 \text { WB } 15 \\
\text { (south) }\end{array}$ & $\begin{array}{l}41 \text { WB } 15 \\
\text { (north) }\end{array}$ & 41 WB 17 & 47. WB 20 \\
\hline \multicolumn{6}{|l|}{ Group 1} \\
\hline Form 1 (Abasolo) & 1 & 2 & & & \\
\hline Form 2 (Catán) & 1 & 1 & & 1 & \\
\hline Form 4 (Tortugas/ & & & & & \\
\hline Early Triangular) & 2 & 2 & 1 & 1 & \\
\hline $\begin{array}{l}\text { Form } 5 \\
\text { Form } 6\end{array}$ & 1 & & 1 & & \\
\hline
\end{tabular}

Group 2

Form 1

Form 2 (Perdiz)

$\begin{array}{ll}1 & 1\end{array}$

Group 3

Form 1 (Rio Bravo)

Form 2 (Edgewood)

Form 3 (Shumla)

Group 4

Note: A1l specimens are from surface collections, unless otherwise noted.

Group 1. Triangular B1ade, Non-Stemmed--Group 1 is characterized by a generally triangular outline, with the exception of the variant Form 6 . Blade edges vary from broad, rounded edges with a convex base to more narrow, straight-based artifacts. Basal thinning is often identifiable in the form of small percussion flakes removed perpendicular to the basal plane. Pronounced edge beveling is noted on some specimens and may reflect later resharpening or reshaping. Form 6 , a bipointed artifact, is included in this group as a variation of the triangular shape. It may also be appropriately placed in its own unique group after a much wider sample is reviewed.

Group 2. Contracting Stem, Triangular Blade--Form 1 is an unidentified projectile point type, although the lack of extensive pressure flaking may be indicative of a preform stage of the smaller Perdiz (Form 2) arrow point.

Group 3. Expanding Stem, Triangular Blade--Variations within this group of triangular-bladed, expanding-stemmed, straight-based dart points are characterized by the type and symmetry of the corner-notched blades. Form 1, represented 
by only one artifact, is not depicted by Suhm and Jelks (1962) and may represent a minor cultural association from locations south of the Rio Grande.

Group 4. Expanding Stem, Lanceolate Blade--Only one specimen was found in this category. Refer to page 54 for the descriptive characteristics of this projectile point.

41 WB 13 (four complete specimens; one basal fragment)

A11 points were collected from uncontrolled surface collections unless otherwise noted.

Group 1, Form 1 (one basal fragment; Fig. 21,a)

The base is thinned and very slightly convex with rounded edges. Large percussion flake scars across the artifact suggest that this may be a preform fragment of an Abasolo or Catan-like projectile point. L: $3.75 ; \mathrm{W}: 3.37 ; \mathrm{T}: 0.70$; WT: 10.8 .

Group 1, Form 3 (one specimen; Fig. 21, b)

The blade on this artifact is triangular, and the edges are slightly alternately beveled. The base is convex, and the edges are well rounded. The stem is also noticeably thinned. It is similar in form to Suhm and Jelks' (1962) description of Refugio points. L: $5.1 ; W: 2.2 ; \mathrm{T}: 0.76 ; W T: 8.8$.

Group 1, Form 4 (two specimens; Fig. $21, \mathrm{c}-\mathrm{d}$ )

Specimen 1 (Fig. 21,C) has a steep, alternately beveled blade with serrated edges. The base is thinned, and the distal tip is slightly asymmetric, possibly due to resharpening. Specimen 2 (Fig. 21,d) is also alternately beveled, like Specimen 1, on the left blade face. The provenience of Specimen 2 is Test Unit 2, Leve1 1 $(0-30 \mathrm{~cm})$. Specimen 1: L: $5.3 ; \mathrm{W}: 2.7 ; \mathrm{T}: 0.65 ; \mathrm{WT}: 6.9$. Specimen 2: L: $4.9 ; W: 2.8 ; T: 0.76 ; W T: 10.4$.

Group 1, Form 6 (one specimen; Fig. 21,e)

This artifact differs from Group 1, Form 3 by the angularity of the stem. One blade face is noticeably beveled along both edges, and the stem is thinned. The specimen is similar to Suhm and Jelks' (1962) description of the Desmuke type, although this specimen has almost parallel rather than triangular blade edges. L: $5.1 ; W: 2.0 ; T: 0.87 ; W T: 9.0$. 


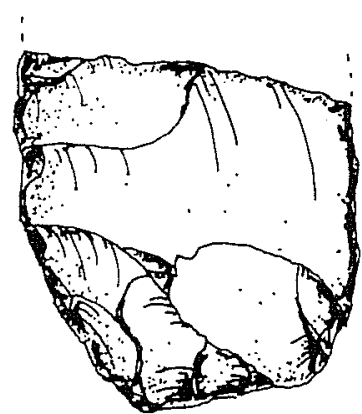

a

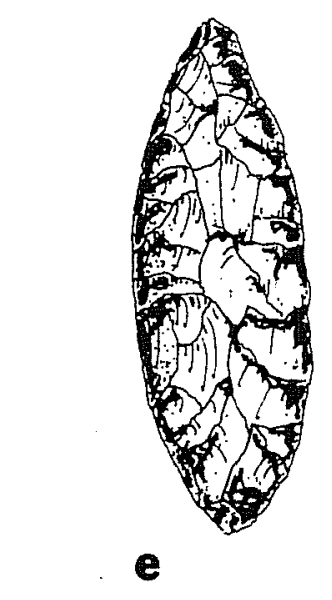

e

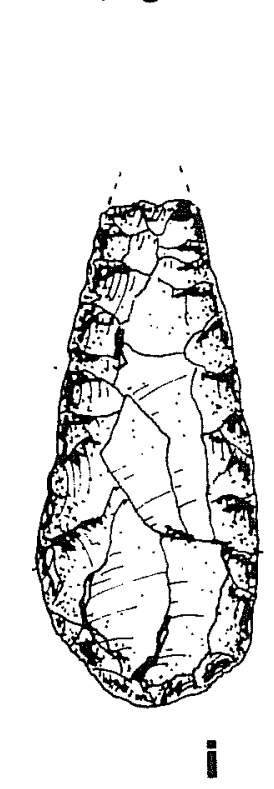

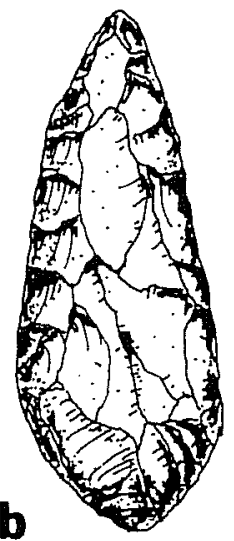

b

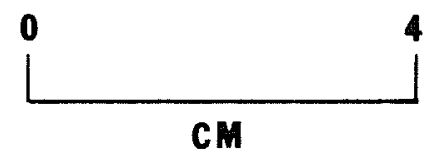

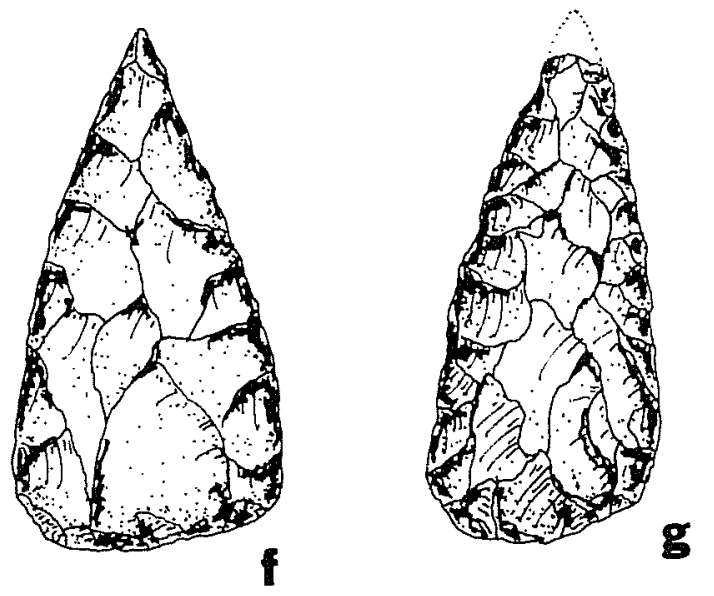

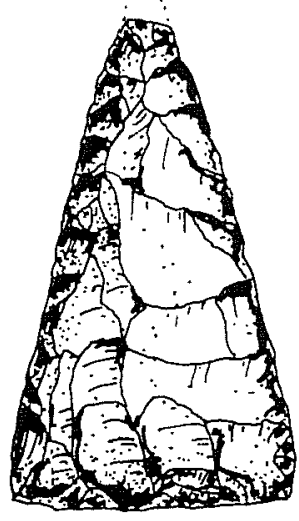

C

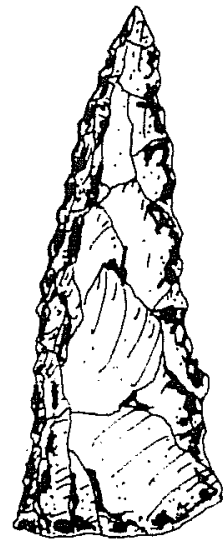

d
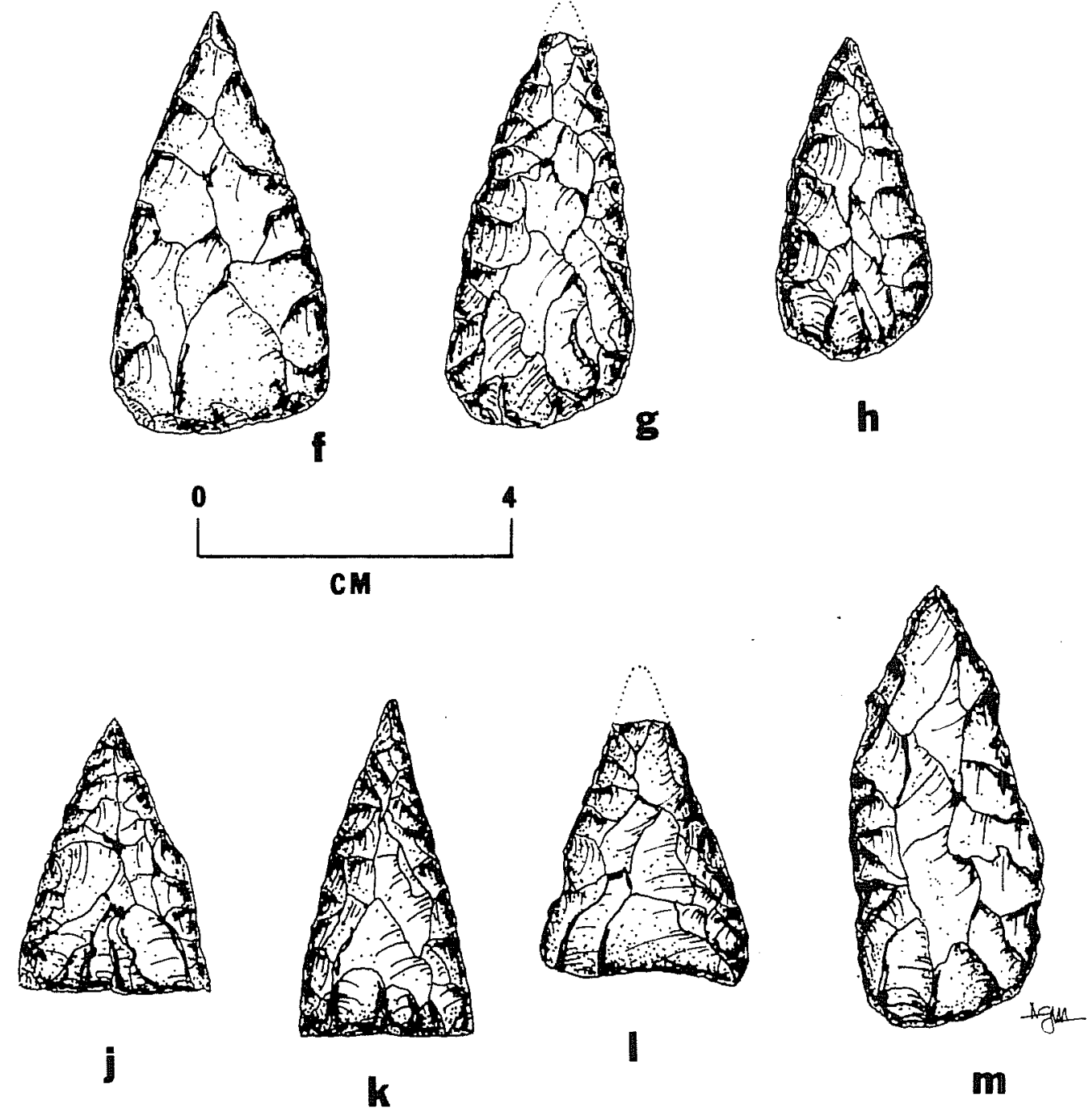

Figure 21. Projectile Points. a, Group 1, Form 1, 41 WB 13; b, Group 1, Form 3, 41 WB 13; c-d, Group 1, Form 4, 41 WB 13; e, Group 1, Form 6, 41 WB 13; f-g, Group 1, Form 1, 41 WB 15; h, Group 1, Form 2, 41 WB 15; i, Group 1, Form 3, 41 WB 15; j-1, Group 1, Form 4, 41 WB 15; m, Group 1, Form 5, 41 WB 15. 
41 WB 15 (14 complete specimens; six basal fragments)

Al1 descriptions are from uncontrolled surface collections, southern site locus, unless otherwise noted.

Group 1, Form 1 (two complete specimens; Fig. 21,f-g)

Both artifacts are subtriangular with slight to moderately rounded basal edges and convex bases. Both specimens display basal thinning. Specimen 1 (Fig. 21,f) reflects edge beveling on one face. Both of these projectile points are similar to the Abasolo type as defined by Suhm and Jelks (1962). Specimen 1: L: 5.4; W: 2.9; T: 0.66; WT: 8.7. Specimen $2(F i g .21, g):$ L: $5.0 ; W: 2.4 ; T: 0.72$; WT: 9.1 .

Group 1, Form 2 (one complete specimen; Fig. 21,h)

The sma11, leaf-shaped point has rounded proximal edges and a convex base. The blade is steeply beveled on both faces. It is similar in outline to Group 1, Form 1 except smaller and lighter. This artifact is similar to the Catan type as described by Suhm and Jelks (1962). L: 4.0; W: 2.0; T: 0.79; WT: 6.2.

Group 1, Farm 3 (one complete specimen; Fig. 21,i)

The base of this specimen is almost semicircular. The blade is thick, but the proximal portion of the artifact is thinned. The narrow blade distinguishes this artifact from Group 1, Form 1. The specimen is similar to the Refugio type as described by Suhm and Jelks (1962). The provenience of this specimen is Test Unit 1, Level 2 $(10-20 \mathrm{~cm})$. L: $5.0 ; W: 2.3 ; \mathrm{T}: 0.85 ; \mathrm{WT}: 10.2$.

Group 1, Form 4 (three complete specimens; Fig. $21, j-1$ )

A11 specimens except Specimen 3 are alternately beveled along the left blade edges on both faces. All bases are thinned by multiple flaking, and the distal ends are worked to finely flaked points. The artifacts are similar to the Tortugas type as defined by Suhm and Jelks (1962). Specimen 1 (Fig. 21,j): L: 3.4; W: 2.4; T: 0.72; WT: 5.1. Specimen 2 (Fig. 21, K): L: 4.3; W: 2.3; $\mathrm{T}: 0.68 ; W T: 5.9$. Specimen $3($ Fig. 21,1$): \mathrm{L}: 3.8 ; \mathrm{W}: 3.1 ; \mathrm{T}: 0.63$; WT: 5.4 .

Group 1, Form 5 (one complete specimen; Fig. $21, \mathrm{~m}$ )

This specimen is from a surface collection, northern site locus. It has a narrow, triangular blade and no stem. Blade edges are convergent and alternately beveled. The base is thinned, and the point is crudely worked. The artifact is quite thick along the blade median. This may actually be a preform, although moderate nicking and step fracturing along the blade edges indicate possible multifunctional usage. L: $5.3 ; \mathrm{W}: 2.5 ; \mathrm{T}: 1.1 ; \mathrm{WT}: 15.4$. 
Group 2, Form 1 (one complete specimen; Fig. 22,a)

The blade and stem of this point are alternately beveled, and the artifact is finely pressure flaked. The base is straight, and the shoulders are squared. L: $4.4 ; W: 2.3 ; T: 0.57$; WT: 5.9 .

Group 2, Form 2 (two complete specimens; Fig. 22,b,c)

The blades on these specimens are triangular with slightly convex edges. Shoul-. ders are perpendicular to stems. Specimen 1, although similar to a large Perdiz point, appears to be a possible preform. Specimen 1 (Fig. 22,b): L: 3.7; W: 2.4; T: 0.73; WT: 6.5. Specimen 2 (Fig. 22,c): L: 2.7;W: 1.5; T: 0.28 ; WT: 1.0 .

Group 3, Form 1 (one complete specimen; Fig. 22,d)

This projectile point has an expanding stem with a finely worked triangular blade. The specimen has an uncurved base and appears to be manufactured from quartzite. Shoulders are broad and distinctly squared at the ends, and shoulder edges do not quite continue to the level of the base. A slight convex curve is formed by the squared shoulders and the stem base. Stem length is $4.0 \mathrm{~cm}$, basal width is $1.6 \mathrm{~cm}$, and neck thickness is ca. $0.27 \mathrm{~cm}$. The squared shoulders uniquely define the point type in Texas, although cultural associations are poor. The apparent limited frequency and lack of previous descriptions suggest only restricted distributions of this particular cultural style in southern Texas. A similar type (Slentz Barbed) has been briefly defined by Michael Spence (1971: 45) from locations at the Llano Grande-El Salto region of the Sierra Madre 0ccidental in central Durango, Mexico. This is also similar to an unclassifiable point type mentioned by Campbell and El1 is (1952:Fig. 72, bottom left) and by Martin et al. (1952:Fig. $45, f-g)$, which may be related to San Pedro and Mogollon cultures in the middle Rio Grande Valley. Spence (1971:45) suggests, very tentatively, that his point type reflects one of a series of San Pedrorelated preceramic cultures which developed into Mogolion in the United States and into the Mogollon-related Loma San Gabriel culture in southern Chihuahua and Durango. While styles appear similar, actual cultural, temporal, and spatial relationships are tentative, and at this point are not definable. The artifact may represent the Texas variant of the square-shouldered point which may or may not be related to Spence's (1971) Slentz Barbed and the unclassified type noted by Campbel1 and Ellis (1952). L: 4.0;W: 2.9; T: 0.47; WT: 4.4 .

Group 3, Form 3 (one complete specimen; Fig. 22,e)

This artifact is characterized by its triangular blade, slightly expanding stem, and asymmetric blade edges. The specimen is deeply corner notched and appears to be heat treated. The blade is short in contrast to the thick, wide stem. This may represent a shortened, reworked blade. The artifact is similar to Shumla as described by Suhm and Jelks (1962) and by Hester and Collins (1974). L: $4.4 ; W: 3.4 ; \mathrm{T}: 0.8 ; \mathrm{WT}: 10.2$. 

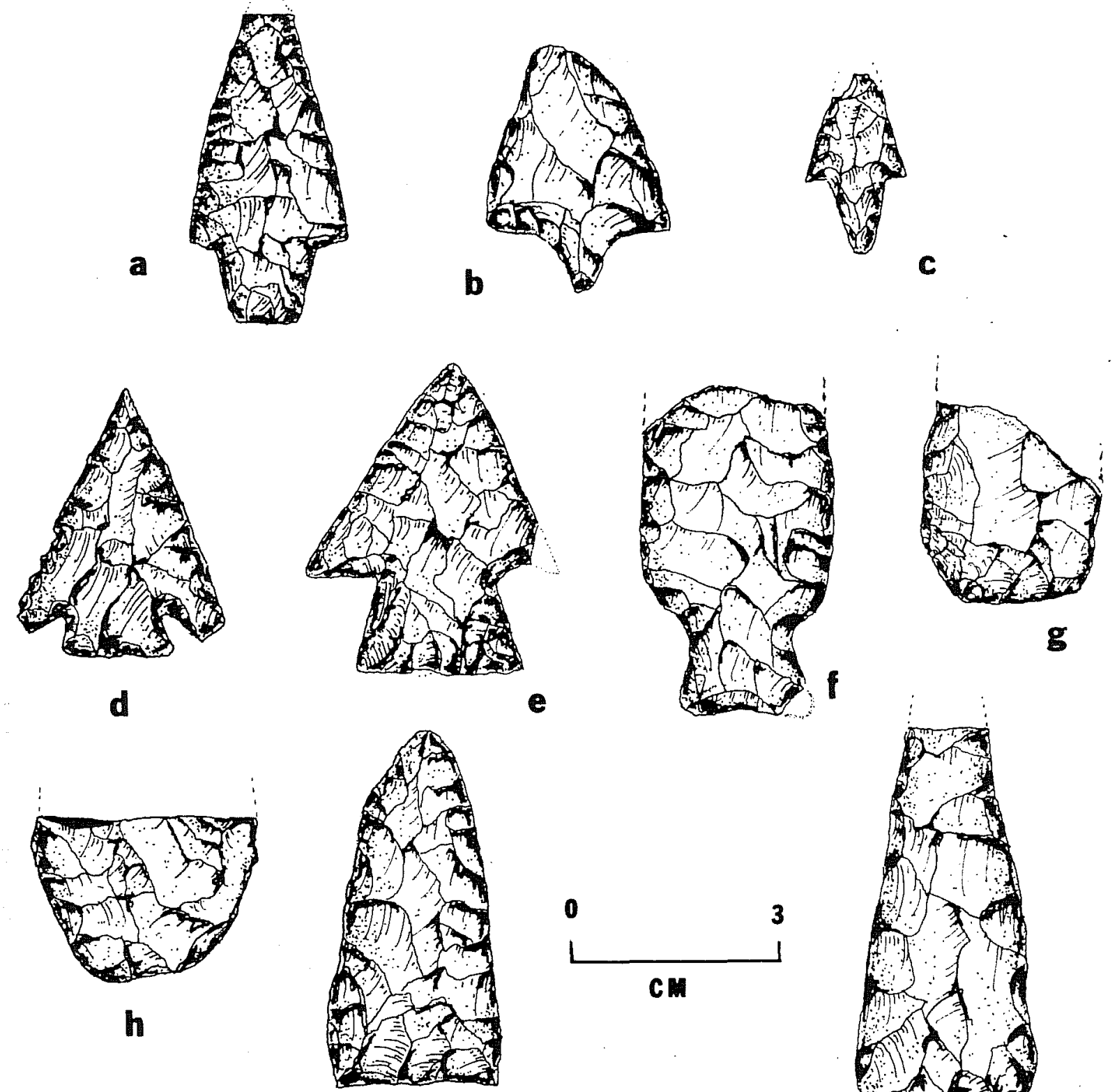

C
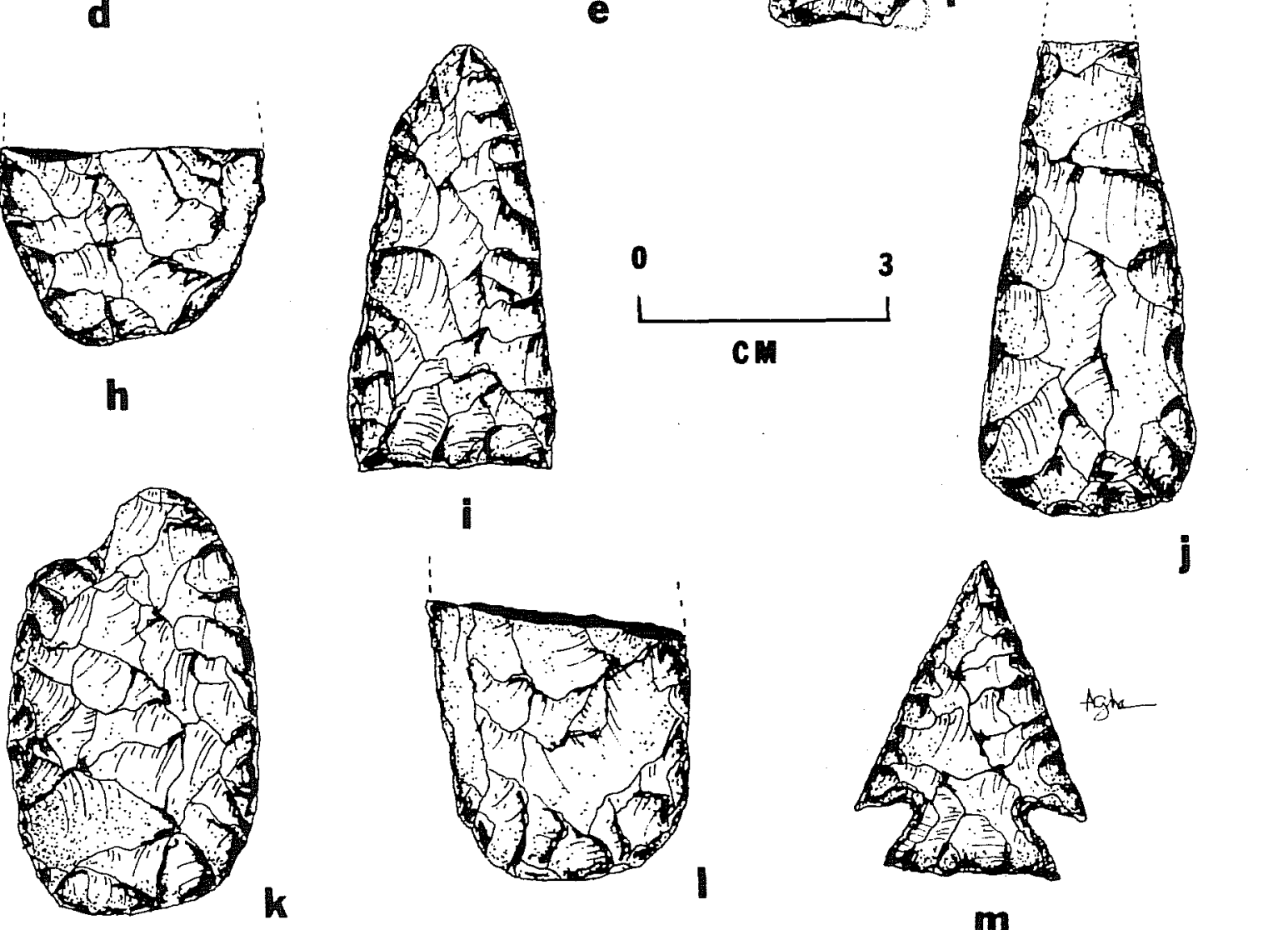

k
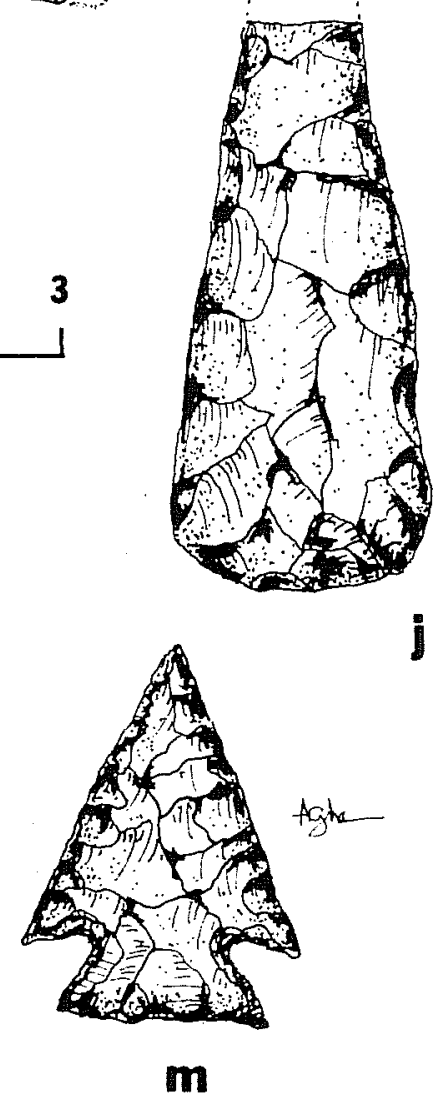

Figure 22. Projectile Points. a, Group 2, Form 1, 41 WB 15; b-c, Group 2, Form 2, 41 WB 15; d, Group 3, Form 1, 41 WB 15; e, Group 3, Form 3, 41 WB 15; f, Group 4, 41 WB 15; g-h, Group 1, Form 1, 41 WB 16; i, Group 1, Form 4, 41 WB 17; j, Group 1, Form 3, 41 WB 17; k-1, Group 1, Form 1, 41 WB 17; m, Group 3, Form 3, 41 WB 20. 
Group 4 (one complete specimen; Fig. 22,f)

This specimen is patinated and finely worked. The stem is thinned, slightly beveled, and slightly convex. Shoulders are barbless and rounded. The tip is missing so the estimated length varies from 5.5 to $6.5 \mathrm{~cm}$. Stem length is 1.2 , basal width is 7.9 , and basal thickness is 0.69 . The point is similar to the tentative Zorra type defined in Johnson's (1964:45) report on the Devil's Mouth site in Val Verde County. Zorra points are associated with Early and Middle Archaic contexts in that area.

Basal Fragments (six specimens; uncontrolled surface collections; Fig. 23,a-f)

Specimen 1 (Fig. 23;a) is a finely worked basal fragment of a dart point with rounded basal edges and thinned base. An extension of the blade edges presumably would result in a smal1, lanceolate artifact. L: $2.6 ; \mathrm{W}: 2.1 ; \mathrm{T}: 0.67$; WT: 5.1 .

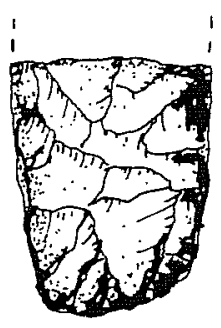

a

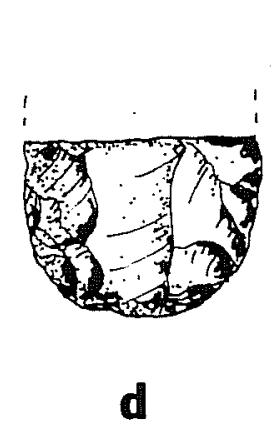

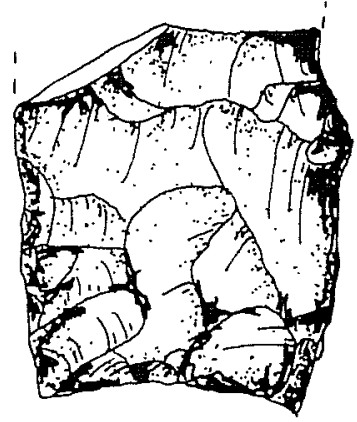

b

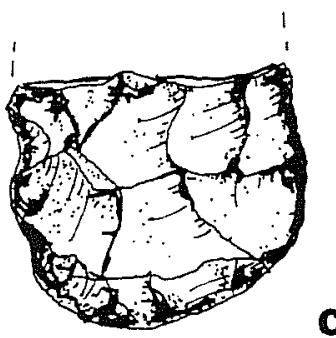

C

3

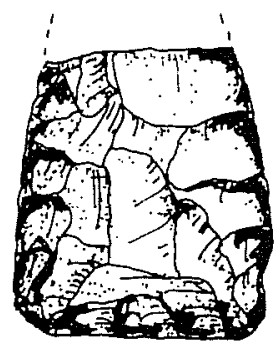

Cm

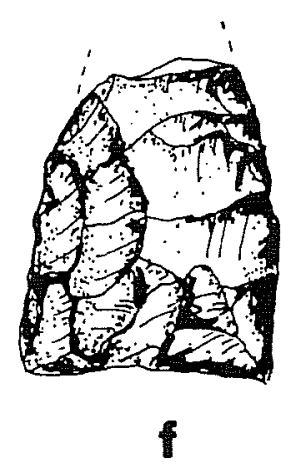

Figure 23. 41 WB 15: Proximal Projectile Point Fragments. 
Specimen 2 (Fig. $23, \mathrm{~b}$ ) appears to belong to a parallel-sided biface. L: 3.9; W: $3.3 ; \mathrm{T}: 0.65 ; \mathrm{WT}: 11.5$.

Specimens 3 (Fig. 23,C) and 4 (Fig. 23,d) are similar to Group 1, Form 1 (Abasolo or Refugio as described by Suhm and Jelks [1962]). Specimen 3: L: $3.1 ; \mathrm{W}: 3.0 ; \mathrm{T}: 0.59$; WT: 6.0. Specimen 4: L: 1.8; W: 2.9; T: 0.62 ; WT: 3.7 .

Specimens 5 (Fig. 23,e) and 6 (Fig. 23,f) are the proximal portions of small, thin triangular dart points with straight, thinned bases. They are similar to the smal1 Tortugas type (Group 1, Form 4) or Matamoros type. Tentative associations at 41 WB 15 suggest later Archaic associations for these small triangular projectile points. Specimen 5: L: 3.0; W: 3.1; T: 0.59; WT: 6.4. Specimen 6: L: $3.2 ; W: 2.5 ; T: 0.59 ; W T: 5.6$.

41 WB 16 (two proximal fragments)

Group 1, Form 1 (Fig. 22,g-h)

Specimen 2 has a thinned base, but a flat cortex platform remnant is still 10cated on a corner of the base. Both specimens are similar to Abasolo as defined by Suhm and Jelks (1962). Specimen 1 (Fig. 22,g): L: 2.8; W: 2.6; T: 0.59; WT: 5.8. Specimen 2 (Fig. 22,h): L: 2.4;W: 3.2; T: 0.54; WT: 5.5.

41 WB 17 (two complete specimens; two basal fragments)

Group 1, Form 1 (two basal fragments; Fig. 22,k-1)

Specimen 2 has a reworked distal end; it is notched and surrounded. by nicking. Specimen 1 is a crudely worked artifact similar to the Abasolo type as defined by Suhm and Jelks (1962). Specimen 1 (Fig. 22, K): L: 3.51; W: 3.1; T: 7.5; WT: 9.4. Specimen 2 (Fig. 22,1): L: $5.6 ; \mathrm{W}: 3.3 ; \mathrm{T}: 7.8 ; \mathrm{WT}: 14.1$.

Group 1, Form 3 (one complete specimen; Fig. 22,j)

This specimen is a narrow-bladed, convex, stemmed point with rounded shoulders. The stem is thinned. The artifact is similar to Refugio or Abasolo types as described by Suhm and Jelks (1962). The specimen was recovered from Test Unit 2, Leve $17(0-30 \mathrm{~cm})$. L: $5.8 ; \mathrm{W}: 2.8 ; \mathrm{T}: 0.92 ; \mathrm{WT}: 13.8$.

Group 1, Form 4 (one complete specimen; Fig. 22,i)

This specimen is a crudely manufactured, preformlike object with one beveled edge, a thinned base, and a comparatively thick blade. The stem is thinned. The artifact was surface collected. L: $5.0 ; \mathrm{W}: 2.7 ; \mathrm{T}: 0.8$; WT: 10.5 . 
Group 3, Form 3 (one complete specimen; Fig. $22, \mathrm{~m}$ )

One specimen was recovered from an arroyo wall at the southern end of the site at a depth of $\mathrm{ca} .115 \mathrm{~cm}$. The blade is triangular and corner notched, with an expanding stem and straight base. Blade edges are moderately beveled on both faces, and the shoulders are barbed. The specimen is similar to the Edgewood type as described by Suhm and Jelks (1962). L: 3.8; W: 2.9; T: 0.6; WT: 5.5 .

\section{Bifaces and Unifaces}

Bifaces, unifaces, and fragments were grouped by morphology. Categories were based on shape and described as irregular, subrectangular, subdiscoidal, ovate, triangular, and sublanceolate. The "sub-" prefix is equivalent to "-like" in identifying the closest shape category. These general groups were often divided into subgroups, or forms, based upon particular variations within the general group range of characteristics.

To partially offset the lack of functional attribute information, the artifacts were later regrouped according to macroscopically observable degrees of working edge angles as determined by an SK goniometer. Artifacts were resorted not by shape but by the function of identifiable working edge angles. Working edge angles of stone tools are usually easily recognizable and are considered major determinants of tool usage. These groups are illustrated in Figure 24 , which shows not only the frequencies of edge angle groups but also the relationship between morphological classes.

A1.1 artifacts were made of fine-grained, siliceous stone (chert), medium to dark brown in color, unless otherwise noted. These materials are common in the study area in the form of river cobbles or from nearby deposits of upland gravel sources.

Morphological groups and forms are described in Table 4.

Group 1. Subrectangular (12 specimens)

These artifacts have four sides with rounded edges at approximate right angles. Edges and ends are parallel, and the artifacts are plano-convex.

Form 1 (seven specimens; Fig. 25,a-c, Specimens 2, 3, and 4, respectively)

All specimens have a high length-width ratio. Most exhibit moderate to steep retouch along edges. Specimens 5 and 7 may be identified as formal tools similar to the Nueces scraper as described by Hester, White, and White (1969). These two artifacts are plano-convex in cross section and are marginally worked bifaces. Length of these two tools ranges from $3.9-4.2 \mathrm{~cm}$, and width of working edges is 


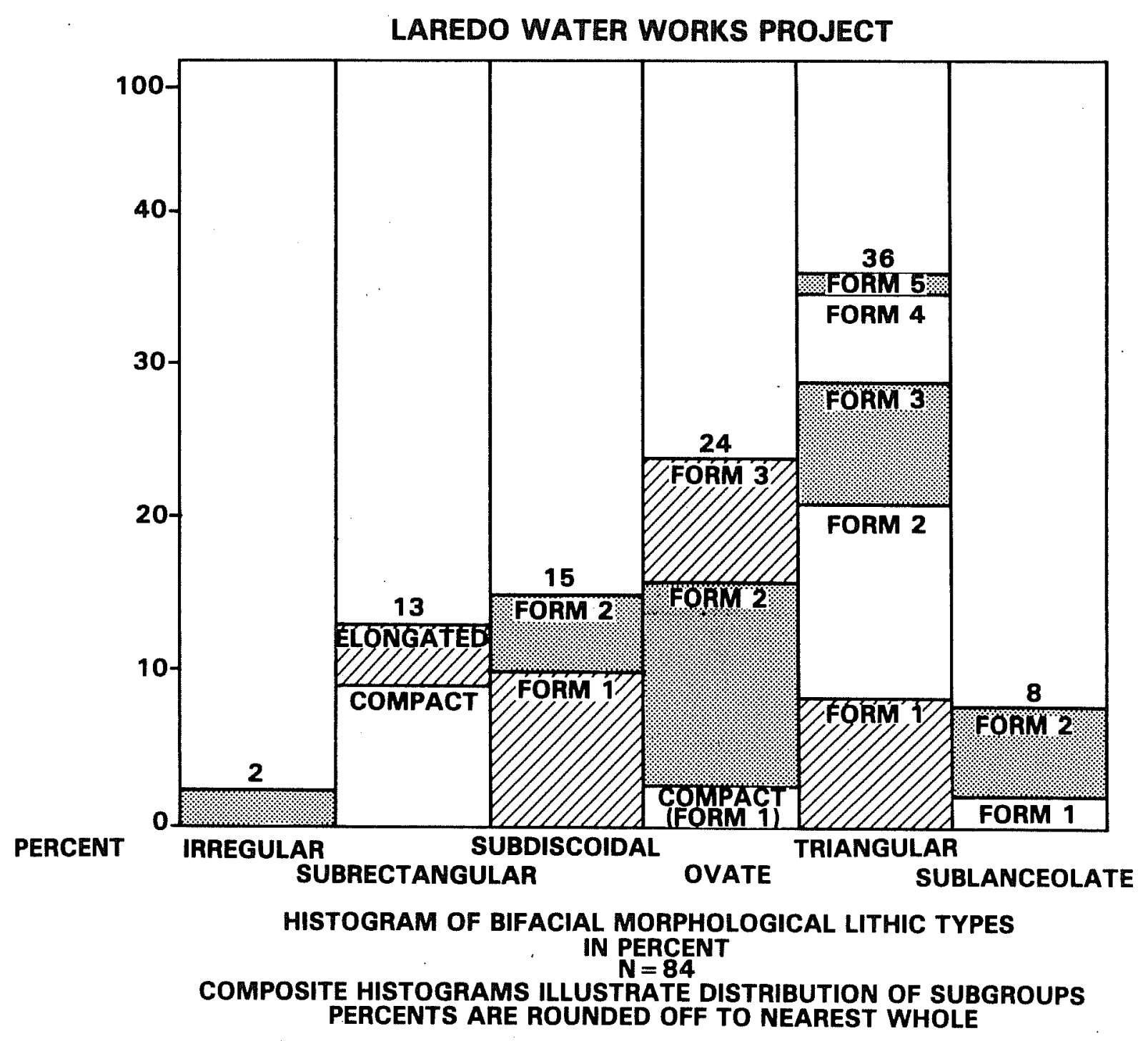

Figure 24. Composite Histograms of Morphological Biface Groups. 
TABLE 4. BIFACE MORPHOLOGICAL GROUPS

GROUP 1. Subrectangular

FORM 1. Subrectangular, compact

FORM 2. Elongated

GROUP 2. Subdiscoidal

FORM 1. Circular

FORM 2. Transitional (to Ovate)

GROUP 3. Ovate; Elliptical

FORM 1. Compact

FORM 2. Ovate

FORM 3. Transitional (to Triangular)

GROUP 4. Triangular

FORMS 1-4. Variations dependent on cross sections and blade widths

GROUP 5. Lanceolate

FORM 1. Wide

FORM 2. Narrow 


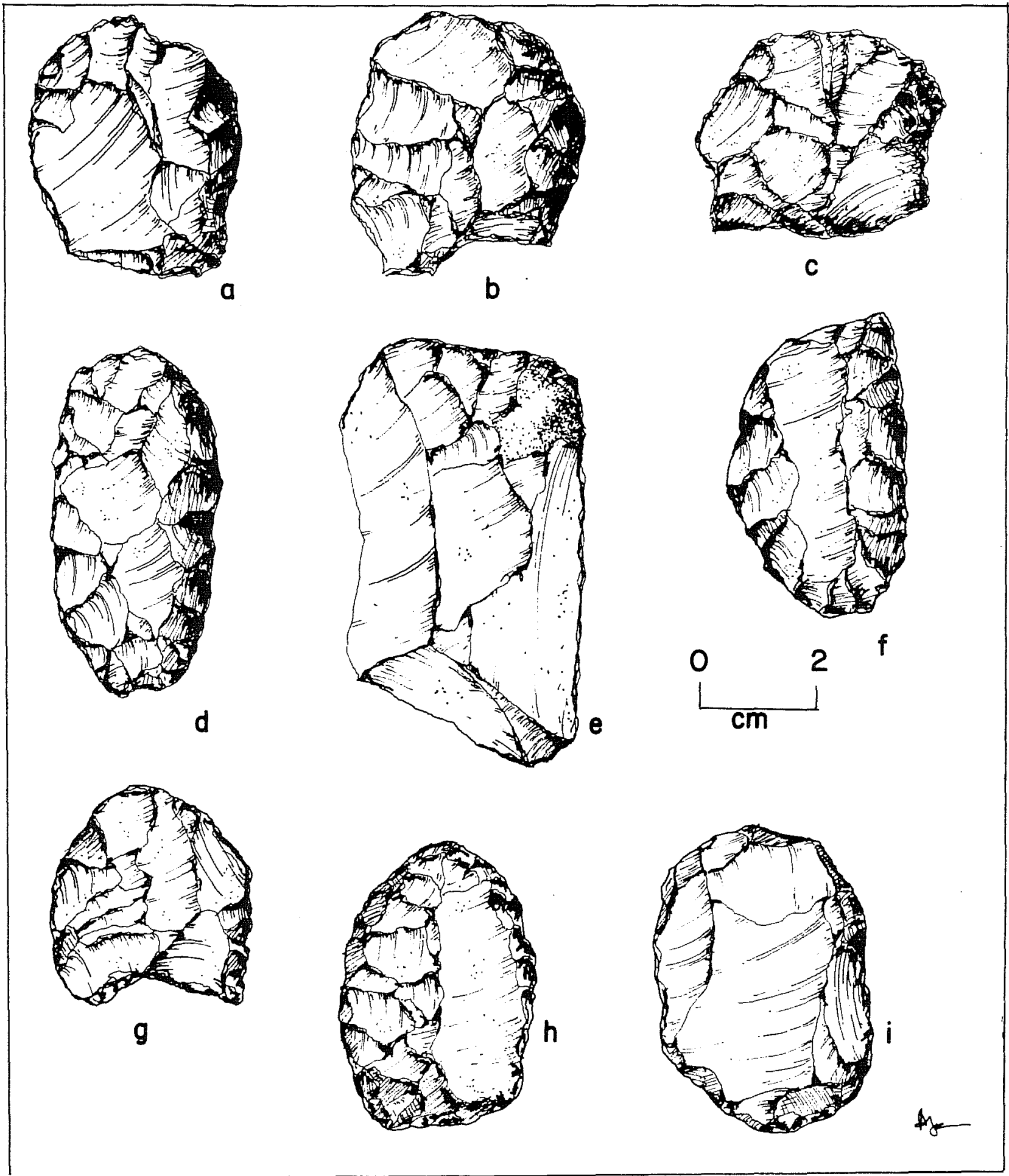

Figure 25. Biface Groups. a-c, Group 1, Form 1 (subrectangular, compact); $\mathrm{d}-\mathrm{f}$, Group 1, Form 2 (subrectangu1ar, elongated); g-i, Group 2, Form 1 (subdiscoidal, circular). 
from $3.7-3.9 \mathrm{~cm}$. Measurement range for Form 1 specimens: $L: 4.0-4.2 ; W: 2.5-$ 3.9; T: 0.8-1.9. See Table 5 for provenience data.

Form 2 (five specimens; Fig. 25,d-f, Specimens 1 and 2, respectively)

A11 specimens are subrectangular, parallel sided, lengths distinctly greater than widths, and straight ends with rounded edges. Measurement range of Form 2 specimens: $L$ : 4.9-7.1; W: 3.2-4.1; T: 1.05-2.4. See Table 6 for provenience of specimens.

Group 2. Subdiscoidal (14 specimens)

These specimens are rounded and biconvex or plano-convex in cross section.

Form 1 (nine specimens; Fig. 25,g-i, Specimens 1, 2, and 3, respectively)

These artifacts are approximately circular, varying in size and thickness. Eight specimens appear utilized. One is a preformlike artifact. Measurement range:

$L: 4.7-5.1 ; W: 2.8-3.7 ; T: 1.7-2.1$. See Table 7 for provenience data.

Form 2 (five specimens; Fig. 26,a-c)

These artifacts are more angular and appear as an intermediate group between discoidal and ovate classes. Width varies noticeably with form. Specimen 4 is the proximal fragment of a bifacially flaked perforator with an alternately beveled but broken blade. Measurement range: $L: 5.8-7.4 ; W: 3.7-4.6 ; T: 0.9-$ 1.9. See Table 8 for provenience data.

Group 3. Ovate; Elliptical (21 specimens)

Form 1 (two specimens; Fig. 26,d-e)

These specimens have a high length-width ratio. Cross section varies, although most specimens are biconvex or plano-convex. The specimen from $41 \mathrm{WB} 16$ is a marginally trimmed biface; the ventral face is only invasively retouched. Multiple step fractures, presumably hinge-type, were noted on the right dorsal proximal edge. Specimen 1 was collected from site 41 WB 16, Specimen 2 from 41 WB 15. Specimen 1 (Fig. 26,d): L: 5.5; W: 3.6; T: 1.9. Specimen 2 (Fig. 26,e): L: $5.9 ; W: 3.6 ; T: 1.8$.

Form 2 (12 specimens; Fig. $26, f-h)$

This group includes all ovate fragments. Measurement range: $L:$ 5.7-6.9; W: 3.6-4.7; T: 1.1-1.9. See Table 9 for provenience data and comments. 
TABLE 5. PROVENIENCE OF GROUP 1, FORM 1 SPECIMENS

\begin{tabular}{cll} 
Specimen No. & \multicolumn{1}{c}{ Site } & Collection \\
\hline 1 & 41 WB 13 & surface \\
2 & 41 WB 15 & Test Unit T, Leve 2 \\
$(10-20 \mathrm{~cm})$ \\
3 & 41 WB 15 & surface \\
4 & 41 WB 15 & surface \\
5 & 41 WB 15 & Test Unit 1, Leve1 1 \\
6 & 41 WB 16 & (0-10 cm) \\
7 & 41 WB 16 & surface' \\
& &
\end{tabular}

TABLE 6. PROVENIENCE OF GROUP 1, FORM 2 SPECIMENS

\begin{tabular}{cll} 
Specimen No. & Site & Collection \\
\hline 1 & 41 WB 13 & surface \\
2 & 41 WB 15 & surface, northern locus \\
3 & 41 WB 15 & surface, southern locus \\
4 & 41 WB 15 & surface, southern locus \\
5 & 41 WB 15 & surface, southern locus
\end{tabular}

\section{TABLE 7. PROVENIENCE OF GROUP 2, FORM 1 SPECIMENS}

\begin{tabular}{cll} 
Specimen No. & Site & Collection \\
\hline 1 & 41 WB 13 & surface \\
2 & 41 WB 15 & surface, northern locus \\
3 & 41 WB 15 & surface, southern locus \\
4 & 41 WB 15 & surface, northern locus \\
5 & 41 WB 15 & surface, northern locus \\
6 & 41 WB 15 & Test Unit 1, Leve 3 \\
7 & 41 WB 16 & (20-30 cm) \\
8 & 41 WB 20 & surface \\
9 & 41 WB 20 & surface \\
& & \\
\end{tabular}

TABLE 8. PROVENIENCE OF GROUP 2, FORM 2 SPECIMENS

\begin{tabular}{cll} 
Specimen No. & Site & Collection \\
\hline 1 & 41 WB 15 & surface, northern locus \\
2 & 41 WB 15 & surface, southern locus \\
3 & 41 WB 15 & surface, northern locus \\
4 & 41 WB 15 & surface, northern locus \\
5 & 41 WB 15 & Test Unit 1 , Level 3 \\
$(20-30 \mathrm{~cm})$
\end{tabular}




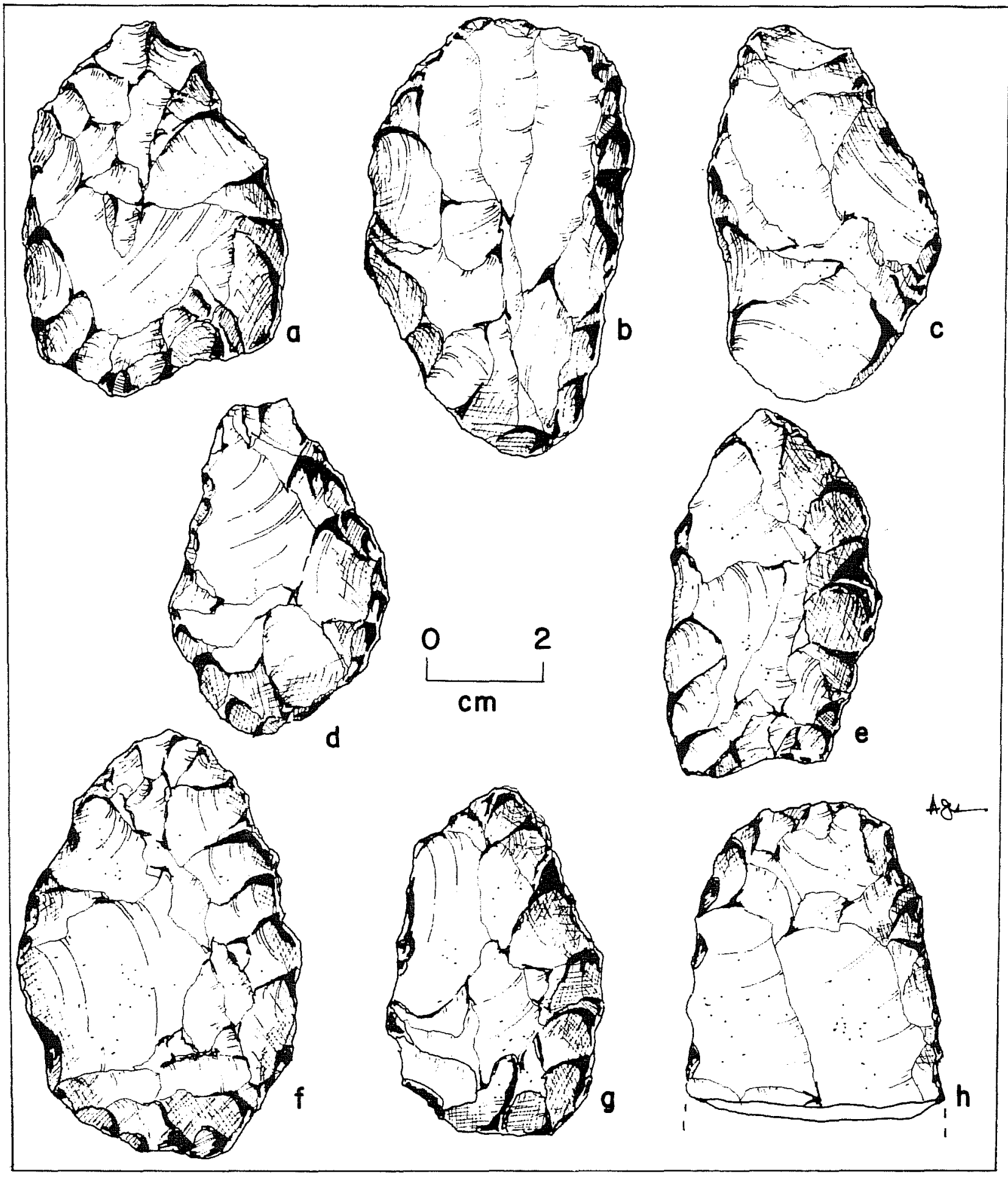

Figure 26. Biface Groups. a-c, Group 2, Form 2 (subdiscoidal, transitional [to ovate]); d,e, Group 3, Form 1 (ovate, el7iptical; compact); f-h, Group 3, Form 2 (ovate). 
TABLE 9. PROVENIENCE AND COMMENTS, GROUP 3, FORM 2 SPECIMENS

\begin{tabular}{|c|c|c|c|}
\hline Specimen No. & Site & Collection & Comments \\
\hline 1 & 41 WB 15 & southern locus & $\begin{array}{l}\text { minute edge step fracturing; edge } \\
\text { dulling }\end{array}$ \\
\hline 2 & 41 WB 15 & southern locus & trimmed flake \\
\hline 3 & 41 WB 15 & northern locus & $\begin{array}{l}\text { semi-invasively retouched on } \\
\text { dorsal edges }\end{array}$ \\
\hline 4 & 41 WB 15 & northern locus & retouched on dorsal edges \\
\hline 5 & 41 WB 15 & southern locus & composite tool \\
\hline 6 & 41 WB 15 & southern locus & semi-invasive dorsal retouch \\
\hline 7 & 41 WB 15 & southern locus & invasively retouched \\
\hline 8 & 41 WB 15 & southern locus & $\begin{array}{l}\text { distal end semi-invasively } \\
\text { retouched }\end{array}$ \\
\hline 9 & 41 WB 15 & southern locus & $\begin{array}{l}\text { end and edges semi-invasively } \\
\text { retouched }\end{array}$ \\
\hline 10 & 41 WB 16 & surface & composite tool \\
\hline 11 & 41 WB 16 & surface & $\begin{array}{l}\text { distal end is semi-invasively } \\
\text { retouched }\end{array}$ \\
\hline 12 & 41 WB 16 & surface & $\begin{array}{l}\text { edge abrasion, minute step } \\
\text { fracturing }\end{array}$ \\
\hline
\end{tabular}


Form 3 (seven specimens; Fig. 27,a-c)

Although ovate, the edges of these artifacts are well defined, and the working edge is often a distinct morphological feature. Measurement range: L: 3.4$6.6 ; \mathrm{W}: 3.3-4.7 ; \mathrm{T}: 1.0-1.45$. See Table 10 for provenience data. Specimens 2 and 3 (Fig. 27,b and C) are similar to the Nueces scraper type as defined by Hester, White, and White (1969) but are more triangular, with the working end steeply retouched with angles of ca. $65^{\circ}$. Plano-convex in cross section, the working edges are straight. Ventral edges of working ends are characterized by nicking, minute step fracturing, and invasive breaks along dorsal edges. They are similar to "Lunate Scrapers" as discussed by Hester, White, and White (1969).

Group 4. Triangular (37 specimens)

Form 1, tentative form (nine specimens; Fig. 27,d-f)

These specimens have a narrow triangular blade, a convex proximal end, and a trapezoidal cross section. This group also contains a number of triangular fragments, 111 with narrow blades and moderately to steeply angled convex ends. Measurement range: $L$ : indeterminate; $W: 2.6-3.5 ; T: 0.6-1.4$. See Table 11 for provenience and comments.

Form 2, tentative form (14 specimens; Fig. 27,g-i)

These artifacts are triangular with a wide blade and moderate to steeply angled convex ends. They are plano-convex to trapezoidal in cross section. Measurement range: $L: 6.9-7.9 ; \mathrm{W}: 3.6-7.8 ; \mathrm{T}: 0.5-1.7$. See Table 12 for provenience and comments regarding these specimens.

Form 3 (eight specimens; Fig. 28,a-c)

These specimens have a triangular, uncurved proximal end and a trapezoidal cross section. All artifacts were collected from the surface. Refer to Table 13 for distributions of this form. All specimens reflect light to moderate percussion flaking and some basal thinning. Blade edges are often pressure flaked. Two specimens (Fig. 28,a and C, respectively) are lightly fire reddened. Measurement range: $L:$ indeterminate; $W: 2.8-4.1 ; T: 0.4-5.1$.

Form 4 (five specimens; Fig. 28,d-f)

These artifacts exhibit a triangular, uncurved proximal end; an expanding blade; and are trapezoidal in cross section. Measurement: $L$ : indeterminate; $W$ : 4.14.7; T: 0.8-1.0. See Table 14 for provenience data and comments. 


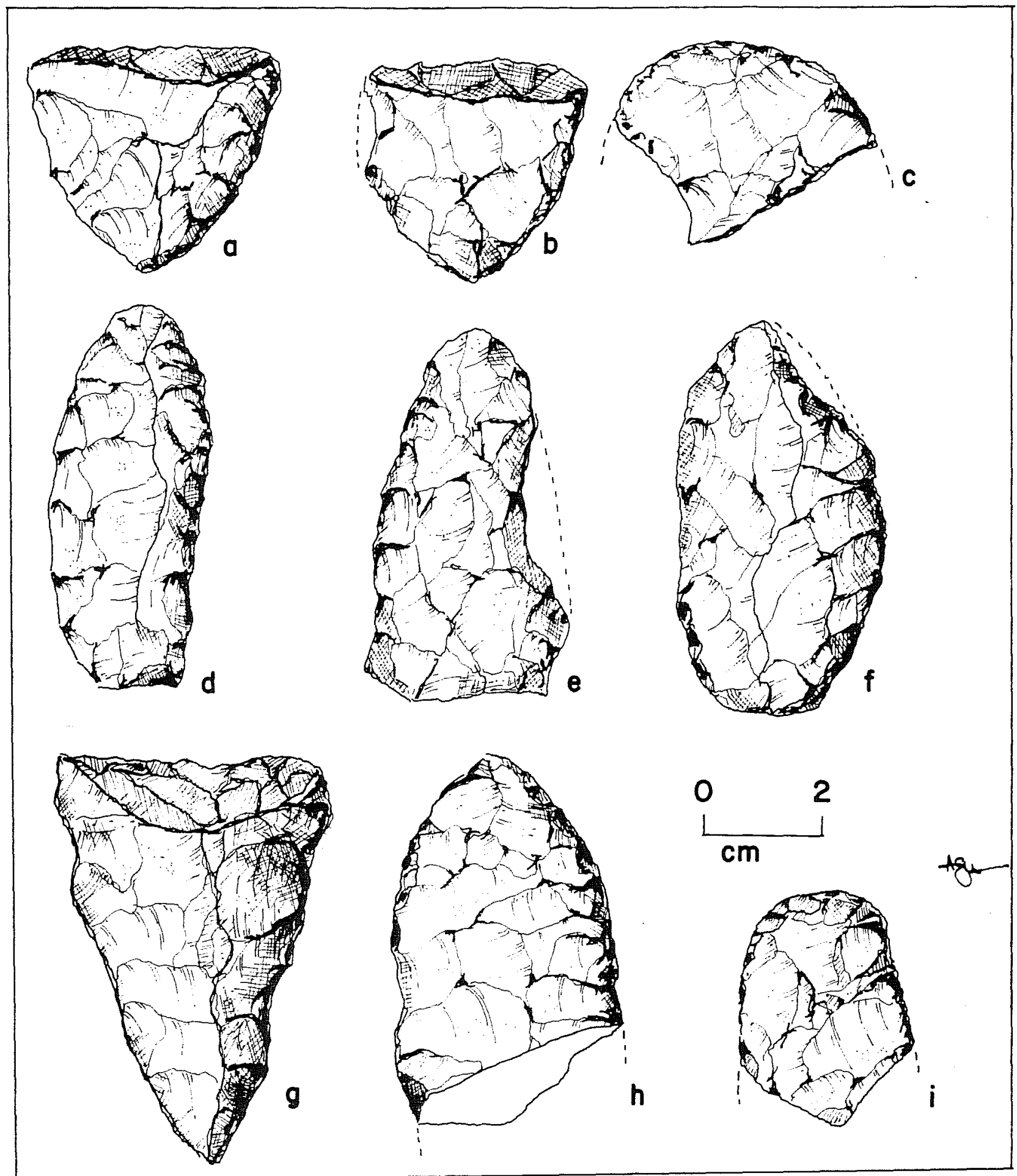

Figure 27. Biface Groups. a-c, Group 3, Form 3 (ovate, elliptical, transitional); d-f, Group 4, Form 1 (triangular); g-i, Group 4, Form 2 (triangular). 
TABLE 10. PROVENIENCE AND COMMENTS, GROUP 3, FORM 3 SPECIMENS

\begin{tabular}{clll} 
Specimen No. & Site & Collection & Comments \\
\hline 1 & 41 WB 15 & subsurface & smal1 dorsal edge step fractures \\
noted & \\
2 & 41 WB 15 & subsurface & similar to Nueces scraper type \\
3 & 41 WB 15 & subsurface & similar to Nueces scraper type \\
4 & 41 WB 15 & subsurface & overshot flake; includes bit \\
5 & 41 WB 15 & fubsurface & ventral notching \\
6 & 41 WB 15 & subsurface & composite tool \\
7 & 41 WB 17 & subsurface & prominent dorsal ridge; steep \\
& & & edge/ridge angles
\end{tabular}


TABLE 11. PROVENIENCE AND COMMENTS, GROUP 4, FORM 1 SPECIMENS

\begin{tabular}{clll} 
Specimen No. & Site & Collection & Comments \\
\hline 1 & 41 WB 13 & surface & ventral marginal retouch \\
2 & 41 WB 15 & surface & possible preform fragment \\
3 & 41 WB 15 & surface & marginal retouch, dorsal surfaces \\
4 & 41 WB 15 & surface & dorsal marginal retouch \\
5 & 41 WB 15 & surface & dorsal end retouch \\
6 & 41 WB 15 & surface & dorsal and ventral semi-invasive \\
7 & 41 WB 15 & surface & fire reddened \\
8 & 41 WB 15 & surface & preformlike artifact \\
9 & 41 WB 15 & $\begin{array}{l}\text { Test Unit } 1, \\
\text { Level } 2 \\
(10-20 \mathrm{~cm})\end{array}$ &
\end{tabular}


TABLE 12. PROVENIENCE AND COMMENTS, GROUP 4, FORM 2 SPECIMENS

\begin{tabular}{|c|c|c|}
\hline Specimen No. & Site & Collection \\
\hline 1 & 41 WB 15 & surface \\
\hline 2 & 41 WB 15 & surface \\
\hline 3 & 41 WB 15 & surface \\
\hline 4 & 41 WB 15 & surface \\
\hline 5 & 41 WB 14 & $\begin{array}{l}\text { Test Unit } 1 \text {, } \\
\text { Leve1 } 3 \\
(20-30 \mathrm{~cm})\end{array}$ \\
\hline 6 & 41 WB 15 & surface \\
\hline 7 & 41 WB 15 & surface \\
\hline 8 & 41 WB 15 & surface \\
\hline 9 & 41 WB 15 & surface \\
\hline 10 & 41 WB 15 & surface \\
\hline 11 & 41 WB 16 & surface \\
\hline 12 & 41 WB 16 & surface \\
\hline 13 & 41 WB 17 & surface \\
\hline 14 & 41 WB 17 & surface \\
\hline
\end{tabular}

Comments

Clear Fork tool

possible preform

possible preform

utilized; marginal retouch

preform

worked from dark metamorphic (possibly igneous) material dorsal retouch along one edge dorsal retouch along one edge dorsal retouch along one edge minute step fracturing along edges suggests utilization

step fracturing along ventral edges

marginal retouch on dorsal and ventral faces 


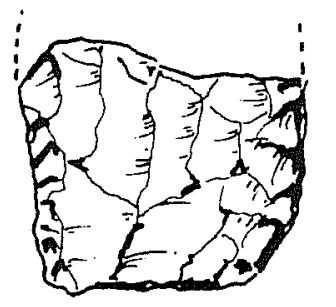

a
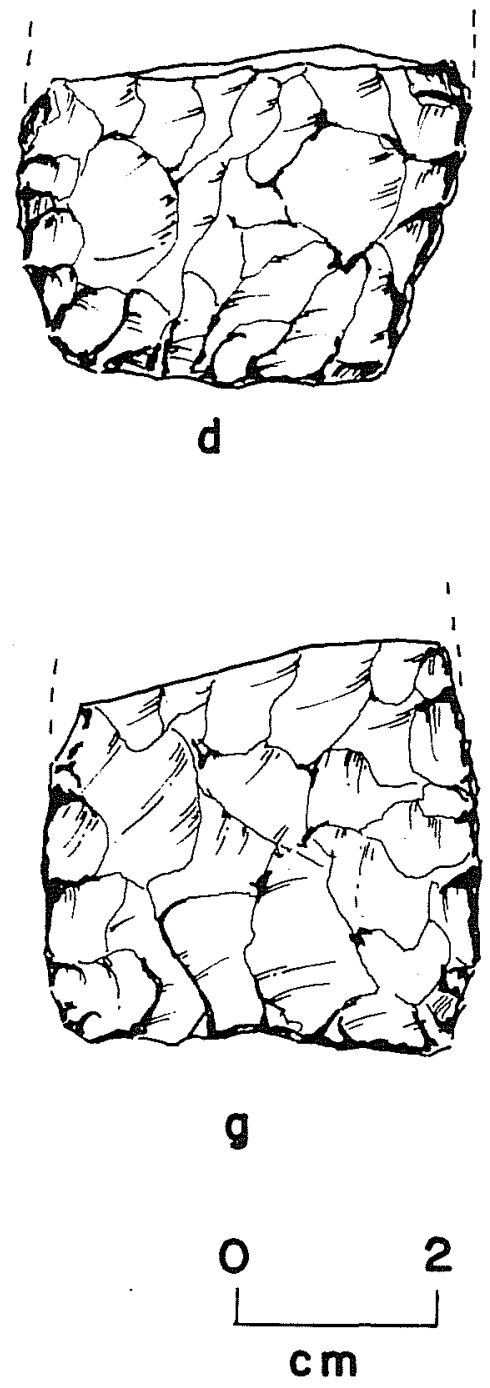

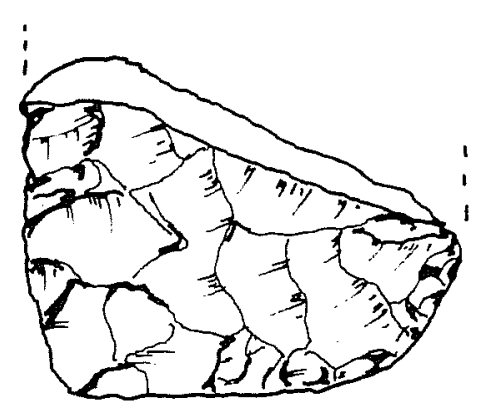

b
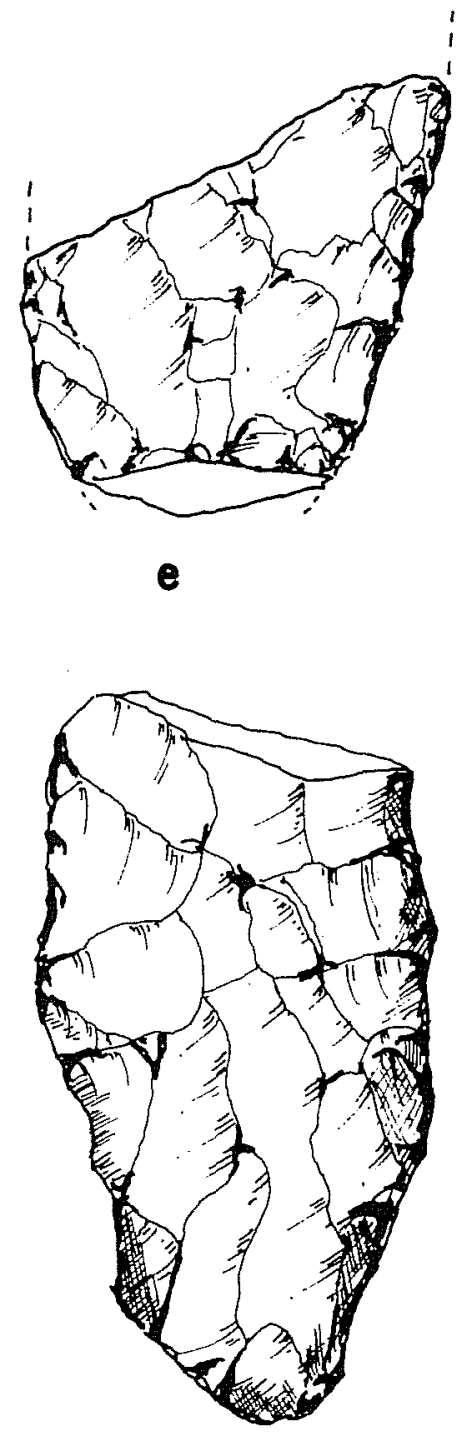

h

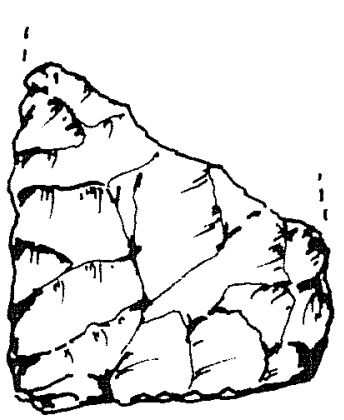

C
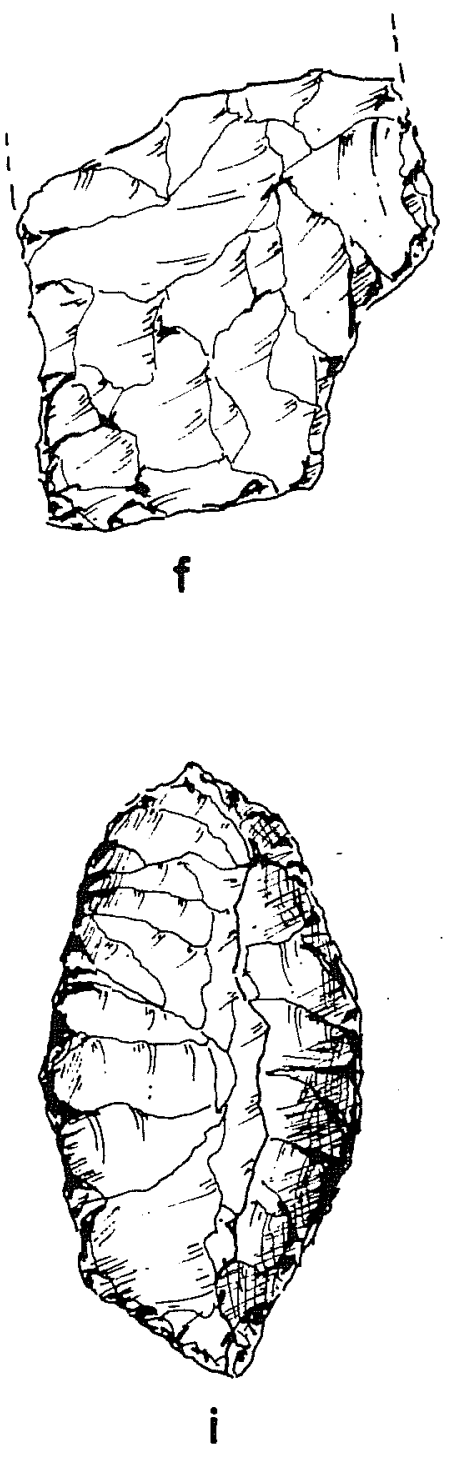

Figure 28. Biface Groups. a-c, Group 4, Form 3 (triangu7ar); d-f, Group 4, Form 4 (triangular); g, Group 4, Form 5 (triangular); $h-i$, Group 5, Form 1 , (lanceolate). 
TABLE 13. SUMMARY OF BIFACE PROVENIENCE

41 WB $13 \quad 41$ WB 15 41 WB 16 41 WB 17 41 WB 18 41 WB 20 TOTAL

Group I

Form 1

$4 \quad 2$

7

Form 2

4

5

Group 2

Form 1

3

31

2

9

Form 2

5

5

Group 3

Form 1

Form 2

1

11

2

Form 3

9

2

12

Form 3

6

1

7

Group 4

$\begin{array}{lll}\text { Form } 1 & 1 & 8\end{array}$

9

Form 2

10

2

2

14

Form 3

3

1

8

Form 4

3

5

Form 5

1

1

Group 5

Form 1

5

5

Form 2

2

1

1

5

TOTAL

15

62

9

4

3

94 
TABLE 14. PROVENIENCE AND COMMENTS, GROUP 4, FORM 4 SPECIMENS

Specimen No.

Site

Collection

Comments

\begin{tabular}{|c|c|c|c|}
\hline 1 & 41 WB 13 & surface & expanding blade \\
\hline 2 & 41 WB 13 & surface & basally thinned \\
\hline 3 & 41 WB 15 & surface & $\begin{array}{l}\text { fire reddened; } \\
\text { basally thinned }\end{array}$ \\
\hline 4 & 41 WB 15 & surface & basally thinned \\
\hline 5 & 41 WB 15 & surface & expanding blade \\
\hline
\end{tabular}

Form 5, tentative form (one specimen; Fig. 28,g)

This specimen is triangular with a concave base. It was surface collected from 41 WB 12. The artifact is extremely thin with parallel-bladed edges. It is basally thinned, and blade edges are alternately beveled. L: 4.1; W: 4.4; $\mathrm{T}: 0.75$.

Group 5. Lanceolate (10 specimens)

Form 1 (five specimens; Fig. $28, h-i$ )

These specimens exhibit wide blades (more than $3.5 \mathrm{~cm}$ in width). The specimens were collected from the surface of 41 WB 15. Three of these specimens show no use-wear; the other two specimens appear to be unfinished preforms with minute step fractures along the dorsal edges. L (maximum): 8.4 (minimum length indeterminate because of fragments); $W: 3.5-4.3 ; \mathrm{T}: 1.2-1.5$.

Form 2 (five specimens)

These artifacts have lanceolate, narrow blades (less than $3.5 \mathrm{~cm}$ wide). Specimens 1 and 2 were collected from 41 WB. 13, Specimen 3 from 41 WB 16, Specimen 4 from 41 WB 17, and Specimen 5 from 41 WB 18. All artifacts have parallel or approximately parallel blade edges. Specimens 1, 2, and 3 have burinlike projections along the distal ends. A11 are plano-convex in cross section, and blade edge angles are greater than $45^{\circ}$. Specimen 1 exhibits minute step fractures along edges, but this may be due to processes involved in shaping as wel1 as use. Measurement range: L: 4.9-6.4; W: 2.7-3.4; T: 0.7-1.4.

Tools Classified by Identifiable Working Edges

Fifteen artifacts (Figs. 29, 30) were identified as having multiple working edge angles. The distribution of these artifacts and their frequencies of relative composite angles are presented in Figure 31. 

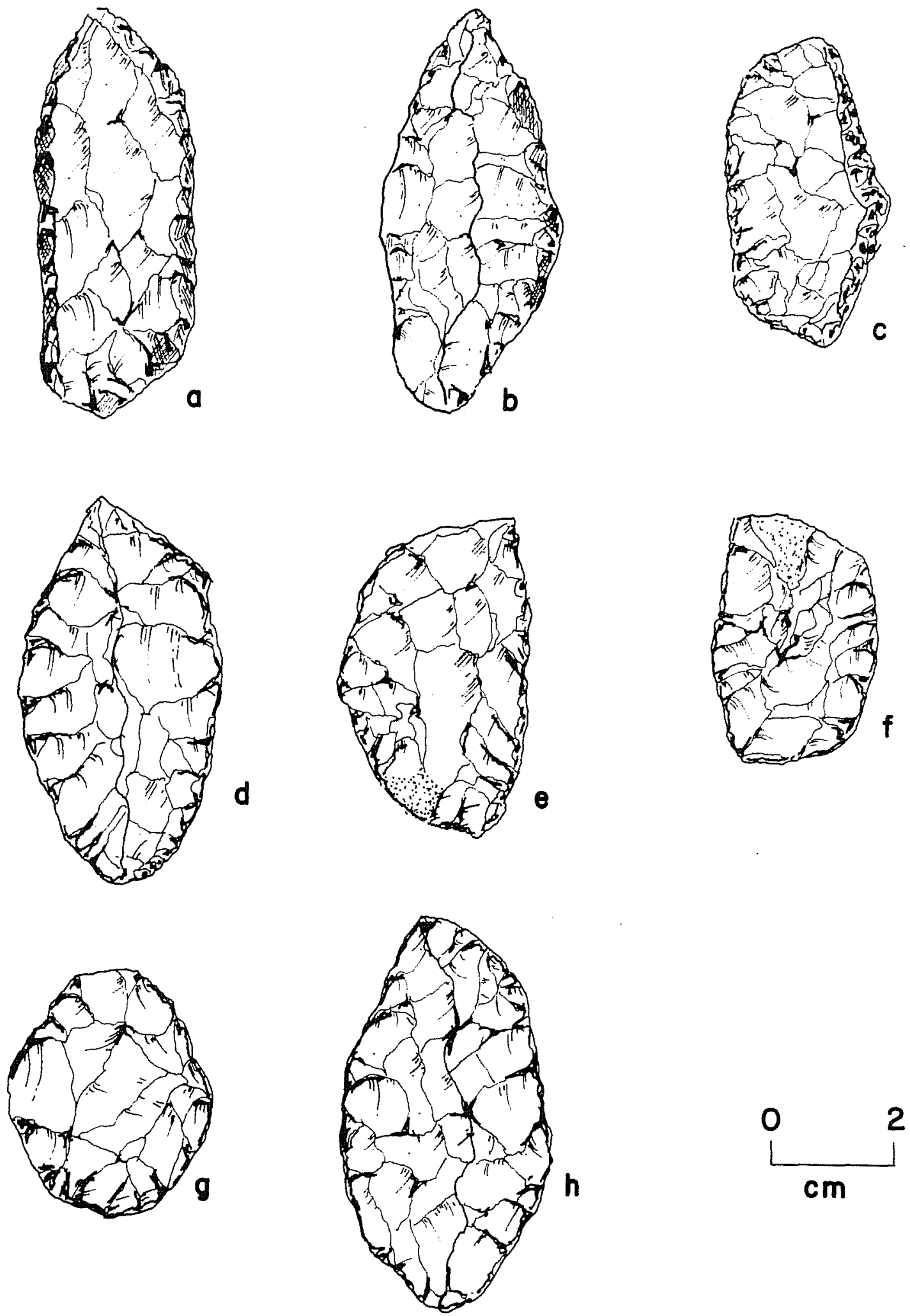

Figure 29. Composite Bifaces. a-h, from site 41 WB 15. 

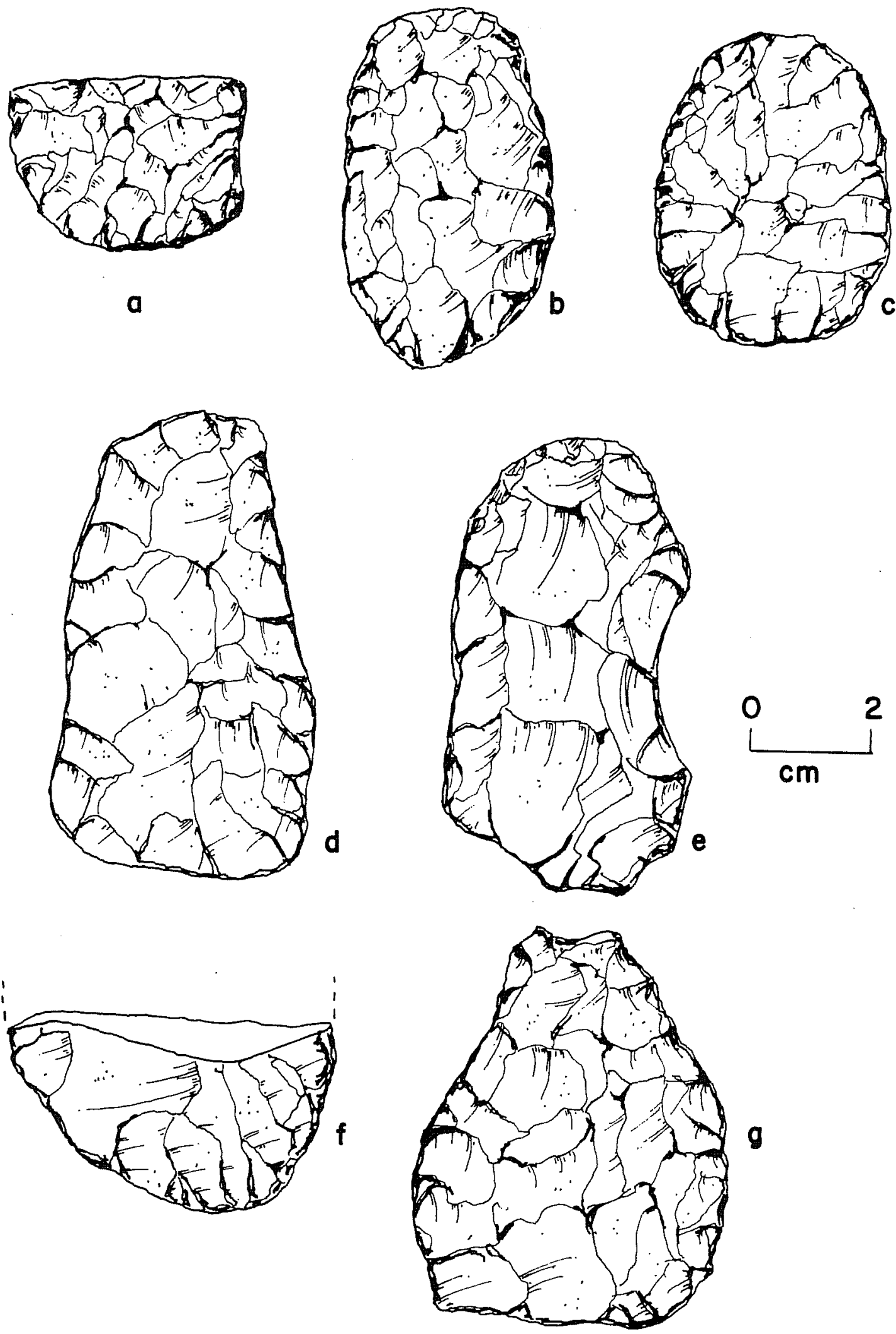

Figure 30. Composite Bifaces, a-d, from site 41 WB 16; e,f, from site 41 WB 18; $g$, from site 41 WB 20. 


\section{LAREDO WATER WORKS PROJECT}

COMPOSITE ANGLED BIFACES

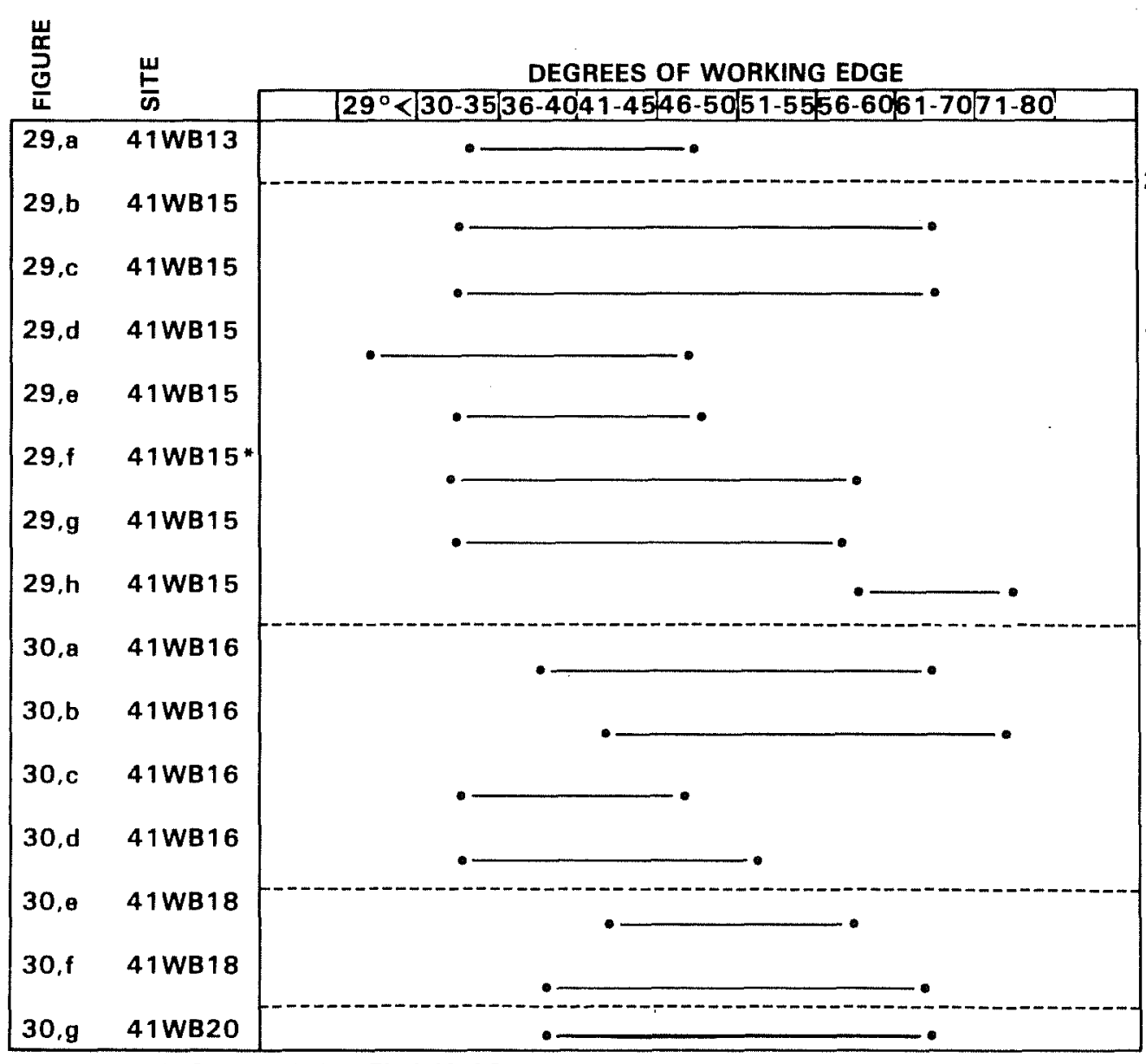

* TEST PIT 1, LEVEL $1(0-10 \mathrm{~cm})$

ALL MATERIAL FROM SURFACE COLLECTIONS UNLESS NOTED.

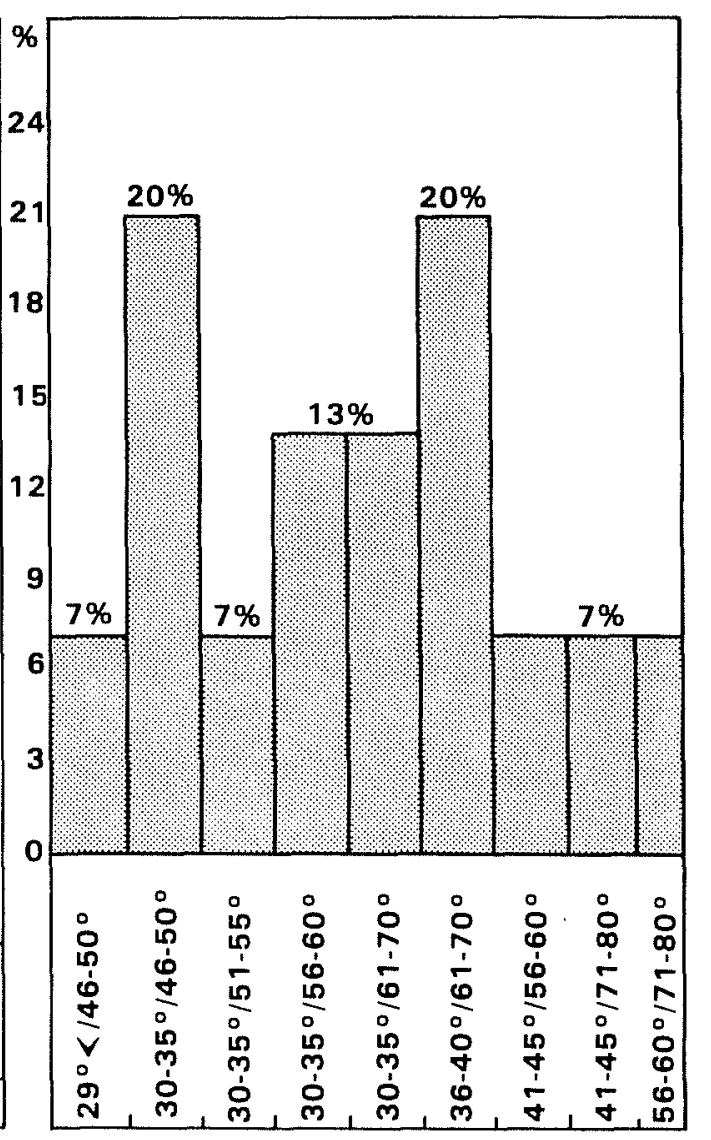

FREQUENCY OF COMPOSITE ANGLES ON LITHIC ARTIFACTS $\mathrm{N}=15$

Figure 31. Distribution of Working Edge Angles, Composite Bifaces: 
These artifacts, collected from several different sites and having varying morphologies, share the common characteristic of multiple working edges. A preliminary examination suggests that specific tool forms distinguished by compound edge angles may exist within this rather inclusive category. In an attempt to further define similar traits, these artifacts were divided into groups of similar angles: (1) less than $29^{\circ}$, (2) $30-35^{\circ}$, (3) $36-40^{\circ}$, (4) $41-$ $45^{\circ}$, (5) $46-50^{\circ},(6) 51-55^{\circ}$, (7) $56-60^{\circ}$, (8) $61-70^{\circ}$, and (9) $71-90^{\circ}$ (Fig. 32 ).

The accompanying histogram (in Fig. 31) suggests a high correlation between the dorsal working edge angles of ca: $30-35^{\circ}$ and $40-50^{\circ}$, as well as those of $36-40^{\circ}$ and $61-70^{\circ}$. This may suggest that shallow working edge angles (often associated with cutting activities) are functionally related to moderate scraping activities; i.e., tools with a steeper angle are more suitable for heavier pressure wear and/or utilization. Composite tools from the study area suggest that these tools usually do not reflect shallow working edge angles associated with steep edge angles. However, these are assumptions based on ly on the limited sample available; more detailed studies of larger collections will do much to further define these preliminary observations.

\section{Lithic Debris}

Lithic debris in the form of primary, secondary, and tertiary flakes, corticate and decorticate chips, chunks, core fragments, and various utilized categories of the former groups were collected from surface and subsurface examinations throughout the study area. The distribution, size, density, and other characteristics of these materials often present insights into prehistoric activity areas, tool production techniques, and usages.

Debris is defined as the waste products from the manufacture or retouch of siliceous stone tools. The local source for such materials is assumed to be the bed and banks of the Rio Grande or upland gravel outcroppings. While a detailed discussion of lithic reduction processes and techniques is beyond the scope of this report, definitions and relevant lithic characteristics will be briefly discussed.

Lithic artifacts were cleaned, categorized, and then separated into various groups for further work. Flakes are detached pieces of siliceous stone fragments possessing both remnants of a striking platform and a bulb of percussion. Primary flakes have an exterior (dorsal) surface completely covered by cortex; secondary flakes retain only partial cortex; and tertiary flakes, struck from the interior of the raw material, retain no cortex on the dorsal face. Siliceous stone fragments, which are basically flake fragments but do not possess a bulb of percussion or platform remnant, were classified as chips or chunks. Primary and secondary flakes were noted per unit level.

Cores were also sorted, and estimates were made of core type, flaking pattern, secondary usage (utilization, if definable), and presence or absence of cortex. Core characteristics are summarized in Table 15, and cores are illustrated in Figure 33. A brief description of collected 1ithic debris is presented in Table 12. 
LAREDO WATER WORKS PROJECT

COMPARISON OF MORPHOLOGICAL BIFACE GROUPS WITH WORKING EDGE ANGLES. PERCENTS ARE ROUNDED TO NEAREST WHOLE.

P $100 \quad$ ANGLES. PERCENTS ARE ROUNDE

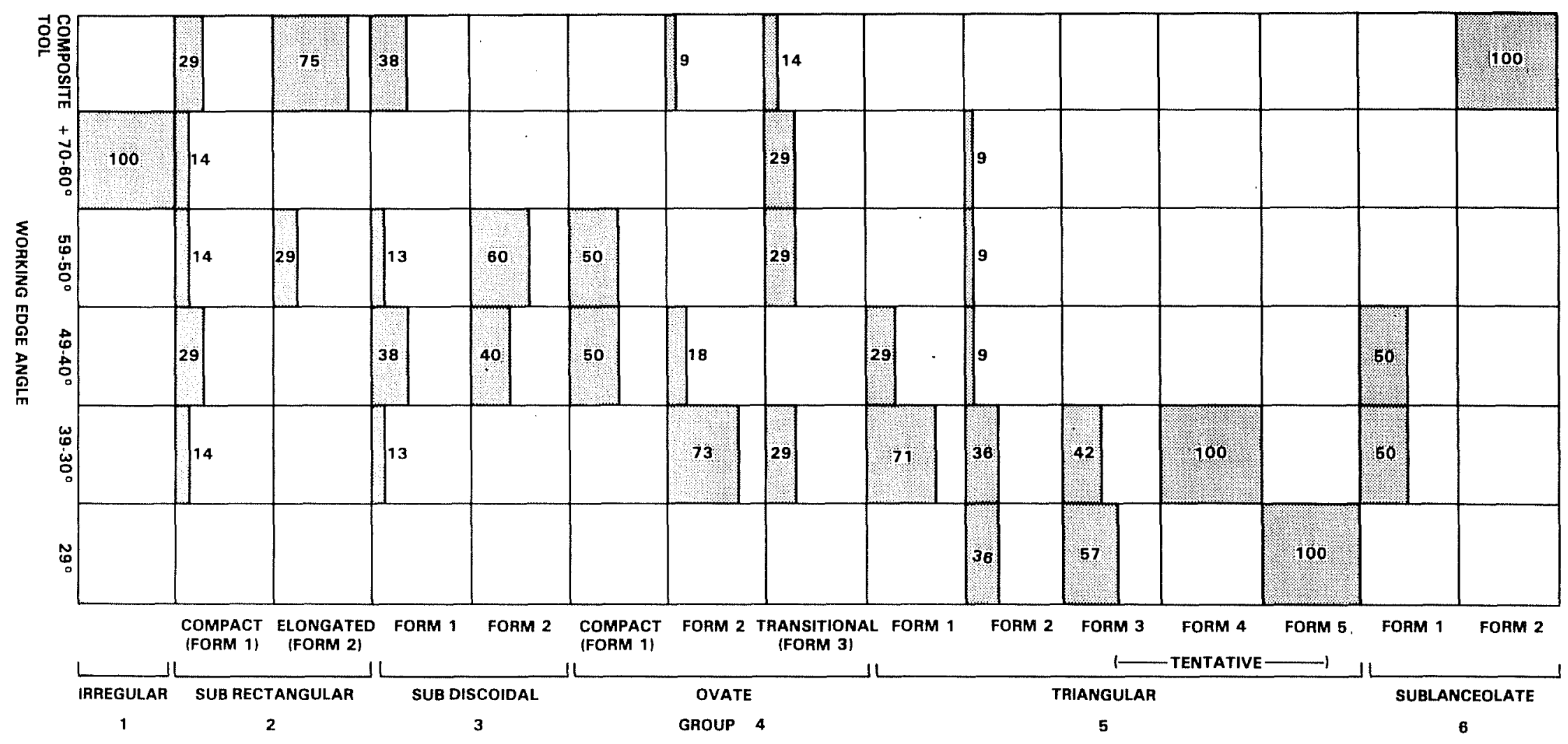

Figure 32. Comparison of Morphological Biface Groups with Working Edge Angles. 
TABLE 15. CORE CHARACTERISTICS

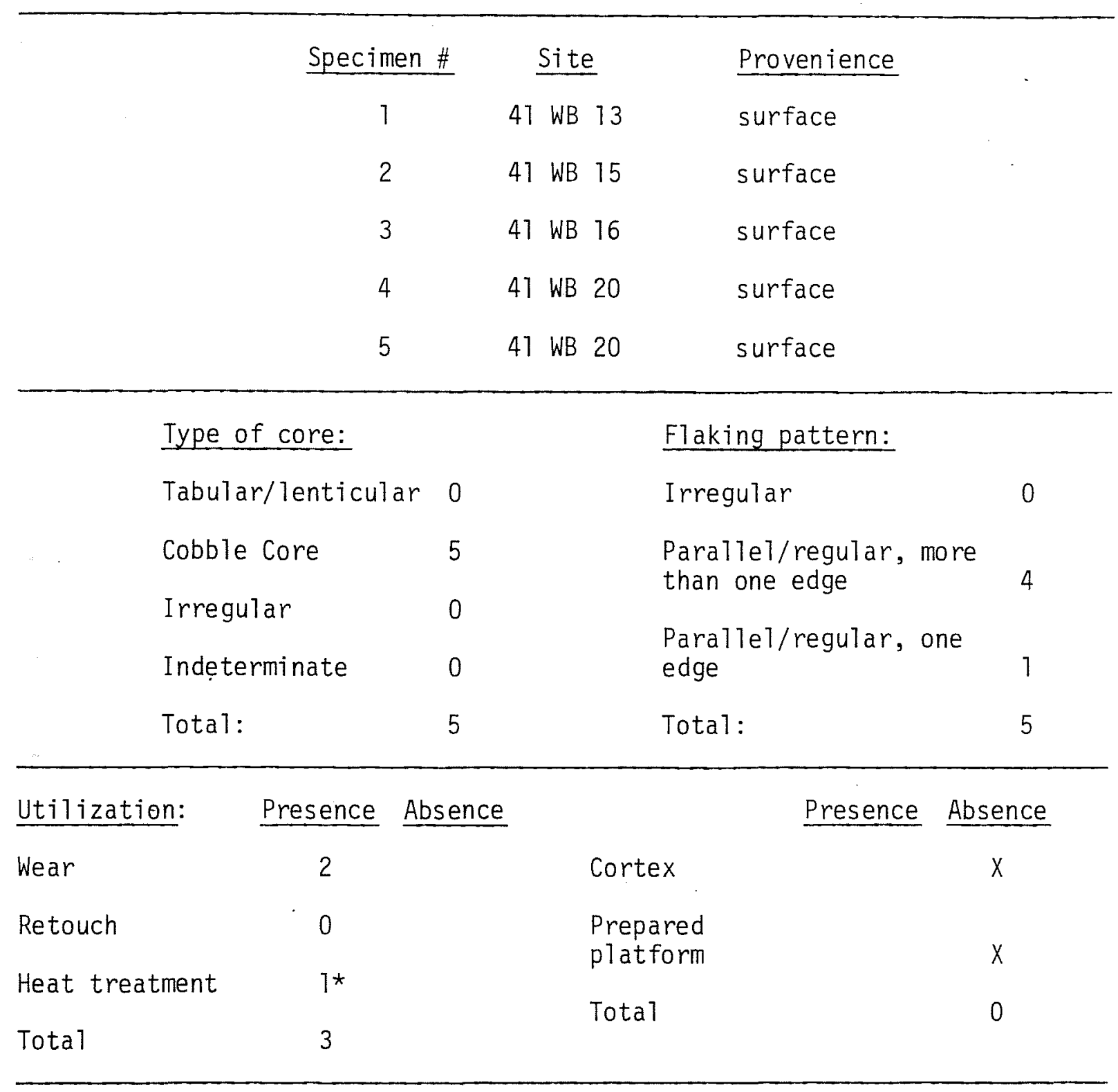

*Fire reddened. 


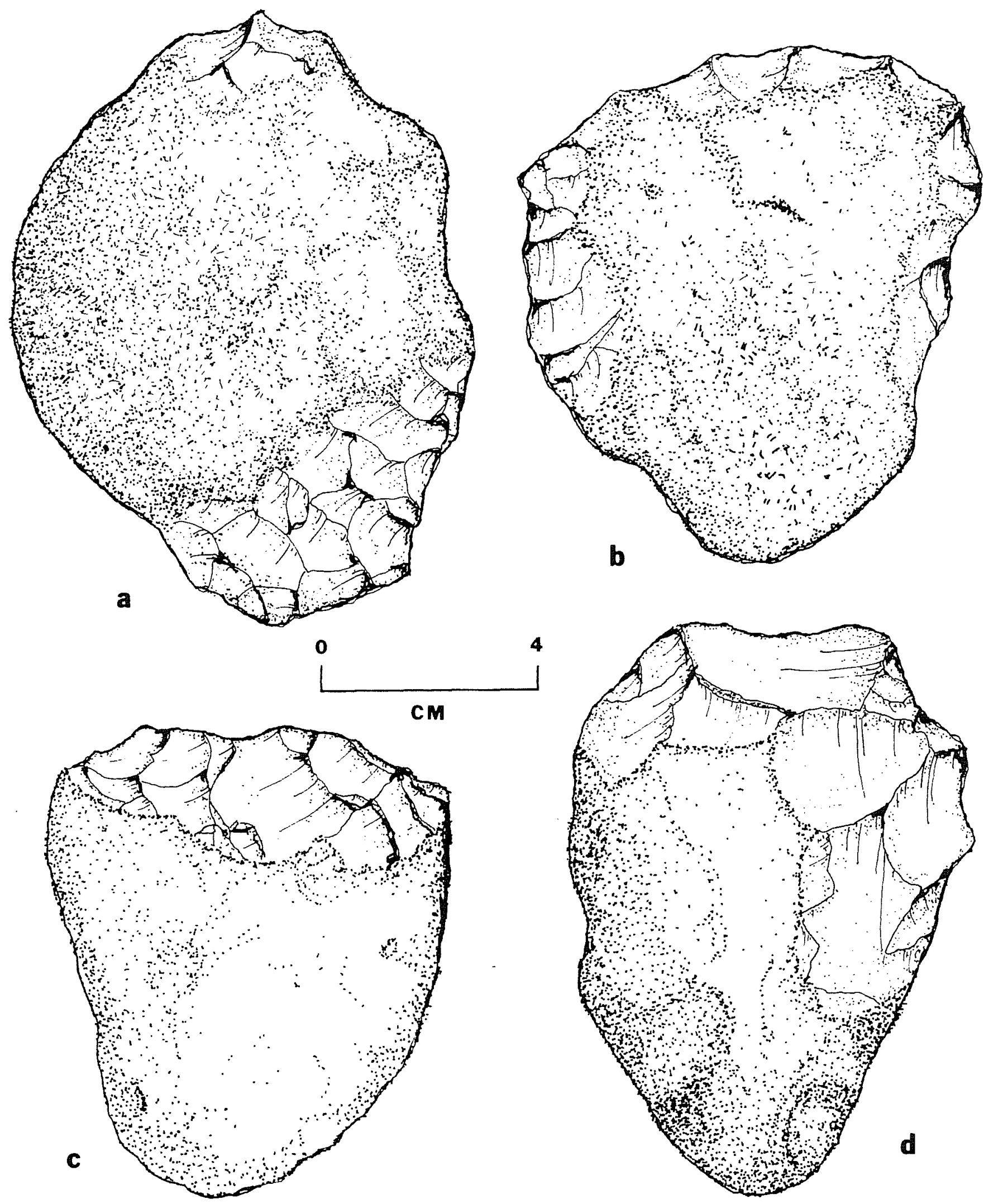

Figure 33. Collected Cores 


\section{TABLE 16. DISTRIBUTION OF LITHIC DEBRIS FROM HAND-EXCAVATED UNITS ${ }^{\dagger}$}

\begin{tabular}{|c|c|c|c|c|c|c|c|c|c|}
\hline \multirow[b]{2}{*}{ Provenience } & \multicolumn{3}{|c|}{ Flakes } & \multicolumn{2}{|c|}{ Chips } & \multicolumn{3}{|c|}{ other } & \multirow[b]{2}{*}{ Tota] } \\
\hline & Primary & Secondary & Tertiary & Decorticate & Corticate & Chunks & Utilized & Cores & \\
\hline $\begin{array}{l}41 \text { WB } 13 \\
\text { Surface }\end{array}$ & & & & & & & & 1 & 1 \\
\hline $\begin{array}{l}\text { Test Unit 1 } \\
\text { Leve1 ] }(0-20 \mathrm{~cm})^{\star} \\
\text { Level } 2(20-30 \mathrm{~cm}) \\
\text { Level } 3(30-40 \mathrm{~cm}) \\
\text { Level } 4(40-50 \mathrm{~cm})\end{array}$ & & & 7 & $\begin{array}{l}2 \\
5\end{array}$ & $\begin{array}{l}1 \\
1\end{array}$ & & & & $\begin{array}{r}0 \\
1 \\
2 \\
13\end{array}$ \\
\hline $\begin{array}{l}\text { Test Unit } 2 \\
\text { Level } 1(0-30 \mathrm{~cm}) \\
\text { Level } 2(30-40 \mathrm{~cm}) \\
\text { Level } 3(40-50 \mathrm{~cm})\end{array}$ & & 1 & $\begin{array}{l}1 \\
6 \\
2\end{array}$ & $\begin{array}{l}5 \\
5 \\
1\end{array}$ & $\begin{array}{l}2 \\
1\end{array}$ & 1 & & & $\begin{array}{r}9 \\
12 \\
5\end{array}$ \\
\hline Total 41 WB 13 & 0 & 2 & 16 & 18 & 5 & 1 & 0 & 1 & 43 \\
\hline $\begin{array}{l}41 \text { WB } 15 \\
\text { Surface }\end{array}$ & & & & & & & & 1 & 1 \\
\hline $\begin{array}{l}\text { Test Unit } 1 \\
\text { Level } 1(0-10 \mathrm{~cm}) \\
\text { Level } 2(10-20 \mathrm{~cm}) \\
\text { Level } 3(20-30 \mathrm{~cm}) \\
\text { Level } 4(30-40 \mathrm{~cm}) \\
\text { Level } 5(40-50 \mathrm{~cm})\end{array}$ & 1 & $\begin{array}{r}6 \\
26 \\
6\end{array}$ & $\begin{array}{r}115 \\
153 \\
101 \\
21 \\
31\end{array}$ & $\begin{array}{r}1084 \\
812 \\
997 \\
192 \\
300\end{array}$ & $\begin{array}{l}76 \\
66 \\
56 \\
15 \\
15\end{array}$ & $\begin{array}{r}25 \\
1 \\
21\end{array}$ & $\begin{array}{l}9 \\
1 \\
2 \\
1 \\
1\end{array}$ & & $\begin{array}{r}1315 \\
1060 \\
1183 \\
229 \\
347\end{array}$ \\
\hline Total 41 WB 15 & 1 & 38 & 421 & 3385 & 228 & 47 & 14 & 1 & 4135 \\
\hline $\begin{array}{l}41 \text { WB } 16 \\
\text { Surface }\end{array}$ & & & & & & & & 1 & 1 \\
\hline Total 41 WB 16 & 0 & 0 & 0 & 0 & 0 & 0 & 0 & 1 & 1 \\
\hline $\begin{array}{l}41 \text { WB } 17 \\
\text { Test Unit 1 } \\
\text { Leve1 } 1(0-30 \mathrm{~cm})^{*} \\
\text { Level } 2(30-40 \mathrm{~cm}) \\
\text { Leve1 } 3(40-50 \mathrm{~cm}) \\
\text { Level } 4(50-60 \mathrm{~cm})\end{array}$ & & & 7 & $\begin{array}{l}6 \\
4 \\
3\end{array}$ & $\begin{array}{l}3 \\
1\end{array}$ & 1 & . & $\cdot$ & $\begin{array}{r}0 \\
17 \\
5 \\
3\end{array}$ \\
\hline $\begin{array}{l}\text { Test Unit } 1 \mathrm{~A}(1 \times 2 \times 2 \\
0-60 \mathrm{~cm}\end{array}$ & & & & 15 & & & & & 15 \\
\hline $\begin{array}{l}\text { Test Unit } 2 \\
\text { Level } 1 .(0-30 \mathrm{~cm}) \\
\text { Level } 2(30-40 \mathrm{~cm}) \\
\text { Level } 3(40-50 \mathrm{~cm})\end{array}$ & $\begin{array}{l}7 \\
2\end{array}$ & $\begin{array}{l}30 \\
23 \\
20\end{array}$ & $\begin{array}{l}176 \\
130 \\
153\end{array}$ & $\begin{array}{l}165 \\
194 \\
184\end{array}$ & $\begin{array}{l}32 \\
45 \\
23\end{array}$ & $\begin{array}{r}7 \\
3 \\
70\end{array}$ & $\begin{array}{l}1 \\
4\end{array}$ & & $\begin{array}{l}418 \\
399 \\
452\end{array}$ \\
\hline Test Unit $3(1.5 \mathrm{x}$ & $0.75 \mathrm{~m})$ & & & & & & & & 0 \\
\hline Total 41 WB 17 & 9 & 73 & 466 & 571 & 104 & 81 & 5 & 0 & 1309 \\
\hline $\begin{array}{l}41 \text { WB } 20 \\
\text { Surface }\end{array}$ & & & & & & & & 2 & 2 \\
\hline $\begin{array}{l}\text { Test Unit } 1(1 \times 2 \\
0-20 \mathrm{~cm}\end{array}$ & & & 4 & & & & & & 4 \\
\hline $\begin{array}{l}\text { Test Unit } 2 \\
\text { Leve] } 1(0-40 \mathrm{~cm})^{\star} \\
\text { Leve] } 2(40-50 \mathrm{~cm})\end{array}$ & & 1 & 2 & & . & 1 & & & $\begin{array}{l}0 \\
4 \\
0\end{array}$ \\
\hline $\begin{array}{lll}\text { Leve1 } & 3 & (50-60 \mathrm{~cm}) \\
\text { Level } & 4 & (60-70 \mathrm{~cm}) \\
\text { Leve] } & 5 & (70-80 \mathrm{~cm})\end{array}$ & STERILE & 4 & 26 & $\begin{array}{r}6 \\
33\end{array}$ & 2 & & 1 & & $\begin{array}{r}0 \\
6 \\
66\end{array}$ \\
\hline Total 41 WB 20 & 0 & 5 & 32 & 39 & 2 & 1 & 1 & 2 & 82 \\
\hline
\end{tabular}

+ A11 units are $2 \mathrm{~m}^{2}$, unless otherwise noted.

* Upper units not excavated, based on examination of adjacent backhoe trenches. 
Ground Stone Materials

Ground stone materials are pieces of stone, often ferruginous, which exhibit, through abrasion, an alteration of original shape, a convexity of one or more faces. These ground stone materials are sometimes referred to as grinding stones or metates. Eight specimens of ground stone were collected during the survey (Table 17; Fig. $34, a-c)$.

TABLE 17. GROUND STONE PROVENIENCE AND DESCRIPTION

Site* Source Material Complete/Fragmentary Surface Abrasion

\begin{tabular}{|c|c|c|c|c|}
\hline 41 WB 13 & Timestone & $x$ & 1 & 2 \\
\hline 41 WB 13 & limestone & $x$ & & $x$ \\
\hline 41 WB 15 & limestone & $x$ & & $x$ \\
\hline 41 WB 15 & Timestone & $X$ (rectangular) & & $x$ \\
\hline 41 WB 15 & limestone & $x$ & $\begin{array}{c}x \text { (possible) } \\
\text { groove })\end{array}$ & \\
\hline 41 WB 16 & 1 imestone & $x$ (ovate) & 1 & \\
\hline 41 WB 17 & 1 imestone & $x$ & $x$ & \\
\hline 41. WB 18 & igneous/basalt(?) & $x$ & $x$ & \\
\hline
\end{tabular}

* Al1 are surface collected.

Bone and She11 Artifacts

Tubutar Bone Beads (not illustrated)

A total of 540 complete and 179 fragmentary bone beads was collected from around the neck and wrists of Burial 1 at 41 WB 20. Two sizes of beads, both relatively sma 11, were noted. Around the neck the beads were smaller than those around the wrist, with an average length of $0.6 \mathrm{~cm}$, an average outside diameter of $0.45 \mathrm{~cm}$, and an inner diameter of 0.29 . Two mussel shell pendants (Fig. 35) were also associated with the beads around the neck.

The 28 beads found around and near the wrist (Fig. 18) were larger, ca. $0.7 \mathrm{~cm}$ in length. Average inner and outer diameters, respectively, were $0.48 \mathrm{~cm}$ and $0.68 \mathrm{~cm}$. One small incised bead was associated with these bracelet materials. 

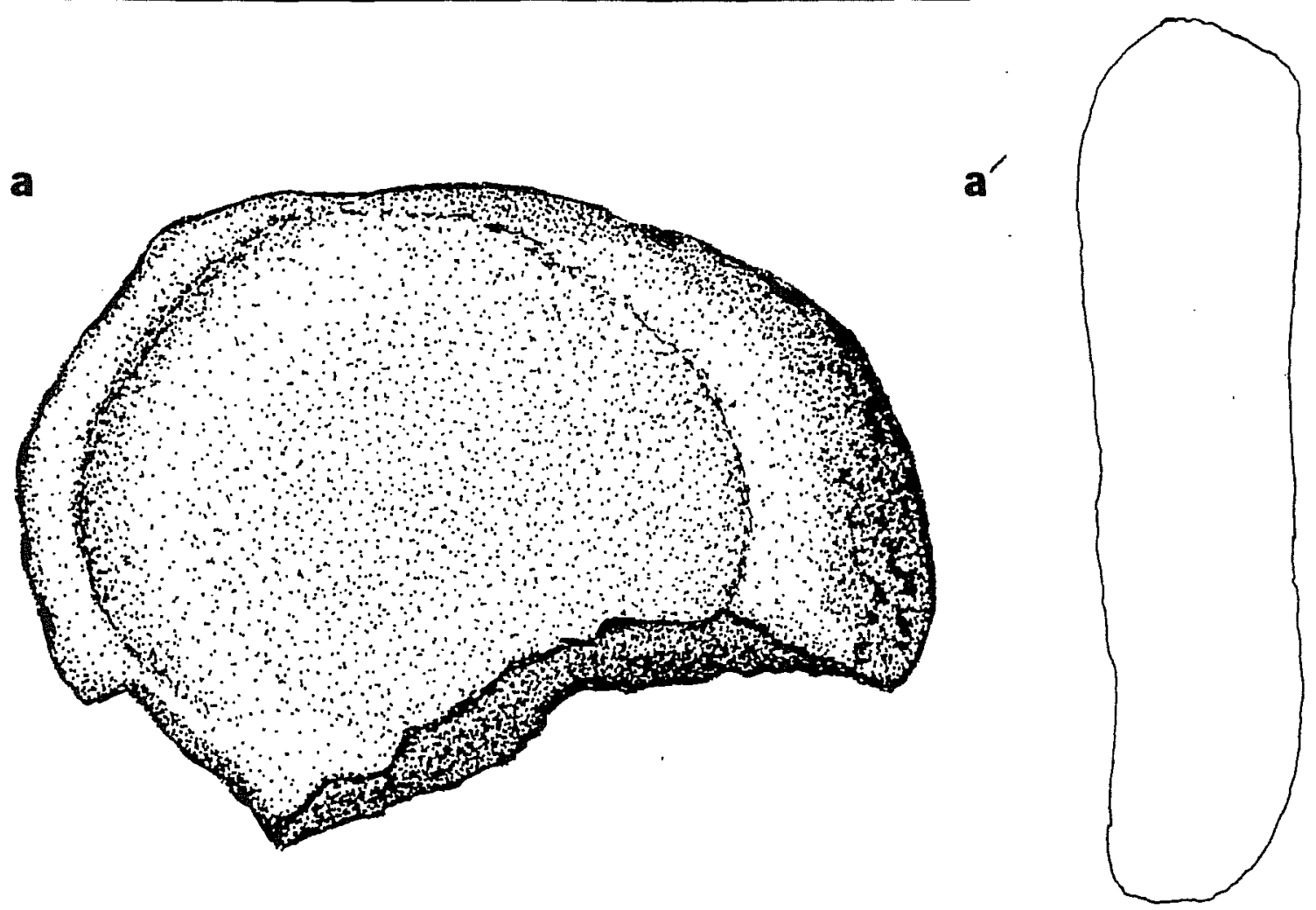

b

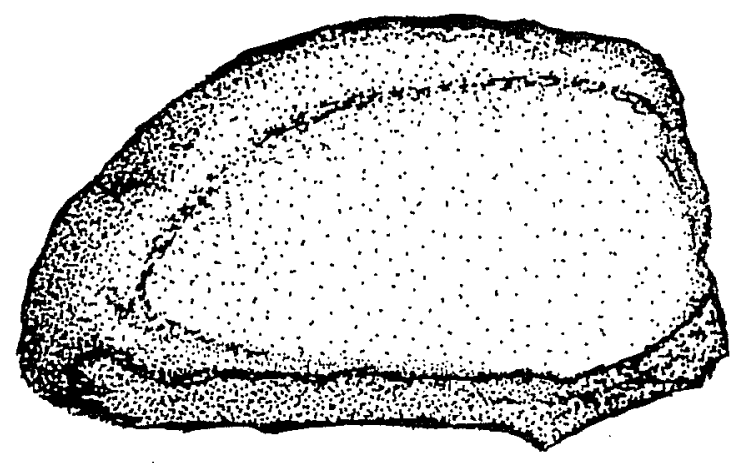

b'

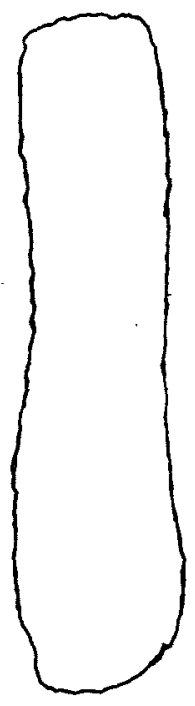

c

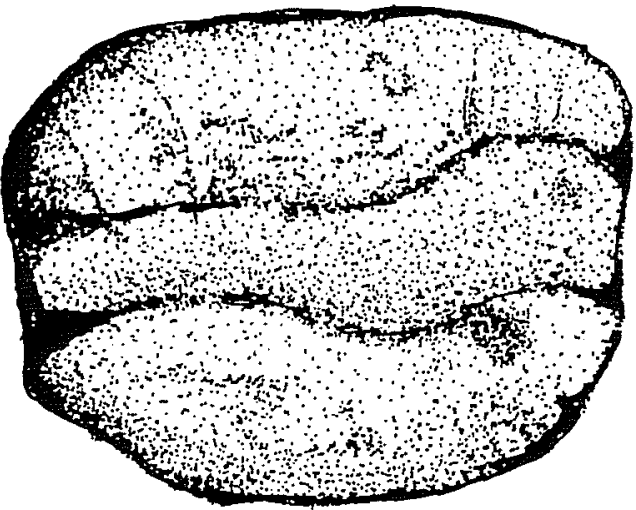

CM

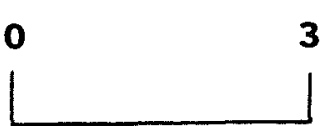

Figure 34. Ground Stone Materials. 

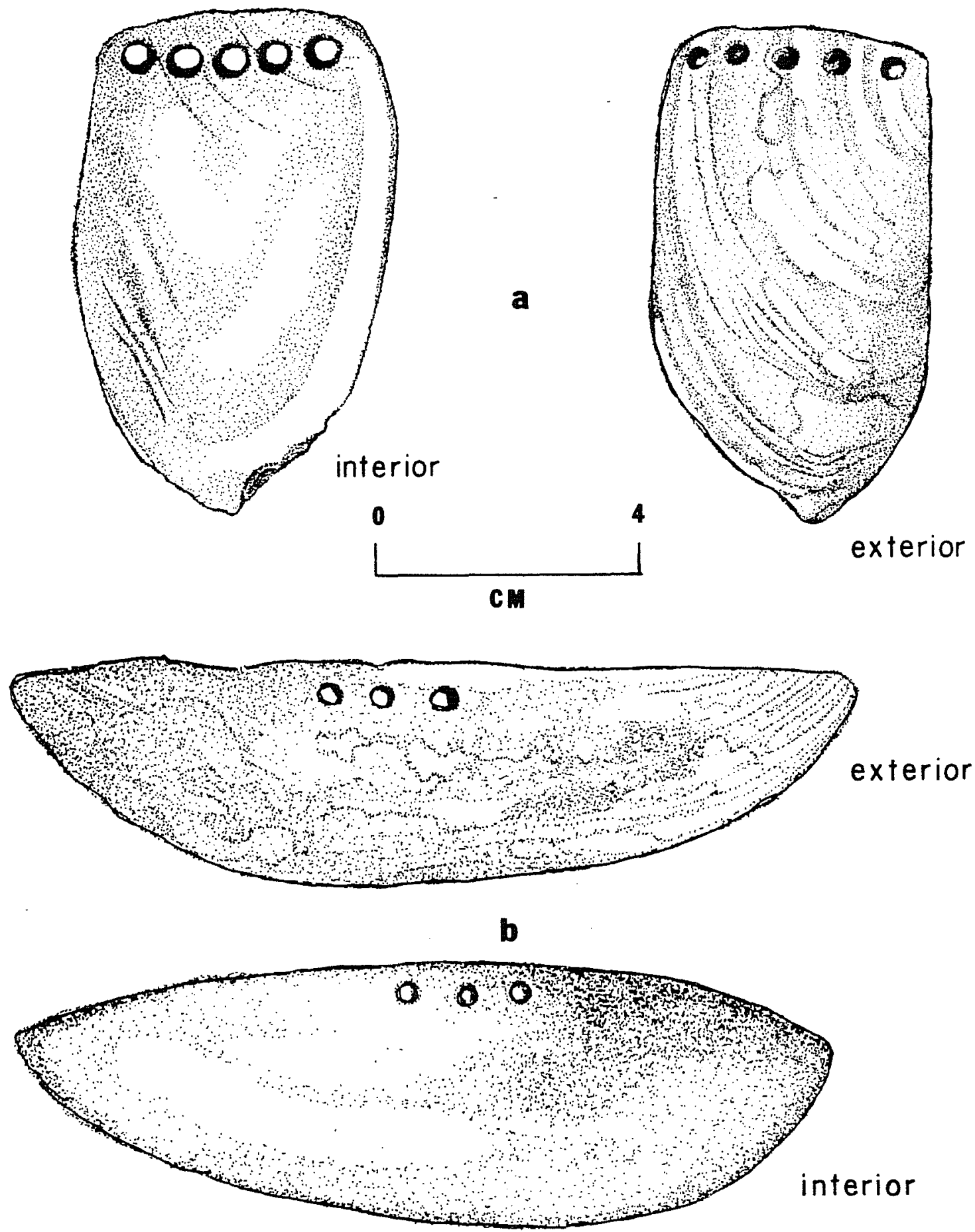

Figure 35. Shell Artifacts from Burial 1, 41 WB 20. 


\section{She1 1 Pendant}

Two mussel shell ornaments (Fig. 35) were associated with Burial 1. Specimen 1 (Fig. 35,a) is $7.5 \mathrm{~cm}$ in length and is perforated by five holes. The holes appear to have been drilled from the interior surface outward. The diameter of the holes is ca. $4 \mathrm{~mm}$. Specimen 2 (Fig. 35,b) has only three perforations; their diameter is also $4 \mathrm{~mm}$.

\section{Prehistoric Ceramics}

Only two prehistoric sherds were recovered from the survey area. Ceramic sherds were distinguished by characteristics of the exterior and interior surfaces. Surface color, texture, evenness of finish, luster, treatment, stroke direction, and porosity were recorded. Surface color was determined macroscopically and confirmed with the use of a variable power stereoscopic microscope at $15 \mathrm{X}$ and $30 x$.

Texture was tactually smooth. The grain size of the paste was defined in relation to the Wentworth scale (Shepard 1976:118). Luster is the description of gloss based upon the extent of burnishing, or polishing. Porosity, the ratio of the volume of pore space to the total volume of the piece, was compacted or noncompacted. Interior sherd characteristics included observations on the extent, color, and type of carbon (core) streak. Paste characteristics included brief descriptions of paste texture (clay substance), paste additions, distributions, inclusions, and uniformity.

Specimen 1 (Fig. 36,a)

Exterior Surface

Color Range: Munsell readings presented as minimum to maximum variations, readings taken dry. Exterior surface: 7.5 YR 7/4. Interior surface:

10 YR $6 / 2-10$ YR $6 / 4$.

Type of Finish: even.

Paste: fine grained.

Luster: slight, opaque.

Filler Protrusions: none.

Surface Treatment: presumed wiping, wet smoothing. Sherd appears to have been brushed; overlain by less distinct but observable wiping marks. No coil lines noted.

Stroke Direction: diagonal (?).

Porosity: compacted. 


\section{Sherd Interior}

Core: carbon streak is off-center, toward exterior wall. Streak consists of ca. 1/2 of total cross section. Core appears well defined and blends gradually into the paste.

Paste (as per 15-30X microscope): paste is dense and compacted. No inclusions noted. Temper appears to be sand.

Provenience: 41 WB 13. Surface collection from southern end of site.

Measurements: L: $5.64 ; \mathrm{W}: 3.92 ; \mathrm{T}: 0.97$.

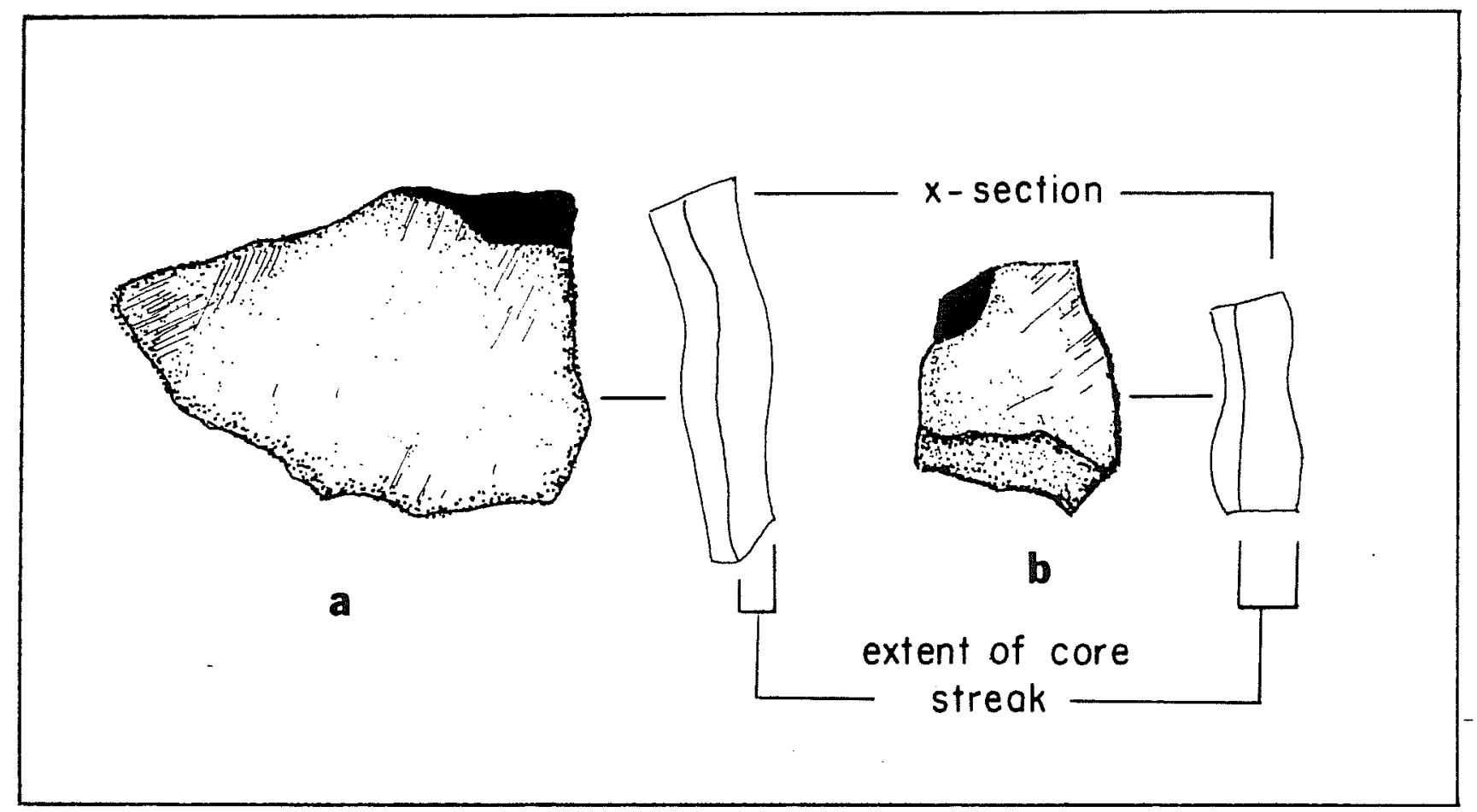

Figure 36. Prehistoric Ceramic Sherds.

Specimen 2 (Fig. 36,b)

Exterior Surface

Color Range: 7.5 YR 6/4-7.5 YR 7/4 (inner surface: 7.5 YR 8/2-7.5 YR 6/4).

Type of Finish: even, no unequal contours.

Texture: tactually smooth, compacted.

Luster: dull, matte finish. 
Filler Protrusions: none.

Treatment: wiping, wet smoothing (brushed?).

Stroke Direction: multidirectional, straight-lined.

Sherd Interion

Core: over $2 / 3$ of the cross section; carbon streak is off-center, toward exterior surface. Core is well defined.

Paste: silty to fine grained. Temper appears to be sand.

Provenience: 41 WB 15. Surface collection, southern end of site.

Measurements: L: 2.98; W: 2.23; T: 0.7-0.96.

Historic Cultural Materials

Historic artifacts were collected from two separate sites, 41 WB 13 and 41 WB 15. These artifacts, dating from the late 19th century through the early 20 th century, were collected from scattered surface contexts. No related subsurface deposits were observed in nearby backhoe trenches, and the materials are presumed to represent intermittent cultural activities. Artifacts were grouped into glass, ceramic, and metal categories and are described in detail by site.

Ceramics (41 WB 13; surface collection)

Earthenware (16 specimens)

Yellowware (one specimen). Rim sherd (not illustrated). Yellow with parallel white bands just below the rim. Yellowware was a durable, mass-produced pottery common in many of the mail-order house catalogs of the 1ate 19th and early 20th century (Raycraft and Raycraft 1975).

Undecorated earthenware (three specimens). White (not illustrated); one rim sherd noted. One specimen has a solid green exterior glaze.

Transfer-printed wares (six specimens). The decorations on transfer-printed wares were applied by thin paper from engraved plates (Schuetz 1969; Scurlock et al. 1976:197-198). The process originated in England in the mid 18th century and became increasingly popular in the later 1800s (Mankowitz and Hagger 1957:224).

Lead-glazed wares (six specimens). Decorated. One specimen, a rim sherd, has a distinct decorative brown band around the rim. Four of the artifacts (Fig. $37, a-d)$ appear to be decorated utilitarian Mexican ware, dating to post-1900. Most of this Mexican pottery can be classified as soft-paste earthenware 
and is difficult to date because of the similarity of manufacturing techniques over a wide period of time (Scurlock et al. 1976:196-197).

Porcelain (four specimens)

Porcelain differs from earthenware by its fine-grained, impenetrable paste and greater hardness. It may be grouped into decorated and nondecorated categories. Two specimens are transfer printed; one specimen (Fig. 37,e) is a decalcomania sherd. The undecorated sherd (not illustrated) presumably is a utility ware.

Stoneware (three specimens; not illustrated)

One specimen appears to have a lusterwarelike glaze. Another specimen has a shiny surface similar to the metal1ic films of lusterware (Godden 1971:108) and is tentatively typed as an Albany-slipped stoneware fragment.

Glass (one specimen; not illustrated)

The glass specimen is pressed and translucent.

Bottle Fragments (four specimens; Fig. $37, f-i$ )

One specimen (Fig. 37,f) is complete. It was manufactured by A. S. Hinds, Portland, Mass., between 1870-1925.

Buttons (two specimens; not i1lustrated)

One shell button and one porcelain button were recovered from $41 \mathrm{WB} 13$. They are associated with late 19 th-century and early 20 th-century cultural contexts.

Metal Artifacts

Bullets (41 WB 13, uncontrolled surface collections)

One bullet, .22 caliber, 26 grains, lead (not illustrated). Bullet diameter $52 \mathrm{~mm}$. Collected from Test Unit $1\left(2 \mathrm{~m}^{2}\right)$, Level $4(30-40 \mathrm{~cm})$.

Three bullets, . 30 caliber, 217 grains, full metal jacket, copper clad. Bullet diameter $73 \mathrm{~mm}$. L: 3.2 .

Two bullets, .45 caliber, 395 grains, lead. Bullet diameter .01 mm. L: 2.85 .

Bullets (41 WB 15, uncontrolled surface collections)

Two bullets, .45 caliber, 484 grains, lead. Bullet diameter $1 \mathrm{~mm}$. L: 3.2 . 


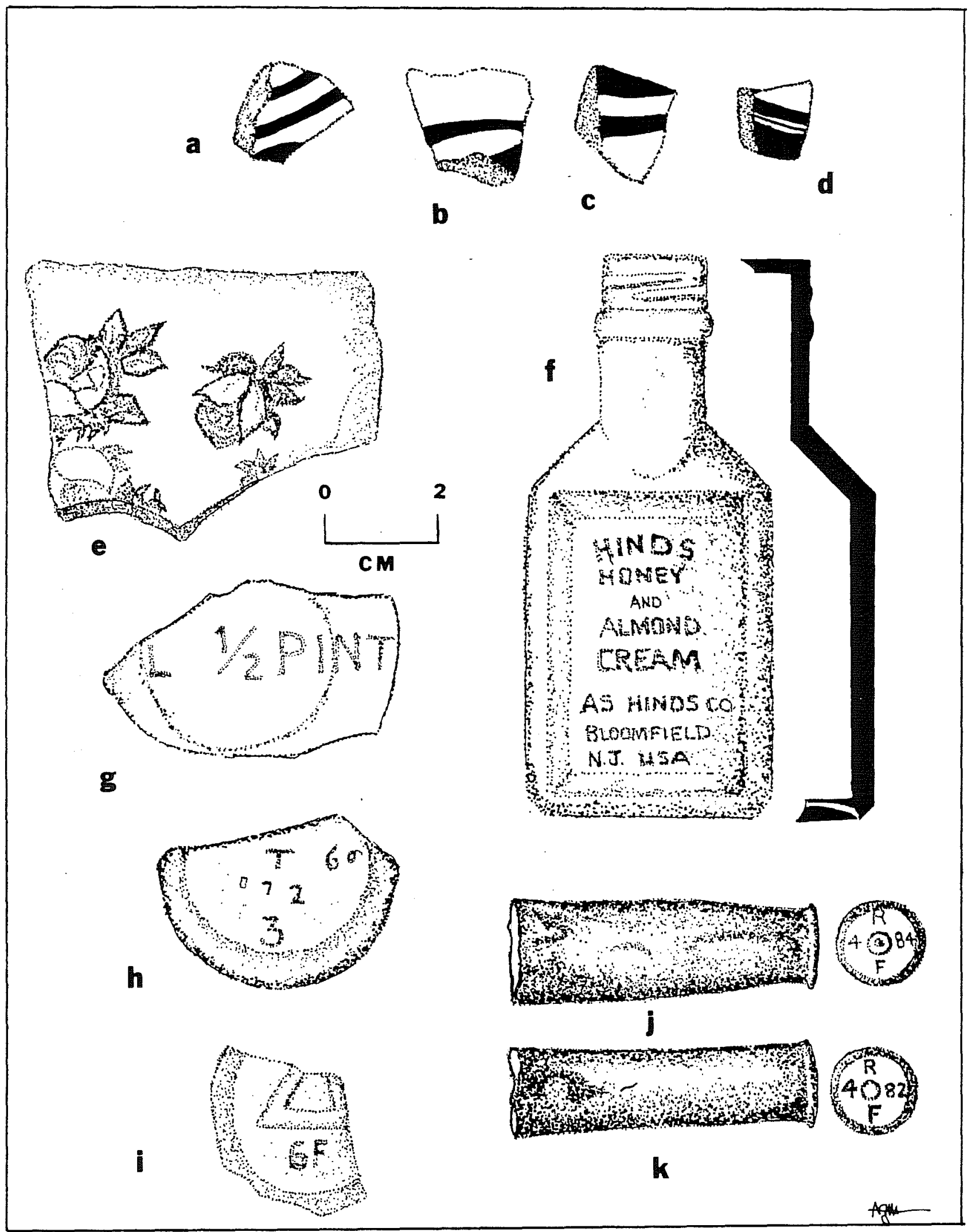

Figure 37. Collected Historic Materials. a-d, lead-glazed ware; e, decalcomania sherd; $f-j$, bottle fragments; $j-k$, cartridge casings. 
Three bullets, .30 caliber, 217 grains, full metal jacket, copper clad. Bullet diameter $73 \mathrm{~mm}$. L: 3.2 .

Several heavily corroded metal fragments were also recovered from Test Unit 3 at 41 WB 17, but were unidentifiable (see Site Descriptions, 41 WB 17).

Cartridge Cases (two specimens; 41 WB 13, uncontrolled surface collections)

Specimen 1; brass. L: 5.33; diameter of base: 1.54 .

Specimen 2; brass. L: 5.33; diameter of base: 1.49. Not fired.

These casings are thought to be late 19th-century $.45 / 70$ caliber cartridge cases and may date to 1881-1882 manufacture at the Frankfurt Arsenal, Pennsylvania. If so, they were intended for the military Model 1873 springfield rifle and carbine and may indicate past activities from Ft. McIntosh, Laredo.

\section{Burned Sandstone Rock Clusters}

As White (1980) has pointed out, burned rock clusters, or more generally, "hearths," have long been ignored in many archaeological analyses for a variety of reasons, none particularly plausible. Burned rock clusters are common occurrences in south Texas archaeology, and it is only recently that such characteristics as total weight and rock frequencies have been tabulated. The significance of burned rock clusters may lie in part in the variations of their makeup which reflect distinct cultural interests or activities.

Fourteen rock clusters were identified from subsurface contexts. These are provenienced in Figures 38 and 39 . Five rock features were observed in test units from features at 41 WB 13, four from 41 WB 15, four from 41 WB 17, and one from 41 WB 20.

Average weight of rock was considered a primary indicator of function. Weights are briefly summarized in Figure 38.

Figure 39 indicates several trends noted in excavated rock clusters. Ten of the features (over 70\%) contain 500 grams or less of burned sandstone materials. The other four clusters are larger and may indicate specific activities or functions. Interestingly, the average rock weight (total weight $\div$ total count) for the extremely large cluster no. 1 at 41 WB 13 is 1ittle different from the average rock weight found in smaller clusters at the same site.

This suggests a preference for a particular size of raw material.

Generally, all intrasite clusters are similar in size and weight, regardless of vertical provenience. This is particularly noticeable at 41 WB 17 (Fig. 39). Clusters at 47 WB 17 also show a slight decline in size as depth increases.

Characteristics of rock clusters at 41 WB 15 may be significant since the site is the only extensive occupation and/or multifunctional site investigated in the study area. It appears that the total number of rocks per cluster from the site is not necessarily related to the total weight of the feature. 


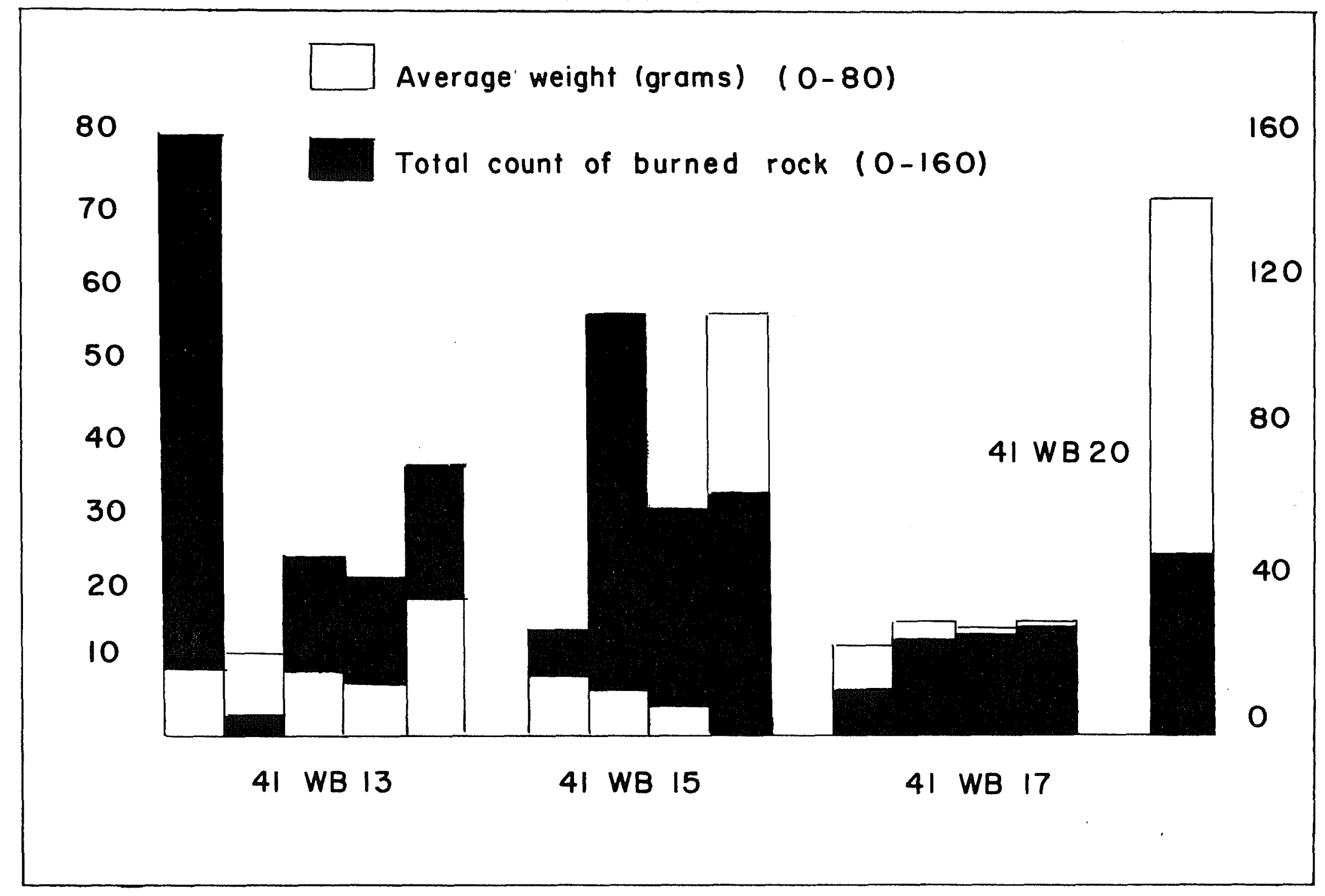

Figure 38. Total Count of Burned Rock Materials, by Site and Cluster. Histograms illustrate proportion of rock fragments to average weight. 


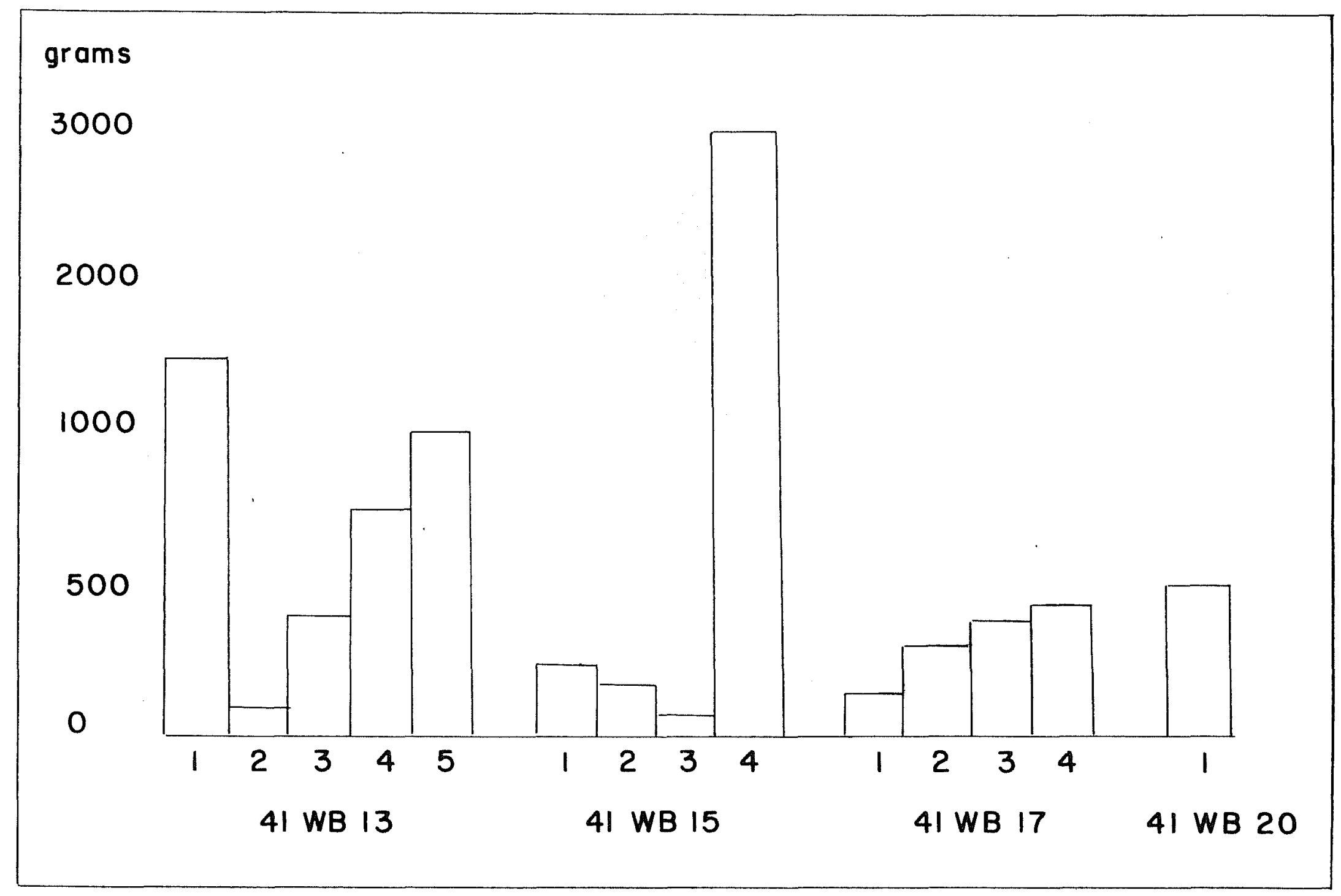

Figure 39. Total Weight of Burned Rock Materials, by Cluster. Weight tabulated in grams. 
Burned rock clusters 1 and 5 at 41 WB 13 and cluster 4 at 41 WB 15 appear to be larger activity centers, similar in some respects to the cluster at 41 WB 20. It should be noted that 41 WB 20 differs from other sites in that the associated cultural levels indicate only light to moderate prehistoric activities. The lack of smaller burned rock clusters throughout 41 WB 20 suggests that this site was a locality for specialized functions not requiring hearths, not only during (presumed) Late Prehistoric times but earlier as well.

Further interpretations of the limited rock cluster data are difficult because. of the small sample size and lack of associated chronologically diagnostic materials. It is apparent, however, that burned rock clusters reflect more intersite variation than intrasite variation. The total count and average rock weight per cluster are two criteria that may help to distinguish not only morphological but functional differences as well. Differences in total count and average weight may indicate the extent of usage as well as give a general indication of intensity of activity.

\section{SUMMARY OF INVESTIGATIONS}

A11 of the archaeological localities investigated within the Laredo Water Works project were located on the upper (tertiary) Holocene terraces above the Rio Grande at least $200 \mathrm{~m}$ or more from the modern river channel. Subsurface testing suggests that these occupation and/or multifunctional sites were linear and parallel to the river channel. The sites were typically more than $300 \mathrm{~m}$ in length but extended eastward, away from the water source, less than $200 \mathrm{~m}$. The unusually large size and general lack of subsurface or surface artifact concentrations imply a temporally long span of hunting and gathering activities in preferred occupation zones (cf. Hester 1980). These zones generally reflect meager cultural material and isolated clusters of burned rock, although distinctive layers of charcoal fragments and flecks were a common occurrence in most backhoe trench profiles.

Various charcoal layers, often little more than five centimeters thick, were traced in adjacent backhoe trenches for well over 50-100 $\mathrm{m}$ parallel to the terrace complexes. The same or similar layers were found westward, toward the river, but never eastward, away from the river. Whether these features are the reflection of prehistoric burn-offs or some other as yet unrecognized cause cannot as yet be determined. It should be noted that a major exception to the light to moderate activity at the sites was the extensive multifunctional site of 41 WB 15 . While much of the site had been destroyed or damaged by modern alterations, the margins of the occupation zone were still reasonably intact and were tested by hand and mechanical excavations. No charcoal layers were found below the surface in this locality, although the frequency and distribution of both surface and subsurface artifacts suggested substantial prehistoric activities. The presence of Shumla, Perdiz, Abasolo, Early Triangular, and other projectile point types suggests long-term interest in this location, perhaps related to its proximity to a high overlook above the river channel. Little is known of the character of past occupations because of the smal1 number of hand-excavated units and the widespread site disturbances. Excavated units do indicate at least moderate Late Prehistoric habitations, with a particular emphasis on finishing techniques on stone tools, as reflected by the extremely high debris count of tertiary 
flakes and chips in the upper excavated levels. Like many other areas of south Texas, the extensive occupation zone at 41 WB 15 is defined and delimited by natural topographic features and boundaries. The amount of 1 ight to moderate activity in sites adjacent to or near the Rio Grande may be in part because of specialized-function and/or satellite-activity localities associated with the main 1oci of occupation at 41 WB 15. It must be cautioned that this is only a speculative interpretation.

In the past, interpretations of the southern and southwestern Archaic cultures held that the entire area was long inhabited by a series of hunters and gatherers presumably represented by cultures of the Falcon and Meir Foci. Generally, the differences between these two depended upon the presence of Matamoros and Catán projectile points as late time markers and upon the absence of these projectile points in deeply buried sites. As Nunley (1971:390) points out, the definition of these foci has been vague and is basically unsuitable for anthropological explanations. In contrast, he has suggested that Archaic sites along the Rio Grande be redefined into several foci/component/assemblage units which are relevant to the current study area: (1) the Falcon unit, partially characterized by various projectile point types, including beveled Tortugas; (2) the Zapata unit, identified by Abasolo-Catán points and arrow points; (3) the Arroyo Velano unit, which includes Abasolo-Catán, Matamoros, and beveled triangular (Tontugas) points, with the bulk of the sites situated in what he described as lomera and mesa uplands; (4) the Santa Isabel unit, characterized by Langtry, Almagre, and Shumla projectile points; and (5) the Arroyo Gata unit, similar to the material culture of the Arroyo velano unit, but in mesa territories such as the Nueces River drainage.

Of these five cultural units, the Falcon unit is most similar to the Falcon focus, and both may represent the same culture that existed in the Laredo-Falcon area (Nunley 1971). Nunley saw a dependence upon riverine resources, proximity to the water source, and sites that reflect relatively sedentary occupations for collection of areal resources.

In 7 ight of our data, Nunley's broad interpretations of diagnostic projectile point types may compromise his cultural unit attributes, since the multicomponent nature of sites within the Laredo study area does not fit his speculation of cultural units occupying particular territorial and especially environmental niches (such as vega, lomera, mesa). Also, the subsistence pattern of Nunley's cultural units that are associated with environmental regions may not explain the predominance of mussel shell in buried deposits at multicomponent sites such as 41 WB 15, where a 11 components appear to be 1 inked to riverine resources. The presence of Late Prehistoric Perdiz points (associated with bison in other areas of south Texas) along the Rio Grande could reflect the movement of Perdizrelated peoples across southern Texas in response to seasonality or some other as yet unidentified factors. In this regard, Nunley's "units" do not clearly explain seasonality of occupation, but may, in fact, be a series of stopping places during a seasonal round.

Al1 cultural levels discovered in trench profiles appeared as existing on or within "contact zones" in otherwise homogeneous sands. These zones of leaching are presumed to represent living surfaces exposed for a while to natural 
weathering processes before being covered. Depths of deposits exceeded three meters. Paleo-Indian activities may exist below three meters (the standard working depth of the backhoe), but no evidence of this was found in any trenches in the study area.

Typically, the majority of projectile points collected from the study area are associated with the Archaic period, al though further distinctions within that span become vague, since several types are only generally defined (Abasolo, Catán, Early Triangular, etc.). Recent work in northeastern Mexico (Epstein 1980) suggests that the Catan point type may have existed much earlier than originally thought, and the whole series of varying-sized, convex-based projectile points similar to Abasolo may be related to any one of a number of different cultural sequences. With the exception of the Zorra-like projectile point and the square-shouldered point (Group 3, Form 1, page 52), all other artifacts are typical of southern Texas point collections. The large number of bifaces collected, primarily from $41 \mathrm{WB}$ 15, may indicate an extensive tool assemblage(s) involving a number of informal tools, as well as specifically manufactured composite tool forms.

The location of the burial sites at 41 WB 20 is significant in that the closest known occupation site, $41 \mathrm{WB} 15$, is more than a kilometer to the north. The burials appear to be isolated unless an undiscovered site is located just south of the arroyo complex. As noted earlier, seeds found with Burial 1 may be related to a disturbance or, possibly, may reflect a summer and/or fall interment. Since very few materials were associated with the burials (and no items from the Gulf coast), it is assumed that this may have been an inland hunting and gathering group. The large number of unidentified bird bones in the necklace and bracelet of Burial 1 may be of waterfowl. This may infer at least a seasonal emphasis on riverine resources.

A number of burials have been excavated in the interior of southern Texas, although relatively little detailed information has been gathered. Most of these burials have been single interments without associated artifacts (Cason 1952; Davis 1961; Hester 1964a, 1964b, 1969). The Cason burial was found at the Castillo site in Zapata County and included a large number of bone beads. In southern Texas, large cemetery sites are located along or adjacent to the coastline, while single burials are usually found inland (with the important exceptions of the burial sites of 41 BX 1 and 41 LK 27).

The archaeological investigations of the Laredo Water Works project have provided new insights into the complex picture of Rio Grande archaeology. Unfortunately, the frequency of disturbed sites and often the lack of chronologically associated materials have limited the value of some of the data presented in this report. More work is needed to clearly understand the first inhabitants of southern Texas and northeastern Mexico. It is only with a wider, more detailed data base that we can outline the cultural history of the early peoples who have left their mark on the prehistory of south Texas. 


\section{RECOMMENDATIONS}

Based on extensive field work and laboratory analysis of materials, no further work is recommended at any of the investigated sites within the project area. Although significant cultural remains were found within the vicinity of 41 WB 20 , it must be stressed that these remains were located outside the actual boundaries proposed for modification. Should additional remains be located at 41 WB 20 , they are assumed to be safe from damage, based on current plans and design proposals.

The pipeline route was extensively tested, and no significant cultural remains were found in any subsurface deposits along its length. The once major occupation site of 41 WB 15 is considered to have been critically damaged by erosion and modern alterations, although, as noted, no extensive subsurface deposits were identified along the route in this locality.

It must be stressed that, should modifications or changes occur in the proposed construction, particularly at site 41 WB 15 or in the vicinity of 41 WB 20 , proper authorities should be notified to assess potential cultural impact. Should any significant subsurface cultural deposits be uncovered during construction of the Laredo Water Works project, Laredo Water Works is urged to take proper steps to determine their importance. 


\section{ACKNOWLEDGMENTS}

Many individuals contributed time and expertise to this project, and their efforts significantly contributed to the successful conclusion of the work.

A. A. Perez, General Manager of the Laredo Water Works, gave his friendly cooperation throughout the operations. Aniceto Pardo expertly excavated backhoe trenches within the study area. R. Saunders and W. Gabriel of the Soil Conservation Service, USDA, Laredo, furnished soils information. Sister Yolanda of the Sacred Heart Children's Home gave her friendly cooperation to the project, as did many other landowners.

Special thanks must go to Hayden Whitsett and Daniel E. Fox, of the Texas Department of Water Resources, who coordinated the efforts of university and municipal personnel. Mr. Fox also furnished his expertise during investigations at 47 WB 20.

Dr. Anthony Coelho, Jr., of the Southwest Foundation for Research and Education, San Antonio, took time from his busy schedule to analyze skeletal materials from 41 WB 20. Glen Evans furnished geomorphological information.

Stephen Black successfully directed field operations throughout the study area. Courtenay Jones, Tom Miller, Cecil Peel, and Curtis Dusek of the CAR staff all worked under sometimes extremely adverse conditions without complaint. Beverly Van Note furnished advice and critical comments on the manuscript.

Dr. Thomas R. Hester, Director, and Jack Eaton, Associate Director of the CAR, furnished advice and encouragment throughout the project. Special thanks must also go to Sharon Quirk as editor, Patricia Wallace as draft typist, and Ann Young and Mary Lou Ellis as typists for the completed manuscript.

A final acknowledgment must be made to Al Wesolowsky who also critically edited this report and offered perceptive insights. His suggestions have contributed in no small part to the final work. 


\section{REFERENCES CITED}

Anderson, A. E.

1932 Artifacts of the Rio Grande Delta Region. Bulletin of the Texas Archeological and Paleontological Society 4:29-31.

Aveleyra Arroyo de Anda, L.

1951 Reconocimiento Arqueologico en La Zona de La Presa Internacional Falcon, Tamaulipas y Texas. Revistas Estudios Antropologicos 12:3159.

Bass, F. and T. R. Hester

1975 Archaeological Survey of Areas Slated for Modification, Laredo International Bridge II, City of Laredo, Texas. Center for Archaeological Research. The University of Texas at San Antonio, Archaeological Survey Report 14.

Betancourt, J.

1977 An Archaeological Survey of a Proposed Lignite Mine Area, Shel1 Rockdale South Lease, Milam County, Texas. Texas Historical Commission, Survey Report 21.

Blair, W. F.

1950 The Biotic Provinces of Texas. Texas Journal of Science 2(1):93175.

Brown, D.

1972 An Assessment of the Archaeological Resources to be Affected by Construction of Retamal International-Diversion Dam, United States Dike and Modified Hackney Floodway and Closure of Mission Floodway, Hidalgo County, Texas. Texas Archeological Survey, The University of Texas at Austin, Research Report 15.

Bryant, V. M., Jr.

1970 General Comment. Radiocarbon 12(2):625.

Campbe11, T. N.

1947 The Johnson Site: Type Site of the Aransas Focus of the Texas Coast. Bulletin of the Texas Archeological and Paleontological Society 18:40-75.

1960 Archeology of the Central and South Sections of the Texas Coast. Bulletin of the Texas Archeological and Paleontological Society 18:40-76. 
Campbe11, T.N. (continued)

1976 Venado Indians. In The Handbook of Texas: A Supplement, edited by E. S. Branda:1061. The Texas State Historical Association.

Campbe11, T. N. and T. J. Campbe11

1981 Historic Indian Groups of the Choke Canyon Reservoir and Surrounding Areas, Southern Texas. Center for Archaeological Research, The University of Texas at San Antonio, Choke Canyon Series 1.

Campbe11, W. and F. E. Ellis

1952 Artrisco Sites, Cochise Manifestations in the Middle Rio Grande Valley. American Antiquity 17:211-221.

Chambers, W. T.

1946 The Geography of Texas. The Steck Vaughn Co., Austin.

Cason, J. F.

1952 Report on Archeological Salvage in Falcon Reservoir, Season of 1952. Bulletin of the Texas Archeological Society 23:218-259.

Creel, D., A. J. McGraw, F. Valdez, Jr., and T. C. Kelly

1979 Excavations at 41 LK 106, A Prehistoric Occupation Site in Live Oak County, Texas. Center for Archaeological Research. The University of Texas at San Antonio, Archaeological Survey Report 62.

Davis, E. M.

1961 Report of a Burial. Texas Archaeology 5:4-5.

Dobie, J. F.

1929 A vaquero of the Brush Country. Southwest Press, Dallas.

Epstein, J. F.

1980 Some Reflections on the Nature of the Northeast Mexico Lithic Tradition and the Problem of its Origin. In Papers on the Prehistory of Northeastern Mexico and Adjacent Texas, edited by J. F. Epstein, T. R. Hester, and C. Graves:81-92. Center for Archaeological Research. The University of Texas at San Antonio, Special Report 9.

Fox, D. and $H$. Uecker

1978 An Archaeological Study of the McPherson Road Extension Project, Laredo, Texas. Center for Archaeological Research. The University of Texas at San Antonio, Archaeological Survey Report 45. 
Fox, D. and H. Whitsett

1979 An Archaeological Reconnaissance of the Laredo Water Quality Enhancement Project, Webb County, Texas. Letter report enclosed in letter of December 6, 1979, from E. Long to A. A. Perez.

Godden, G. A.

1971 The Illustrated Guide to Mason's Patent Ironstone and China and Related Wares. Praeger, New York.

Godfrey, C. and G. McKee

1973 Soil Map of Texas. Compiled by Texas A\&M University in cooperation with the Soil Conservation Service, USDA.

Ha11, G. D.

1973 Archeological Survey of Zacata Creek, Webb County, Texas. On file at the Texas Archeological Survey, The University of Texas at Austin.

Ha11, G. D., S. L. Black, and C. Graves

1982 Archaeological Investigations at Choke Canyon Reservoir, South Texas: The Phase I Findings. Center for Archaeological Research, The University of Texas at San Antonio, Choke Canyon Series 5.

Ha11, G. D. and K. Grombacher

1974 An Assessment of the Archeological and Historical Resources to be Affected by the Brazos Is land Waterway Project, Texas. Texas Archeological Survey. The University of Texas at Austin; Research Report 30.

Hartle, D. and R. Stephenson

1951 Archeological Investigations at the Falcon Reservoir, Starr County, Texas. Mimeographed report on file, Texas Archeological Research Laboratory, Austin.

Hester, T. R.

1964a Group Uncovers a Skeleton. The Peña Pow-Wow Newsletter, Carrizo Springs Archaeological Society 2(9):1-2.

1964b Two Dimmit County Skeletons Found. The Peña Pow-Wow Newsletter, Carrizo Springs Archaeological Society 2(1):2.

1968 Paleo-Indian Artifacts from Sites Along San Miguel Creek; Frio, Atascosa, and McMullen Counties, Texas. Bulletin of the Texas Archeological Society 39:147-162.

1969 Burial Practices in the Interior of Southern Texas, in Prehistoric Cemetery Sites. Bulletin of the Texas Archeological Society 40:159. 
Hester (continued)

1971 Archaeological Investigations at the La Jita Site, Uvalde County, Texas. Bulletin of the Texas Archeological Society 42:51-148.

1972a Toltec Artifacts from Southern Texas. Southwest Museum Masterkey $46(4): 137-140$.

1972b The Evidence for Prehistoric Trade on the Rio Grande Plain. In Archaeological Papers Presented to J. W. House, edited by T. R. Hester:21-25. Printed privately, Berkeley, California.

1972c The Surface Archaeology of Three Sites in Duval County, Texas. Lower Plains Archaeological Society Bulletin 2(1971):45-71.

1975a A Chronological Overview of Prehistoric Southern and South-Central Texas. Paper presented at the 1975 conference "The Prehistory of Northeastern Mexico and Texas," Monterrey, Mexico.

1975b Chipped Stone Industries on the Rio Grande Plain, Texas: Some Preliminary Observations. Texas Journal of Science 26(1-2):213-222.

1975c Archaeological and Historical Resources in the San Antonio-Guadalupe River Basins: A Prel iminary Statement. Center for Archaeological Research, The University of Texas at San Antonio, Regional Studies 1.

1976 Hunters and Gatherers of the Rio Grande Plain and Lower Coast of Texas. Center for Archaeological Research, The University of Texas at San Antonio.

1977 Archaeological Research at the Hinojosa Site (41 JW 8), Jim Wells County. Center for Archaeological Research. The University of Texas at San Antonio, Archaeological Survey Report 42.

1980 Digging Into South Texas Prehistory. Corona Publishing Company, San Antonio.

1981 Tradition and Diversity Among the Prehistoric Hunters and Gatherers of Southern Texas. Plains Anthropologist 26(92):119-128.

Hester, T. R. and M. Collins

1974 Evidence for Heat Treating of Southern Texas Projectile Points. Bulletin of the Texas Archeological Society 45:219-224.

Hester, T. R. and T. C. Hi11, Jr.

1971 An Initial Study of a Prehistoric Ceramic Tradition in Southern Texas. Plains Anthropologist 16(53):195-203.

1975 Some Aspects of Late Prehistoric and Protohistoric Archaeology in Southern Texas. Center for Archaeological Research, The University of Texas at San Antonio, Special Report 1. 
Hester, T. R. and H. J. Shafer

1975 An Initial Study of the Blade Technology on the Central and Southern Texas Coast. Plains Anthropologist 20(69):175-185.

Hester, T. R., L. White, and J. White

1969 Archaeological Materials from the Oulline Site and Other Sites in LaSalle County, Texas. Texas Journal of Science 21(2):130-165.

Holdsworth, J.

1972 A Study of Modern Flora and Fauna in the Vicinity of the Holdsworth Site (4I ZV 14). Appendix 1 in Prehistoric Occupation at the Holdsworth and Stewart Sites on the Rio Grande Plain of Texas, by T. R. Hester and T. C. Hi11, Jr.:65-73. Bulletin of the Texas Archeological Society 43:65-73.

Ivey, J. E., T. Medlin, and J. D. Eaton

1977 An Initial Archaeological Assessment of Areas Proposed for Modiification at Fort McIntosh, Webb County, Texas. Center for Archaeological Research. The University of Texas at San Antonio, Archaeological Survey Report 32.

Jackson, A. T.

1940 Tubutar Pipes and Other Tubes in Texas. Bulletin of the Texas Archeological and Paleontological Society 12:99-137.

Jelks, E. B.

1952 The River Basin Surveys, Archaeological Salvage Program in Texas. Texas Journal of Science 4(2):131-138.

1953 The River Basin Surveys: Recent Archaeological Investigations in Texas, Arkansas, and Kansas. Texas Journal of Science 5(3):342-347.

1975 The Use and Misuse of Random Sampling in Archaeology. Jett PubTishing, Normal, Illinois.

Johnson, $E$.

1931 The Natural Regions of Texas. The University of Texas Bulletin 3113, Bureau of Business Research Monograph 8.

Johnson, L. R., Jr.

1964 The Devil's Mouth Site: A Stratified Campsite at Amistad Reservoir, Val Verde County, Texas. Department of Anthropology. The University of Texas at Austin, Archeology Series 6. 
Kelley, J. C.

1947 The Cultural Affiliations and Chronological Position of the Clear Fork Focus. American Antiquity 13(2):97-109.

Krieger, A. and J. Hughes

1950 Archeological Salvage in the Falcon Reservoir Area: Progress Report 1. Mimeographed, Texas Archeological Research Laboratory, Austin.

Lynn, W., D. Fox, and N. O'Malley

1977 Cultural Resource Survey of Choke Canyon Reservoir, Live Oak and McMullen Counties, Texas. Texas Historical Commission, Archeological Survey Report 20.

MacNeish, R. S.

1947 A Preliminary Report on Coastal Tamaulipas. American Anthropologist 13(1):1-15.

1958 Preliminary Archaeological Investigations in Sierra de Tamaulipas, Mexico. Transactions of the American Philosophical Society 48:6.

Ma11ouf, M.

1975 Three Rivers Flood Protection Project, Live Oak County, Texas: An Archeological and Historical Survey of Areas Proposed for Modification. Report to the Fort Worth District Corps of Engineers by the Texas Archeological Survey, The University of Texas at Austin.

Mallouf, M., R. B. Baskin, and K. Killen

1977 A Predictive Assessment of Cultural Resources in Hidalgo and Willacy ${ }^{-}$ Counties, Texas. Texas Historical Commission, Archeological Survey Report 23.

Mankowitz, W. and R. Hagger

1957 The Concise Encyclopedia of English Pottery and Porcelain. Hawthorn Books, Inc., New York.

Martin, P. S., J. B. Rinaldo, E. Bluhm, H. C. Cutler, and R. Grange

1952 Mogollon Cultural Continuity and Change: The Stratigraphic Analys is of Tularosa and Cordova Caves. Fieldiana Anthropology 40. Chicago Natural History Museum, Chicago.

Newton, M. B., Jr.

1968 The Distribution and Character of Sites, Arroyo Los 01mos, Starr

County. Bulletin of the Texas Archeological Society 38(18):18-24. 
Nunley, J.P.

1971 Sociocultural Units of the Southwestern Texas Archaic: An Analytical Approach. Ph.D. dissertation, Southern Methodist University. University Microfilms.

Nunley, J. P. and T. R. Hester

1975 An Assessment of Archaeological Resources in Portions of Starr County, Texas. Center for Archaeological Research. The University of Texas at San Antonio, Archaeological Survey Report 7.

Peavy, W. G.

1971 Letter dealing with archaeological sites on Chacon Creek, Webb County, Texas. On file, Texas Archeological Research Laboratory, Austin.

Prewitt, E.

1974 Preliminary Archeological Investigations in the Rio Grande Delta Area of Texas. Bulletin of the Texas Archeological Society 45:5565.

Raycraft, D. and C. Raycraft

1975 American Country Pottery. Wallace-Homestead Book Co., Des Moines, Iowa.

Redman, C.

1974 Archaeological Sampling Strategies. Addison-Wesley Module in Anthropalogy 55 .

Richardson, R. H.

1980 Screw Worms and Longhorns, Brush and Fire. Texas Academy of Science News 5(2):10-11.

Schuetz, M.

1969 The History and Archeology of Mission San Juan Capistrano, San Antonio, Texas, Vol. II. State Building Commission, Archeological Program, Report 11.

Scurlock, D., A. Benavides, Jr., D. Isham, and J. Clark, Jr.

1976 An Archeological and Historical Survey of the Proposed Mission Parkway, San Antonio, Texas. Texas Historical Commission, Archeological Survey Report 17. 
Shafer, H. J. and T. R. Hester

1971 A Study of the Function and Technology of Certain Bifacial Tools from Southern Texas. Texas Historical Commission, Office of the State Archeologist, Report 20.

Shepard, A. 0.

1976 Ceramics for the Archaeologist. Carnegie Institute of Washington, Publication 109.

Shimer, J. A.

1972 Field Guide to Land Forms in the United States. The Macmillan Co., New York.

Shiner, J. L.

1969 Component Analysis for Archaic Sites. Bulletin of the Texas Archeological Society 40:215-229.

Spence, $M$.

1971 Mesoamerican Studies 8: Some Lithic Assemblages of Western Zacatecas and Durango, Mexico. University Museum, Southern I17inois University, Carbondale, Illinois.

Story, D. A.

1980 Adaptive Strategies of Archaic Cultures of the West Gulf Coast Plain. Unpublished manuscript on file, Center for Archaeological Research, The University of Texas at San Antonio.

Suhm, D. A.

1960 A Review of Central Texas Archeology. Bulletin of the Texas Archeological Society 29:63-107.

Suhm, D. A. and E. Jelks

1962 Handbook of Texas Archeology: Type Descriptions. Texas Archeological Society, Special Publication 1 and Texas Memorial Museum, Bulletin 4.

Suhm, D. A., A. Krieger, and E. Jelks

1954 An Introductory Handbook of Texas Archeology. Bulletin of the Texas Archeological Society 25.

Thornbury, $W$.

1965 Regional Geomorphology of the United States. John Wiley and Sons, Inc., New York. 
Thornwaite, C. W.

1948 An Approach Toward a Rational Classification of Climate. Geographical Review 38:55-94.

Weir, F.

1956 Surface Artifacts from La Perdida, Starr County, Texas. Bulletin of the Texas Archeological Society 27:59-78.

White, $J$.

1980 A Closer Look at Clusters. American Antiquity 45:66-73. 